\title{
Development of Trade Relations Between Mexico and China Under Non-Bilateral Trade Treaties
}

\author{
Paola Barrera Ibarra
}

\begin{abstract}
The Diplomatic relations between Mexico and the People's Republic of China were established on February 14, 1972, after the Mexican government joined in October 1971 to vote in favor of the Asian country joining the United Nations as sole representative of that nation and accepting the principle of "one China" based on the recognition of the indivisibility of its territory. Even though China and Mexico have not signed any Free Trade Agreement, economically speaking China is today the second largest commercial partner of Mexico in the world and the third global destination of Mexican exports. Under the Mexico-China Comprehensive Strategic Association, agreements have been generated that have improved Mexico's access to the Chinese market. Still the bilateral trade balance between these two countries has been in deficit for Mexico, especially as a result of the push achieved by the PRC after joining the World Trade Organization.This research attempts to analyses the trade relationship between Mexico and China in the context SWOT analysis, that it, from the strengths, weaknesses, opportunities and threats such partnership has, also analyses whether or not this two nations are strategic partners, as well as whether or not their economies reflect any benefit as a consequence of their trade activity. At the end of this research, it was found that Mexico's trade exchange with China has not opened real opportunities for Mexican foreign trade, and therefore has not managed to become a key factor in the growth of the Mexican economy, which partly is due to the deficit reported by México, which show that commercial exchange has not been equitable between the two parties.
\end{abstract}

Keywords: China and Mexico trade relationship, Mexican Trade, Chinese Trade

\section{INTRODUCTION}

\section{A. Research Significance}

The subject at hand is of great importance in the field of International Relations, and in particular, in the study of Mexican Foreign Trade, in the first case, because it is directly related to the flows (imports and exports) of international trade, referring in this case to two main players: Mexico and China. Even though China is still a developing country, it also the second largest economy in the world and is rapidly advancing on the path of being the largest. While its share in the world economy was $1.8 \%$ in 1978 , in 2017 it rose to $18.7 \%$, it is the country that has the world's most foreign currency reserve with 3.12 trillion. In 2018 China, which grew by $6.6 \%$, in 2050 is expected to have only $20 \%$ of the gross domestic product income produced in the world. It is estimated that this proportion will be followed by India and the US is in third position. Therefore, it is extremely important for the studies of International Relations research about the relationship between China and Mexico, especially because today China is the second commercial partner of Mexico in the world and the third global destination of Mexican exports, and these two partners have not even signed any Trade Agreement as Mexico has done it with countries like USA and Japan.

Revised Manuscript Received on June 13, 2020.

* Correspondence Author

Paola Barrera Ibarra*, Law Degree, National Autonomous University of Mexico. Email address: barrera.paola@qq.com

(c) The Authors. Published by Blue Eyes Intelligence Engineering and Sciences Publication (BEIESP). This is an open access article under the CC BY-NC-ND license (http://creativecommons.org/licenses/by-nc-nd/4.0/)
Indeed, and knowing the importance of international trade in the economic growth of that country that manages to insert a global economy with proven international competitiveness, the intention is to investigate until which point the relationship with China has created new opportunities for Mexico's foreign trade. Not without first remembering that Mexico, like other Latin American countries, experienced economic crises in the 1980s and 1990s that resulted in a significant loss of its international competitiveness.

\section{B. Comments on Literature Review}

Regarding the Chinese and Mexican literature in terms of trade between these two countries, it is true that some studies have been conducted in this regard; however, there are still problems that have not been fully addressed or simply have not been treated by the academy, as well as by the foreign policies of the countries involved. So from the previous analysis the following problems are the ones still unfinished or unresolved and they can be highlighted:

First: The lack of a political-commercial strategy in order to diversify sales from Mexico to China, stimulate business alliances, and strengthen commercial and technological exchange, to be attractive in joint innovation projects. The Mexican market could produce products made in Mexico with Chinese inputs that would contribute to improving the current account balance with that country, and it would be obtained a win-win scheme.

Second: Lack of analysis and evaluation regarding whether the policy established by Mexico has favored it, or whether the real winner has been China. The lack of study on a possible Free Trade Agreement between Mexico and China to know if it would be advantageous or not to reduce the deficit that Mexico has with respect to China, it is necessary to take advantage of the economic reordering that China is experiencing, as well as its interest in Latin America, in order to not face a direct competitor, but to find in China a commercial ally, with whom facilities are identified to take advantage of Mexican products. It is important to emphasize that the competent authorities regarding the investment and trade opening decisions of Mexico are the ones that must generate the conditions of a competitive and fair market, without being completely armored or afraid of this threat, but rather seeing the presence of China in positively, as an opportunity for growth.

Third: Mexico is not familiar with the Chinese market, the lack of bilateral Mexico-China cooperation is essential, since there is no free trade agreement and even so certain agricultural products are managing to penetrate the Chinese market by way of cooperation such as avocado, blackberry and raspberry.

Published By:

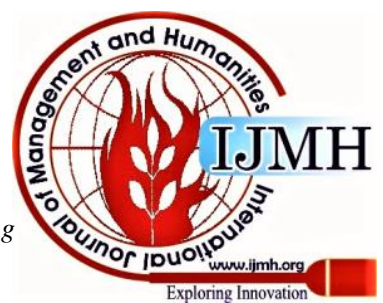




\section{Development of Trade Relations Between Mexico and China Under Non-Bilateral Trade Treaties}

Other products such as tequila have achieved some penetration, but some types, such as reposed, still find limitations. Furthermore, given that China has great differences between its regions, it is necessary to achieve a better dialogue at the regional level, and it is evident that this requires strategic planning in order to know where there are scarce products that Mexico could promote and study deeper China, its opportunity areas, conditions and its business culture. In summary, without renouncing its privileged economic relationship with the United States, Mexico has to decipher China in strategic terms and improve its level of dialogue with the second great power in the world, since it consolidates rapidly as the hegemonic country of Asia, and the Mexican economy requires participation in it to continue advancing.

\section{Research methods}

The methods used in this research were mainly two, the SWOT analysis and the comparative method, and indirectly the hypothetical-deductive method. The SWOT (strengths, weaknesses, opportunities, and threats) analysis is a framework used to evaluate a country's competitive position and to develop strategic planning. Through SWOT analysis the research has assessed to internal and external factors, as well as current and future potential. The SWOT analysis is designed to facilitate a realistic, fact-based, data-driven look at the strengths and weaknesses of the countries relationship, its initiatives and policies. During this analysis, data from international entities such as the World Trade Organization was used, as well as the national official websites from Mexico and China, in order to have internal and external data that lead to a more accurate analysis.

Likewise, throughout this research, the comparative method was used, which is defined as a systematic research procedure, based on the differentiation of phenomena, with the intention of establishing similarities and differences between them. As a result, it aims to obtain data that leads to the definition of a problem, the understanding of it and even the search for possible improvements, as was the case when comparing international trade between Mexico and China, comparing the behavior that their economics have had over the last twenty years, as well as their achievements and challenges. Comparison is an effective method of putting tacit knowledge and tacit attitudes into practice. This is possible by demonstrating in parallel two objects or situations with slight differences and explaining the differences between them, in this case the players were China and Mexico.

The hypothetical-deductive method (HD) which was indirectly used in this research is a methodological procedure that consists of taking some assertions as hypotheses and testing these hypotheses, deducing from them, together with knowledge that is already known, conclusions that are confronted with the facts. This procedure is an important part of the methodology of science; its application is linked to various methodological operations: confrontation of facts, revision of existing concepts, and formation of new concepts and reconciliation of hypotheses with other theoretical propositions. Through this method the reasoning involved started with a general theory of all possible factors that might affect the outcome; then deductions were made from that hypothesis to predict what might happen at the end of this research. In researching inquiry, reasoning is very important because, in order to solve science problems, it is necessary to make hypotheses. Many hypotheses cannot be tested directly; you have to deduce from a hypothesis and make predictions which can be tested through the analysis of the obtained outcomes. That is what happened in this case.

\section{II.CURRENT SITUATION OF CHINESE AND MEXICANT TRADE}

\section{A. Status of the Mexico's Trade: Imports and Exports}

Mexican economy is an open economy since the 1980s, which has gradually been integrated into global markets through unilateral opening, through Mexico's membership in General Agreement on Tariffs and Trade (GATT) in August 1985, to the World Trade Organization (WTO) in January 1995, and through the construction of a network of free trade agreements.

Since Mexico entered the trade opening scheme, the country's trade and economic policies have been oriented to favor the performance of the external sector; but it was after the signature of NAFTA $2.0^{1}$ when the importance of the behavior of the external sector to generate national economic growth has become more notable. It is so because what Mexico has been looking to carrying out in its external sector is 1)remove obstacles to trade and facilitate the crossborder movement of goods and services; 2) promote fair competition conditions in the free trade zone; 3) substantially increase investment opportunities; 4) protect and enforce, properly and effectively, intellectual property rights; 5) create effective procedures for the application and fulfillment of the Treaty, for its joint administration and for the resolution of controversy; and 6) establish guidelines for further bilateral, trilateral, regional and multilateral cooperation aimed at expanding and improving the benefits of this Agreement.

\section{B. Mexico Trade Market Share}

Thus, this has been the general scenario in which Mexico has perform as international player, having in mind that there have been ups and downs for Mexico in its internal and external economy, today Mexico is the $15^{\text {th }}$ largest economy of the world and the $2^{\text {nd }}$ in Latin America. In 2018, reviewed in 2019, Mexico was rank by the WTO as the $12^{\text {th }}$ leading exporter and importer in world merchandise trade, while considering the European Union as one economic entity, Mexico was also ranked by WTO as the $7^{\text {th }}$ leading merchandise exporter and as the $8^{\text {th }}$ leading merchandise

\footnotetext{
${ }^{1}$ In April 1990 President Salinas sent a commission to the United States to explore the possibility of signing a Free Trade Agreement with that nation. The US authorities agreed and the negotiations began. Canada decided to join the negotiations because it already had a free trade agreement signed with the United States, so it became a trilateral agreement, called the North American Free Trade Agreement (NAFTA), today called United States Mexico and Canada Agreement (USMCA or NAFTA 2.0).
}

Published By:

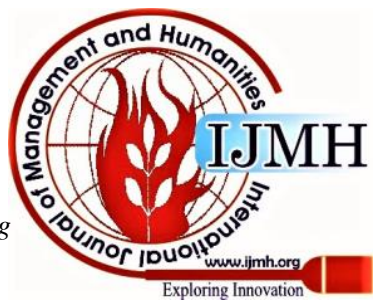


importer, leaving behind Canada, Russia, Singapore, United Arabs Emirates, Taipei, India, Switzerland, Saudi Arabia and some more.

\section{Leading exporters and importers in world merchandise trade, 2018} (Billion dollars and percentage)

\begin{tabular}{|c|c|c|c|c|c|c|c|c|c|}
\hline Rank & Espoters & Value & Share & $\begin{array}{c}\text { Annual } \\
\text { perconamo } \\
\text { change }\end{array}$ & Rank & Imponters & |Value & Share & $\begin{array}{c}\text { Annual } \\
\text { percontage } \\
\text { change }\end{array}$ \\
\hline 1 & China & 2487 & 12.8 & 10 & 1 & United Stateses of Ameica & 2614 & 13.2 & 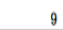 \\
\hline 2 & Uniled States of America & 1664 & 8.5 & 8 & 2 & Chima & 2136 & 10.8 & 16 \\
\hline 3 & Germany & 1561 & 8.0 & 8 & 3 & Germany & 1286 & 6.5 & 11 \\
\hline 4 & Japan & 738 & 3.8 & 6 & 4 & Japan & 749 & 3.8 & 11 \\
\hline 5 & Netherlands & 723 & 3.7 & 11 & 5 & United Kingdom & 674 & 3.4 & \\
\hline 6 & Korea, Republic of & 605 & 3.1 & 5 & 6 & France & 673 & 3.4 & \\
\hline 7 & Frances & 582 & 3.0 & 9 & 7 & Nethelands & 646 & 3.3 & 12 \\
\hline \multirow[t]{3}{*}{8} & Hong Kong, China & 569 & 29 & 3 & 8 & Hong Kong, China & 628 & 3.2 & 6 \\
\hline & Domestic expots & 13 & 0.1 & 30 & & Retained imports (1) & 155 & 0.8 & 12 \\
\hline & Reerpots & 556 & 2.9 & 5 & & & & & \\
\hline 9 & Italy & 547 & 28 & 8 & 9 & Korea, Repubilic of & 535 & 2.7 & 12 \\
\hline 10 & United Kingdom & 486 & 2.5 & 10 & 10 & India & 511 & 2.6 & 14 \\
\hline 11 & Belgum & 467 & 24 & 8 & 11 & laly & 501 & 25 & 11 \\
\hline 12 & Mexico & 451 & 23 & 10 & 12 & Mexico & 477 & 2.4 & 10 \\
\hline 13 & Canada & 450 & 23 & 7 & 13 & Canada (1) & 469 & 24 & 6 \\
\hline 14 & Russinn Foderation & 444 & 23 & 26 & 14 & Begum & 450 & 23 & 10 \\
\hline \multirow[t]{3}{*}{15} & Singappore & 413 & 2.1 & 11 & 15 & Spain & 388 & 2.0 & 10 \\
\hline & Domestic exports & 209 & 1.1 & 11 & & & & & \\
\hline & Reerports & 203 & 1.0 & 10 & & & & & \\
\hline \multirow[t]{2}{*}{16} & United Arab Emirates (1) & 346 & 1.8 & 10 & 16 & Singapore & 371 & 1.9 & 13 \\
\hline & & & & & & Retained imports (1) & 167 & 0.8 & 17 \\
\hline 17 & Spain & 345 & 1.8 & 8 & 17 & Chinese Taipei & 286 & 1.4 & 10 \\
\hline 18 & Chineses Tapei & 336 & 1.7 & 6 & 18 & Switereland & 279 & 1.4 & 4 \\
\hline 19 & India & 326 & 1.7 & 9 & 19 & Poland & 267 & 13 & 14 \\
\hline 20 & Switereland & 311 & 1.6 & 4 & 20 & Uniled Aab Emirates (1) & 253 & 1.3 & 6 \\
\hline 21 & Saudi Arabia Kingdom of 1 & 299 & 1.5 & 35 & 21 & Thaland & 250 & 1.3 & 13 \\
\hline
\end{tabular}

Leading exporters and importers in world merchandise trade (excluding intra-EU (28) trade), 2018 (Billion dollars and percentage)

\begin{tabular}{|c|c|c|c|c|c|c|c|c|c|}
\hline Rank & Eponters & Value | & Share & $\begin{array}{c}\text { Annual } \\
\text { percomage } \\
\text { change }\end{array}$ & Rank & Importers & Value & Share & \begin{tabular}{|c|} 
Anuulal \\
percontage \\
change
\end{tabular} \\
\hline 1 & China & 2487 & 16.2 & 10 & 1 & United States of Amenica & 2614 & 16.6 & 9 \\
\hline 2 & EtraEUU (28) eppots & 2309 & 15.1 & 9 & 2 & ExtraEU (28) imports & 2337 & 14.9 & 11 \\
\hline 3 & United States of Amenica & 1664 & 10.9 & 8 & 3 & China & 2136 & 13.6 & 16 \\
\hline 4 & Japan & 738 & 4.8 & 6 & 4 & hapan & 749 & 4.8 & 11 \\
\hline \multirow[t]{2}{*}{5} & Korea, Republic of & 605 & 3.9 & 5 & 5 & Hong Kong, China & 628 & 4.0 & 6 \\
\hline & & & & & & Retained imports (1) & 155 & 1.0 & 12 \\
\hline \multirow[t]{3}{*}{6} & Hong Kong, China & 569 & 3.7 & 3 & 6 & Korea, Republic of & 535 & 3.4 & 12 \\
\hline & Domestic exponts & 13 & 0.1 & .30 & & & & & \\
\hline & Reexponts & 556 & 3.6 & 5 & & & & & \\
\hline 7 & Mexico & 451 & 2.9 & 10 & 7 & India & 511 & 3.3 & 14 \\
\hline 8 & Canada & 450 & 2.9 & 7 & 8 & Merico & 477 & 3.0 & 10 \\
\hline 9 & Russian Federation & 444 & 2.9 & 26 & 9 & Cannada (1) & 469 & 3.0 & 6 \\
\hline \multirow[t]{3}{*}{10} & Singapore & 413 & 27 & 11 & 10 & Singappore & 371 & 2.4 & 13 \\
\hline & Domestic exports & 209 & 1.4 & 11 & & Retained imports (1) & 167 & 1.1 & 17 \\
\hline & Reerports & 203 & 1.3 & 10 & & & & & \\
\hline 11 & United Aab Eminates (1) & 346 & 23 & 10 & 11 & Chinese Taipei & 286 & 1.8 & 10 \\
\hline 12 & Chineses Taipei & 336 & 2.2 & 6 & 12 & Switeeland & 279 & 1.8 & 4 \\
\hline 13 & India & 326 & 2.1 & 9 & 13 & Uniled Aab Eminates (1) & 253 & 1.6 & 6 \\
\hline 14 & Switzerland & 311 & 2.0 & 4 & 14 & Thailand & 250 & 1.6 & 13 \\
\hline 15 & Saudi Arabia, Kingdom of (1) & 299 & 20 & 35 & 15 & Russin Foderation (2) & 249 & 1.6 & 5 \\
\hline
\end{tabular}

As it is observed in the tables above, if the European Union is consider as a trade partner, the Mexico holds a market share of 2.9 as exporter of merchandise and a market share of 3.0 as merchandise importer, having an annual percentage change of ten and fourteen, respectively. Likewise, when it comes to merchandise trade, imports and exports, Mexico is the leader in Latin America Region surpassing the largest economy in the region by twelve and thirteen passions in the world ranking, which does not happen with commercial services trade, but still this position proofs the importance that international trade has in Mexican economy and that Mexico is an important platform in the international scenario, especially regarding merchandise trade.

In terms of commercial services, today Mexico occupies the number 40th as a leading exporter and the number 32nd as a leading importer, having less than $1 \%$ of the world market share, which is $0.5 \%$ and $0.7 \%$ respectively with an annual change of 5 and 1. But then again, if the European Union is consider as an only one trade entity then, Mexico occupies the number $23^{\text {rd }}$ as leading exporter and as the number $20^{\text {th }}$ as importer, both still in commercial service, where its annual change remain and its participation in the market share grows to 0.7 and 0.9 respectively, but still not even reaching $1 \%$.

\section{Mexico Main Trade Partners}

In April 1990 Mexico started to build its trade partnership network when President Salinas sent a commission to the United States to explore the possibility of signing a Free Trade Agreement with that nation. The US authorities agreed and the negotiations began. Canada decided to join the negotiations because it already had a free trade agreement signed with the United States, so it became a trilateral agreement, called the North American Free Trade Agreement (NAFTA).

On the other hand, it was in 2003 when China became the second largest trade partner while Mexico has the same position for China in Latin America region, just after Brazil. China has been seen by Mexico as a new market to diversify its trade activity and not highly depend on US, which currently is the main trade partner of Mexico. Nevertheless, such diversification has net been achieved, mainly, due to the main deficit that Mexico is having with China, so even though US and China are the most important trade partners of Mexico, with the first one, Mexico has a surplus, with China has a deficit.

Since Mexico entered the trade opening scheme, the country's trade and economic policies have been oriented to favor the performance of the external sector; but it was after the signature of NAFTA when the importance of the behavior of the external sector to generate national economic growth has become more notable (Carrillo, 2001). In 2018, being the latest data available in the World Trade Organization, Mexican exports mainly go to countries form North America, Asia, Europe and Latin America, specifically from North America to America and Canada, which is explained due to the existing Free Trade Agreement that these three countries have signed. Mexican exports are highly concentrated in The United States, who received 344,602 US million dollars, representing $76.5 \%$ of Mexican exports likewise, Canada received 24,707 US million dollars of Mexican exports, representing 3.1\%. In the third place, from Asia country, China received 14,065 US million dollars, representing 1.6\%; while Germany and Brazil received equally $1 \%$ of Mexican exports

\section{Mexican Exports Destinations}

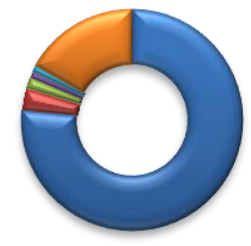

$\square$ US $\square$ Canada $\square$ China $\square$ Germany $\square$ Brazil $\square$ Others

Source: World Trade Organization

Published By:

Blue Eyes Intelligence Engineering \& Sciences Publication

(C) Copyright: All rights reserved.

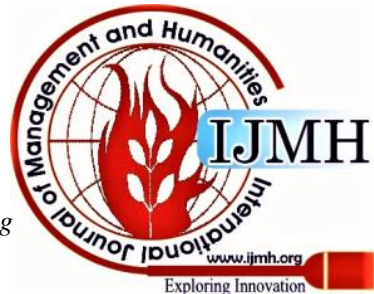


For the same period, Mexico imported products from almost the same trade partners, from the United States received 216, 282 US million dollar, which represented $46.6 \%$ of total Mexican imports; from its second largest trade partner received 83,505 US million dollars, which represented 18\% of Mexican market; in the third place Japan reached 18,193 US million from its exports to Mexico, which represented $3.9 \%$ of Mexican imports; in the fourth place was again Germany with 17,761 US million dollars representing 3.8\% of the Mexican imports and finally within the top 5 Mexican import destination South Korea occupied $3.6 \%$ of the Mexican market with 16,727 US million dollars.

\section{Main Import Partners}
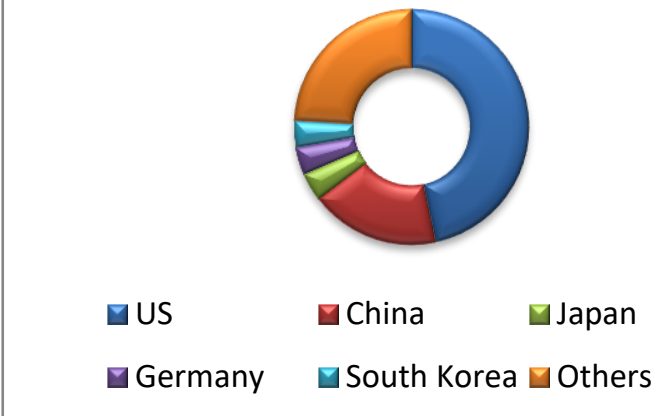

Source: World Trade Organization

There is no doubt that United States and China compete for the Mexican market but under different situation, that is, America has a Free Trade Agreement with Mexico, which entitled these two partners of preference in their trade circumstances while China has only signed certain bilateral agreements. Furthermore, under article 32.10 of The United States-Mexico-Canada agreement (USMCA), in Chapter 32 Mexico and Canada would not have the possibility of reaching a trade agreement with China since the United States would prevent it. That is so since in the Chapter 32 of Exceptions and General Provisions article 32.10 refers that if one of the three partners (United States, Mexico or Canada) wishes to initiate a trade agreement with a "nonmarket" country (not favorable to free trade) must notify the partners three months before starting their negotiations, indicating that "The Party shall provide as much information as possible about the objectives of those negotiations" 2 .

The article 32.10 is not a specific provision to prevent other countries from accessing the US market through the back door (Canada or Mexico), instead it is a veto power to Washington, because this concession threatens the sovereignty of Mexico to trade freely with China and could serve as a model for other trade agreements where any other trade partner could insert similar clauses, which would reinforce the US strategy to contain China as commercial competitor.

\section{Mexico Commodities Trade}

Mexico is highly dependent on foreign trade, which represented 77.6\% of its GDP in 2018 (World Bank, latest available data). The country mainly exports manufacture products such as TV's, automobiles with reciprocating piston engine and in general vehicles, their parts and automatic data processing machines, representing $81.2 \%$ of Mexican exports. The second group of Mexican commodities exported by Mexico represents $8.3 \%$ and it includes fuel and mining products such as petroleum oils and oils obtained from bituminous. The third group of commodities according to its proportion is the agricultural sector, which represents $8.1 \%$ of the total Mexican exports, in this section, products such as beer, diverse type of chilies, tomatoes, avocado, blackberries, bananas and other fruits and vegetables are the ones exported. The remaining $2.4 \%$ is a combination of different commodities with a very low presence in the international market, so it does not have an absolute or comparative advantage in those other commodities.

The Mexican agricultural sector was dramatically affected by the ratification of the NAFTA, because after its implementation, the Foreign Direct Investment coming primarily from United States has been target at manufactures, especially the automobile industry and mostly concentrated in towns neighboring the U.S border where many assembly factories are located as well as in the capital city.

\section{Mexican Exported Commodity Group}

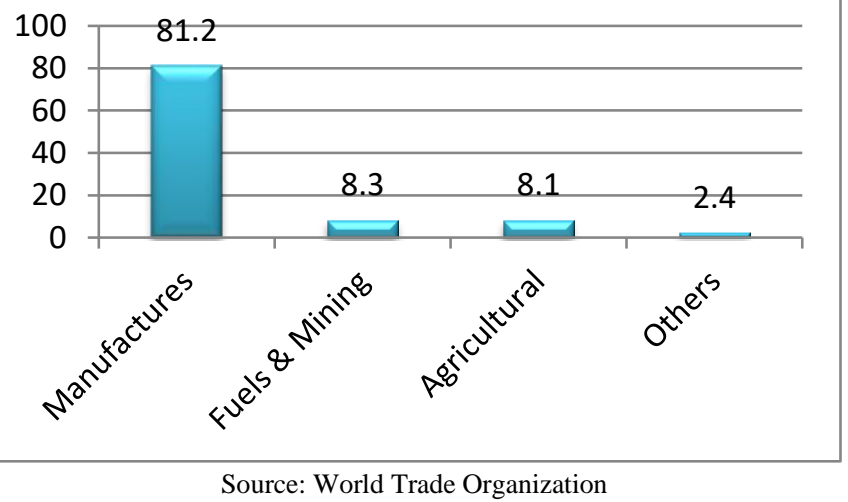

As for imports, Mexico's main purchases are within the same groups that its exports, thus manufacture products is the largest group, which includes parts and accessories of automatic data process, monolithic integrated circuits, telegraphic apparatus and Storage units; representing 78.6\% of the Mexican imports. After the manufacture group, the second largest group corresponds to fuels and mining, representing $10.8 \%$ and in which petroleum oils takes place. In this regard, although Mexico through the history of the oil industry once was one of the main producers in the world, today the national production has fallen due to the exhaustion of Cantarell ${ }^{3}$, Mexico is outside the top ten of the producers of Oil, the world leader according to the most current data is the United States, Russia and Saudi Arabia, which have an infrastructure that allows them to extract more than ten million barrels per day.

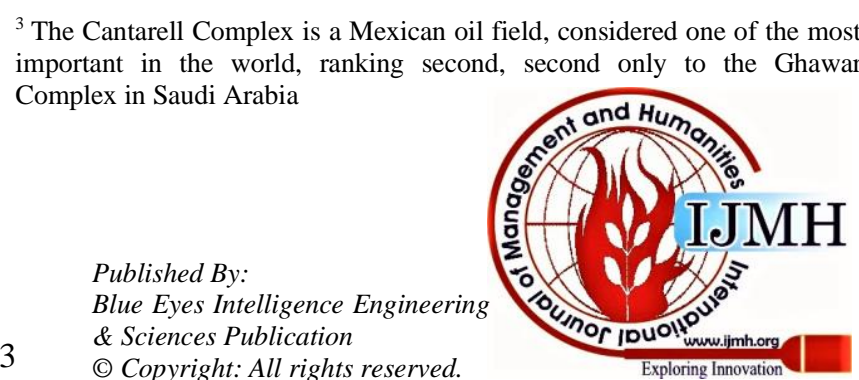


Moving on to the groups of commodities that Mexico imports the most, the third group corresponds to the agricultural group which represents $7 \%$ of the Mexican imports. It should be noted that according to the Food and Agriculture Organization of the United Nations (FAO), Mexico imports 43 percent of the food it consumes and is the second largest importer of food per capita after Japan. A nation should produce 75 percent of the food it consumes to avoid food dependency, FAO says. Nevertheless Mexico's dependence on imports to satisfy domestic demand for the main grains, oilseeds and fodder has grown in the recent 20 years. In 2014, 79 percent of the rice, 50 percent of the wheat and 22 percent of the corn consumed in Mexico came from abroad, reason why Mexico works to reduce this dependency and in 2019 there was a decrease of 90 thousand 557 tons in the purchases of soybeans, which represented a fall of $19.7 \%$, likewise, there was a decrease of $32.4 \%$ in wheat imports. ${ }^{4}$

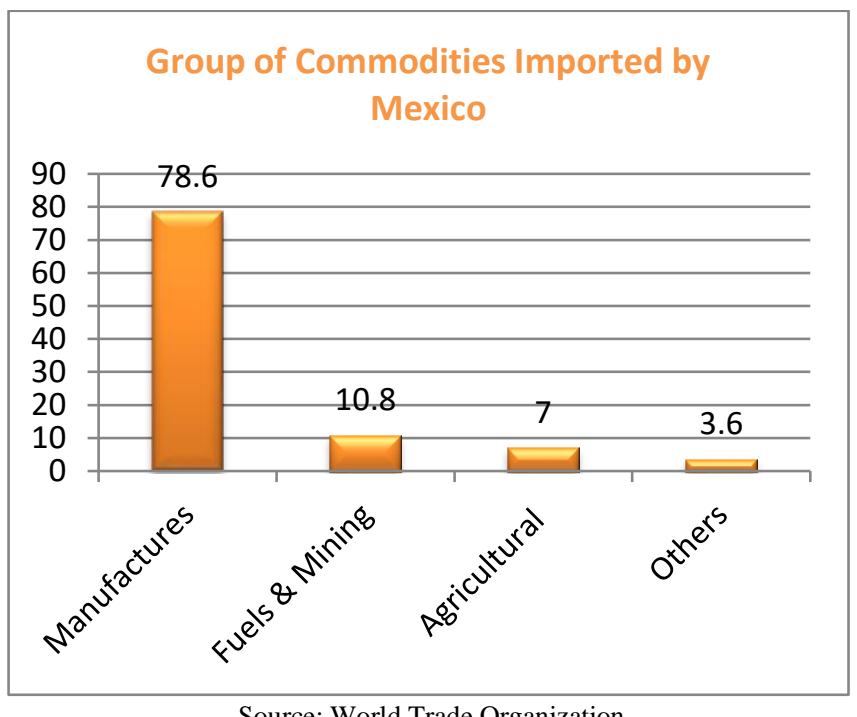

Source: World Trade Organization

In this order of ideas, in the following two tables, it can be appreciated more detail and exact numbers of the offers and demands that Mexico had in 2018 according to the World Trade Organization ${ }^{5}$. All these exports and imports are classified in Agricultural Products and Non-Agricultural Products. In the first group it can be appreciated that in 2018 Mexico exported 4, 491 million US\$ of beer; 2, 893 million US\$ of dates, figs, pineapples and avocados and 2, 261 US million dollars of tomatoes; while it imported 3, 289 million US\$ of maize ${ }^{6} ; 2$, 002 million US\$ of soy beans; 1,379 million US\$ of swine meat; 1, 169 million US\$ of wheat and 1, 062 million US\$ of meat and edible offal poultry.

\begin{tabular}{|c|c|c|c|}
\hline \multicolumn{4}{|c|}{ Agricultural Products } \\
\hline Top exported products (Million USȘ) & $\begin{array}{l}\text { Value } \\
2018\end{array}$ & Top imported products (Million USȘ) & $\begin{array}{l}\text { Value } \\
2018\end{array}$ \\
\hline H52203 Beer made from malt & 4491 & H511005 Maire (corn) & 3289 \\
\hline HSO804 Dates, figs, pineapples, avocados & 2893 & HS1201 Soya beans, whether or not broken & 2002 \\
\hline H50702 Tomatoes, fresh or chilled & 2261 & H50203 Swine meat, fresh, chilled, frozen & 1379 \\
\hline H50709 Other vegetables, fresh or chilled & 2218 & HS1001 Wheat and meslin & 1169 \\
\hline H52208 Alcohol of less than 80\% volume & 1723 & HS0207 Meat and edible offal of poultry & 1062 \\
\hline
\end{tabular}

Source: World Trade Organization

\footnotetext{
${ }^{4}$ Mexican Agro-food and fisheries information service https://www.gob.mx/siap/documentos

${ }^{5}$ Latest available information

${ }^{6}$ In 2018, Mexico became the main importer of maize, despite the fact that all those 59 varieties of maize are from it.
}

Published By:

Blue Eyes Intelligence Engineering

\section{Top exported products (Million USSS) \\ HS8703 Motor cars for transpoort of persons \\ HS8708 Parts for motor vehicles 8701.8075 \\ HS2709 Petroleum oils, crude}

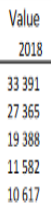

de in Commercial Services

Mexico focuses on trade in services to stimulate its economy and become more attractive. Mexico is a signatory of the General Agreement on Trade in Services and has entered into several bilateral trade agreements that contain provisions on trade in services. Moreover, Mexico has signed various multilateral and regional agreements that deal with trade in services, in addition to trade in goods. Its most important regional free trade agreement, NAFTA (today USMCA), sets outs the requirements for cross-border trade in services between the three member countries, United trade in services include the:

- $\quad$ Free trade agreement (FTA) between Mexico and the EU, signed on 8 December 1997.

- $\quad$ Pacific Alliance, signed by Chile, Colombia, Peru and Mexico on 6 June 2012.

- $\quad$ FTA in Central America with Costa Rica, Salvador, Guatemala, Honduras and Nicaragua.

Additionally, Mexico is currently participating in the negotiations of $\mathrm{TiSA}^{7}$ with 23 other countries, including the US, Canada and the EU. TiSA is aimed at liberalizing worldwide trade in services such as banking, healthcare and transportation.

Even though Mexico has worked to build this entire trade service network, in 2018 its share in world total exports,

${ }^{7}$ The Trade in Services Agreement (TiSA) is a trade agreement currently being negotiated by 23 members of the World Trade Organization (WTO), including the EU. Together, the participating countries account for $70 \%$ of world trade in services. TiSA is based on the WTO's General Agreement on Trade in Services (GATS), which involves all WTO members. The key provisions of the GATS - scope, definitions, market access, national treatment and exemptions - are also found in TiSA. The talks are based on proposals made by the participants. TiSA aims at opening up markets and improving rules in areas such as licensing, financial services, telecoms, ecommerce, maritime transport, and professionals moving abroad temporarily to provide services.

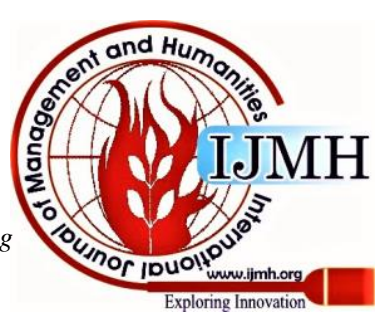




\section{Development of Trade Relations Between Mexico and China Under Non-Bilateral Trade Treaties}

when it comes to commercial services, was only $0.49 \%$ and its share in world total service import was $0.68 \%$; having a total of commercial service exports of 28, 381 million US\$ and 37, 049 million US\% of commercial service imports. The exports of services were mainly in travel and transport sectors. In this regard The United Nations Educational, Scientific and Cultural Organization (UNESCO) has awarded 204 cities the title of Cultural Heritage of Humanity, in Mexico, 10 cities have received this distinction in the category of cultural assets, due to their historical, architectural and urban value.

According to the World Travel and Tourism Council (WTTC) the travel and tourism sector in Mexico grew 2.4\% in 2018, an amount slightly higher than the behavior of the Mexican Gross Domestic Product (GDP) that was 2\%, with which the industry contributed $17.2 \%$ of the national GDP.

The importance of the tourism sector in the Mexican economy is that while this industry contributed $10.4 \%$ of GDP in 2018, in Mexico it was 17.2\%. WTTC, which represents 170 of the CEOs of the private sector in 185 countries, from companies such as airlines, hotels, amusement parks and others, reported that at the end of 2018, Mexico remained the tenth largest travel and tourism economy in the world.

\section{Mexican Exports by Service Sectors}

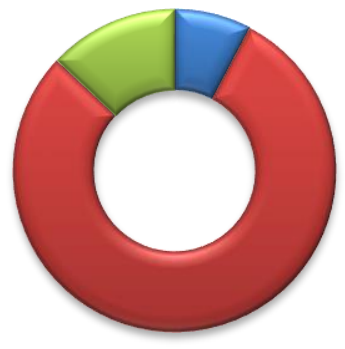

QTransport

$\square$ Travel

$\square$ Others

Source: World Trade Organization

\section{Mexican Imports by Service Sectors}

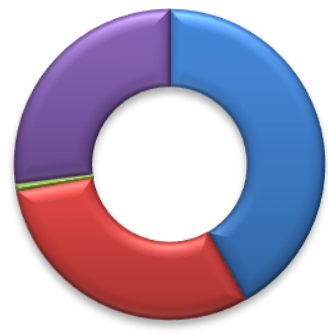

$\square$ Transport

$\square$ Travel

$\square$ Goods-related services

\section{Source: World Trade Organization}

In this point, $79.3 \%$ of the total exported services by Mexico were in the travel sector, $7.7 \%$ in the transport sector and the remaining $13 \%$ covers diverse sectors; while regarding the imports in services were mainly in the transport sector followed by the travel sector, by $41.8 \%$ and $30.5 \%$, respectively. The internal demand in the travel sector has been representative, $85 \%$ of the contribution to this sector came from the pockets of national travelers, and 15\% from international ones. According to WTTC, from that $15 \%$ of international visitors $80 \%$ came from United States, being visitors from this country the most representative for the travel industry; followed by 5\% from Canada, 2\% from UK and Spain, 1\% from France and 11\% from the rest of the world. It is in this last percentage where Chinese visitors are included which represent less than $1 \%$ of the truism that Mexico receives, which means that this is an area of opportunity that Mexico should not miss; even more when the statistics have shown that during 2018, tourists spent 23.007 million dollars in Mexico, equivalent to $4.9 \%$ of total exports; which mean that if the travel sector is promoted among Chinese market, the imports could growth and with it, the Mexican economy too.

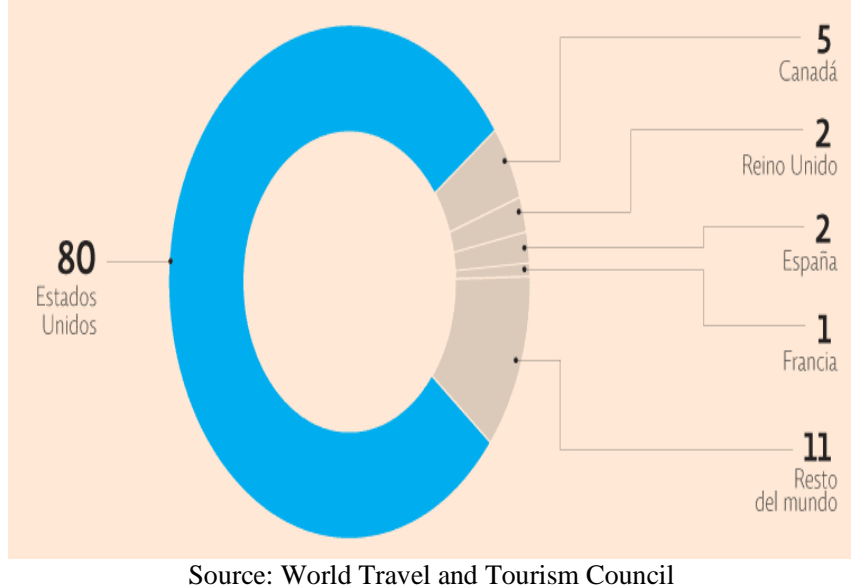

At the same time, in the travel sector, in 2018 the exports were 22, 506 million US\$ and the imports were 11, 288 million US\$; while the exports of other commercial services and goods-related services 3, 683 million US\$ and the imports under the same category were 9, 987 million US\$, from which the $84.4 \%$ was occupied by insurance and pension services, the $12.1 \%$ by financial services, the $1.7 \%$ by Information and communications technology (ICT's) and the reaming $1.8 \%$ was covered by other types of services.

\section{Exports of OCS by main item (2018)}

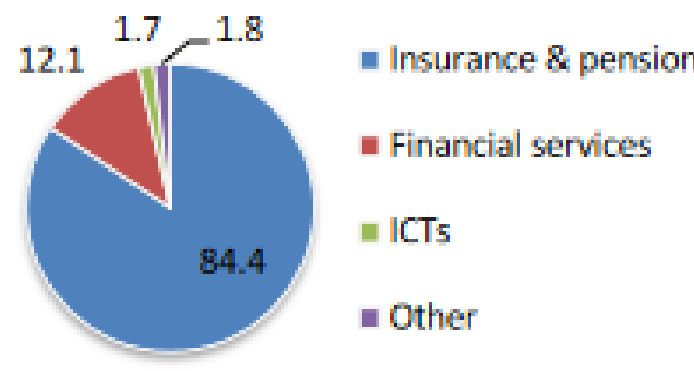

Source: World Trade Organization

The total exports of transport in 2018 were for 2, 183 million US\$; while the imports were for 15, 482 million US\$. The transport exports by sea represented 3\% with 66 million UD\$, the exports by air represented $78.4 \%$ with 1 , 711 million US\$ and $18.6 \%$ was occupied by other types of transport with 405 million US\$. At the same time, the transport imports by sea represented 59.9\% with 9, 275 million US\$; the imports by air represented 39.9\% with and other types of transportation occupied only $0.2 \%$ with 27 million US\$.

Published By:

Blue Eyes Intelligence Engineering \& Sciences Publication

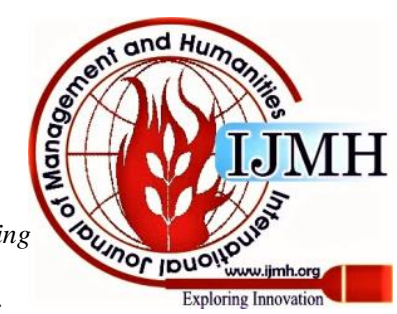




\section{Transport Exports}

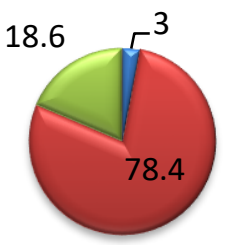

$\square$ By sea $\quad \square$ By air $\square$ Others

\section{Transport Imports}

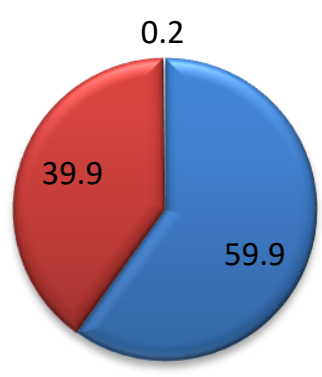

$\square$ By sea $\quad \square$ By air $\square$ Others

Source: World Trade Organization

Out of those statistics, it should be highlighted that regarding trade of services, Mexico has done a representative work in the travel sector, but still has to consider, study and analyzed new areas of opportunity.

\section{F. Mexico Trade Balance}

Timely foreign trade information from February 2020 indicates a trade surplus of \$2,911 million, a balance that compares with the surplus of $\$ 1.34$ billion obtained in the same month of 2019. In the first two months of this year, the balance Commercial presented a surplus of 495 million dollars.

Exports.- Last February, the value of merchandise exports reached \$36,634 million, a figure that was made up of $\$ 34,876$ million of non-oil exports and $\$ 1,758$ million of oil exports. Thus, in the referred month, total exports showed an annual growth of $0.6 \%$, which was the net result of a $3.1 \%$ rise in non-oil exports and a variation of (-) 32\% in oil exports. Within non-oil exports, exports to the United States advanced at an annual rate of $4.4 \%$, while those channeled to the rest of the world decreased (-) 2.4 percent. With this result it is evident that Mexican purpose to diversify its trade to the rest of the world is still far away to be reached, and in the contrary, its exports are still highly concentrated in the US market.

With seasonally adjusted figures, in February 2020 total merchandise exports reported a monthly variation of (-) $3.32 \%$, which was the result of declines of (-) $1.64 \%$ in nonoil exports and (-) 28.34\% at the oil companies.

Imports.- The value of merchandise imports in February this year was 33,724 million dollars, an amount that implied an annual fall of (-) 3.9\%. This figure was a reflection of decreases of (-) 3.3\% in non-oil imports and (-) 8.7\% in oil imports. When considering imports by type of good, annual decreases of (-) $3.7 \%$ were observed in imports of intermediate-use goods and (-) $11.1 \%$ in those of capital goods, while there was an increase of $0.4 \%$ in imports of consumer goods.

With seasonally adjusted series, total imports showed a monthly drop of (-) $1.92 \%$ with seasonally adjusted data, which was derived from reductions of (-) $0.88 \%$ in non-oil imports and (-) $10.67 \%$ in oil imports. . By type of good, there were monthly decreases of (-) $6.19 \%$ in imports of consumer goods, (-) $1.11 \%$ in those of intermediate-use goods and (-) 2.16\% in those of capital goods.

\section{Mexican Trade Balance}

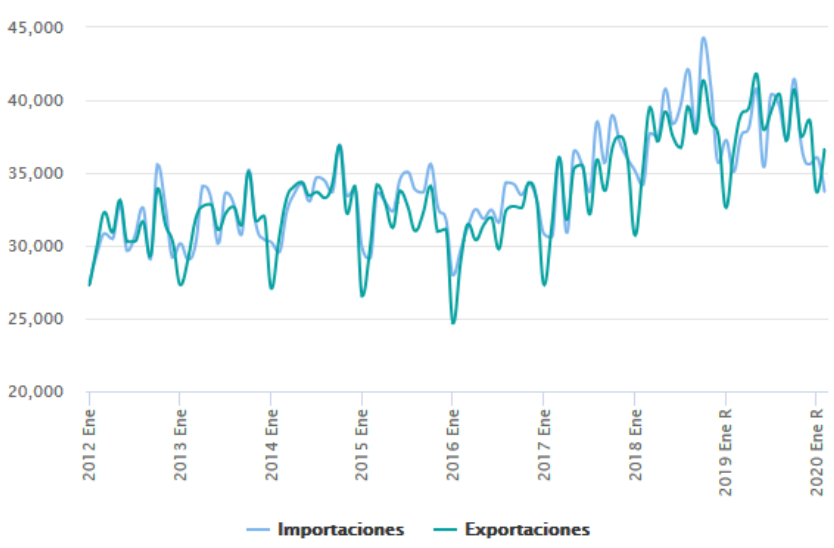

Source: Mexican National Institute of Statistics and Geography ${ }^{8}$

\section{G. Status of the China's Trade: Imports and Exports}

During the first two decades of the century, the unfolding of China in its integration with the world stands out in an important way. In September 2001, China formally adhered to the World Trade Organization (WTO), after a long period of negotiation that began in 1986, in an act that at that time protocolized its role as third world economy and sixth exporting nation, as an obvious act that left no doubt about its success over the last decades.

According to the 2019 World Investment Report published by UNCTAD, China was ranked the world's second largest FDI recipient after United States and before Hong Kong. The country is the largest recipient in Asia. China's economy was ranked the second most attractive to multinational companies for 2017-2019, only behind the U.S. With steady growth for several years, FDI inflows continued to increase between 2017 and 2018, from USD 136 billion to 139 billion ( $+3.7 \%$, all-time high).

This growth is favored by liberalization plans, the rapid development of the high-tech sector and the establishment of free trade zones. Despite trade tensions with the United States, more than 60000 companies were established by foreign investors in 2018, a 70\% increase compare to 2017. The country continued absorbing flows from developing Asian countries and developed countries such as UK and Germany. However, inflows from the US decreased from

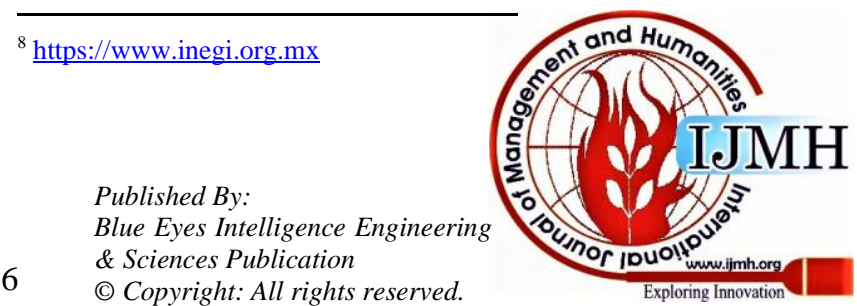




\section{Development of Trade Relations Between Mexico and China Under Non-Bilateral Trade Treaties}

$\$ 10$ to $\$ 6$ billion in 2018. Stocks increased by 9\%, reaching 1627 billion (12.1\% of the GDP).

Additionally, China was ranked 31st out of 190 countries in the World Bank's 2020 Doing Business report, a major improvement from 2019, when it was ranked 46th out of 190. China was one of the top 10 economies to improve the most between the 2019 and the 2020 reports. This progress reflects improvement in a wide array of subcomponents ranging from procedures to start business there to measures to improve electricity access and get construction permits. All this factors have contributed and are the context under which China is located today in the international scale, which is analyzed right away.

\section{H. China Trade Market Share}

According to the World Trade Organization, today there is no doubt that China is the largest merchandise exporter and the second merchandise importer, just after United States, holding $12.8 \%$ and $10.8 \%$ of the world market share, respectively; having an annual percentage change of 10 in its exports and 16 in its imports. While if the European Union is considered as a one economic entity, China remains its place as exporter leader of merchandise, but falls one point as merchandise importer, being followed by Japan and Hong Kong.

Leading exporters and importers in world merchandise trade, 2018

(Billon dollars and percentage)

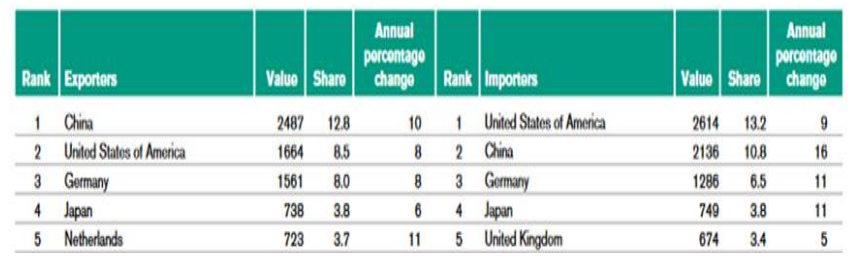

Leading exporters and importers in world merchandise trade (excluding intra-EU (28) trade), 2018 (Billion dollars and percentage)

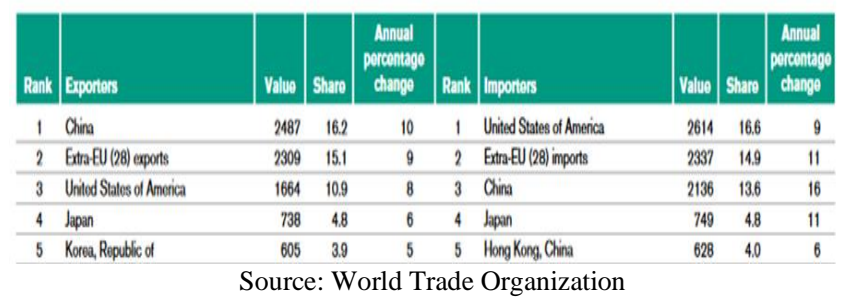

Regarding commercial services, in $2018^{9}$ China ranked as the number $5^{\text {th }}$ as exporter and number $2^{\text {nd }}$ as importer, but again if the European Union is consider as a one economic entity China's positions shift to be the $3^{\text {rd }}$ largest exporter and importer of commercial services. As consequence of this trends and numbers, today China is the second largest global economy, has the largest exchange reserves in the world and has one of the fastest growing GDPs in the world, nevertheless in 2019 economic growth slowed slightly, reaching $6.1 \%$. That trend is likely to continue in 2020 and 2021, when the GDP is expected to grow 5.8\% and 5.9\%. That is the result of a structural slowdown, as the economy moves away from an investment-led growth model and the government implements policies to reduce financial vulnerabilities. Resilient external demand and robust

\footnotetext{
${ }^{9}$ Latest available data
}

domestic household consumption bolstered this growth, despite rising concerns about financial risks amid an economic restructuring led by the Communist government. New sectors like e-commerce and online financial services are gaining momentum in an economy dominated by exportoriented sectors.

\section{China Main Trade Partners}

Along history, China has had different trade partners; during the 1950s China's primary foreign trading partner was the Soviet Union. In 1959 trade with the Soviet Union accounted for nearly 48 percent of China's total. As relations between the two countries deteriorated in the early 1960s, the volume of trade fell, decreasing to only just over 7 percent of Chinese trade by 1966. During the 1970s trade with the Soviet Union averaged about 2 percent of China's total, while trade with all communist countries made up about 15 percent.

Later, by the mid-1960s Japan had become China's leading trading partner, accounting for $15 \%$ of trade in 1966. Japan was China's most natural trading partner; it was closer to China than any other industrial country and had the best transportation links to it. In the early 1960s, Hong Kong was consistently the leading market for China's exports and its second largest partner in overall trade. In 1986 Hong Kong received 31.6 percent of Chinese goods sold abroad and supplied about 13 percent of China's imports.

By 1979, the United States became the second largest importer to China and in 1986 was China's third largest partner in overall trade. Most American goods imported by China were either high-technology industrial products, such as aircraft, or agricultural products, primarily grain and cotton. In 1986 Western Europe accounted for nearly 18 percent of China's foreign trade, with imports exceeding exports. In 1986 developing countries purchased about 15 percent of Chinese exports and supplied about 8 percent of China's imports. China has increased trade and investment ties with many African countries such as Chad, the Sudan, and the Democratic Republic of Congo, partly to secure strategic natural resources such as oil and minerals.

China has signed various Free Trade Agreements (FTA's) with several nations, including: Peru, Costa Rica, Chile, Mauritius, Maldives, Georgia, Australia, South Korea, Switzerland, Iceland, Singapore, New Zealand, Pakistan, Hong Kong and Macao 10. Nevertheless the main trade partners are not precisely the countries with which it has signed those FTA's, what is an indicator to proof that those agreements are a tool but not the end to carry out trade commerce.

According to the latest data issued by the World Trade Organization, today China's main trade partners are United States with 19.2\%, Hong Kong with 12.1\%, Japan with $5.9 \%$, South Korea with $4.3 \%$ and Vietnam with $3.3 \%$ as receptors of China's exports; where the remaining $55.2 \%$

${ }^{10}$ China Free Trade Agreement Network
http://fta.mofcom.gov.cn/index.shtml
Published By:
Blue Eyes Intelligence Engineering
\& Sciences Publication
(C) Copyright: All rights reserved.


goes to the rest of the world in percentage below 3.3\%, including Europe, Latin America and Africa.

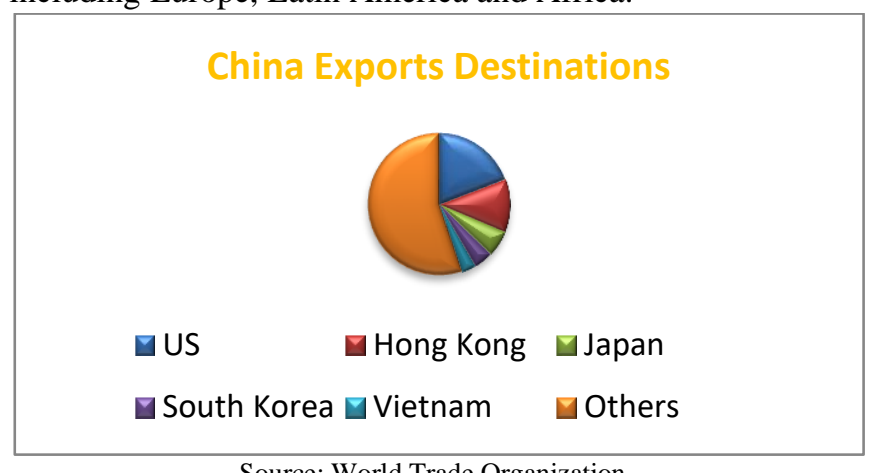

Source: World Trade Organization

Regarding the main suppliers of China, the list is headed by South Korea, followed by Japan and the United States; in the first case representing $9.5 \%, 8.4 \%$ and $7.3 \%$ of the Chinese purchases, respectively. In the fourth place it's Hong Kong-Taiwan with a market share of $6.8 \%$ and in the fifth largest supplier is Germany holding $5 \%$ of Chinese imports.

\section{Chinese Main Suppliers}

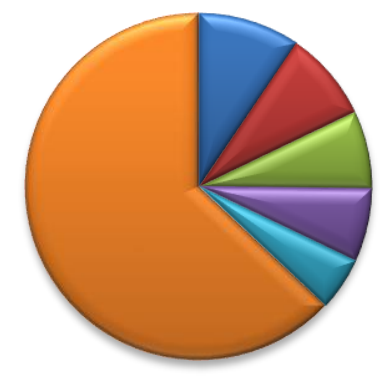

\section{$\square$ South Korea $\square$ Japan $\square$ US \\ $\square$ HK-Taiwan $\square$ Germany $\square$ Others}

Source: World Trade Organization

As China is the main competitor of the United States, in recent years the tensions between these two trade partners have increased and their economic relationship have heightened business uncertainties; given that the US is the country's main trade partner (China's 2017 trade surplus with the U.S. was USD 275.81 billion, an all-time record). However, the Chinese government has been adopting looser economic policies to mitigate mounting risks to future growth.

Although countries from Latin America and Africa are not in the list of the main suppliers of China, China purchases raw materials from countries of those two continents. These include oil and other fuels, metal ores, plastics, and organic chemicals. It's the world's largest importer of aluminum and copper.

This position of China as the largest exporter of merchandise and the second largest importer of the world makes it clear that its international trade is embedded in the DNA of the Chinese economy, and that is one of the main reasons why countries exports target China, besides of its huge population and workforce, its economic leadership, the raising of its middle class and its increase in consumption.

\section{J. China Commodities Trade}

Trade has become an increasingly important part of China's overall economy, and it has been a significant tool used for economic modernization. As reported by WTO, exports of goods in 2018 were USD 2,494.2 billion and imports USD 2,134.9 billion, while exports and imports of services in 2018 reached USD 266.8 billion and USD 525.0 billion respectively. China reported an overall $19.5 \%$ increase in exports and $18.7 \%$ rise in imports in 2018. According to the World Bank data of 2018, China's trade surplus for goods stood at USD 359.2 billion, a decline from USD 475.9 billion in 2016.

The merchandise that China sells to the world are classified mainly in three different groups, which are manufacture sector as the largest representing 93.9\% of the Chinese exports of goods, then followed by the agricultural sector occupying $3.4 \%$ and finally the fuel and mining products which represents $2.7 \%$ of the total of Chinese sells.

\section{Chinese Exports by Groups}

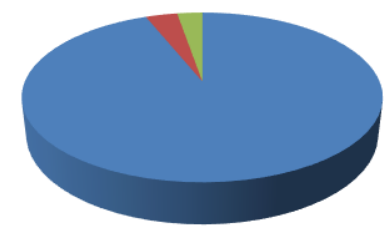

Manufactures Agricultural Fuels \& Mining

Source: World Trade Organization

Within the first and most important Chinese sector, the manufactures, the distribution is quite large if it is considered that China is the largest supplier of the world; however the classification can be as follow:

- Transmission apparatus for radio-telephony, radiotelegraphy, radio broadcasting or television, whether or not incorporating reception apparatus; television, cameras represent $7.9 \%$;

- Automatic data processing machines and units thereof, magnetic or optical readers, machines for transcribing data onto data media in coded form represent $7 \%$;

- $\quad$ Electronic integrated circuits and micro assemblies represent 3.4\%;

- Electrical apparatus for line telephony or line telegraphy, line telephone sets with cordless handsets and telecommunication apparatus for carrier-current line systems occupy $2.2 \%$;

- Parts and accessories (other than covers, carrying cases and the like) suitable for use solely or principally with machines, represent $1.8 \%$.

- Furniture including bedding, lighting, prefab buildings and signs represent $4.2 \%$;

Published By:

Blue Eyes Intelligence Engineering \& Sciences Publication

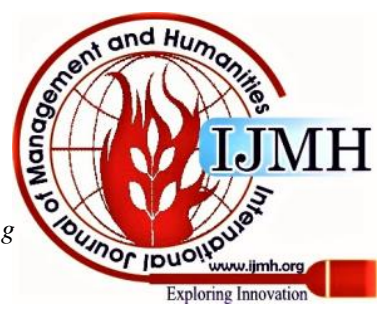




\section{Development of Trade Relations Between Mexico and China Under Non-Bilateral Trade Treaties}

- Knit or crochet clothing, including accessories represent 3.5\%;

- $\quad$ Clothing, accessories represent 3.4\%;

- Optical, technical, and medical apparatus represent $3.2 \%$;

- $\quad$ Plastics and associated items represent 3\%;

- Vehicles represent 2.9\%;

- $\quad$ Iron and steel products represent 2.5\%;

- $\quad$ Footwear represent $2.3 \%$

In the second group of Chinese exports, the agricultural sector, among the exported products exported there are dried vegetables, onion, shallots, garlic, leeks, apples, pears and quinces. Additionally, China is the largest cotton spinner in the world and the textile industry is also the biggest globally in terms of overall production and exports. Twenty four of the provinces in China grow cotton and the industry is responsible for employing about 300 million people in the country. Also there is tea, the Asia Pacific region is the largest tea producer and China plays a pivotal role in global tea production. Bad weather and cold temperatures can have a notable impact on tea production and has affected growth rates in certain years. One more representative product in the list is rice, which annual production accounts for almost half of the country's total grain output. China is responsible for about $30 \%$ of global rice production. Rice yields in China have risen significantly since the introduction of scientifically-bred high-yield dwarf rice that has proven resilient in cold and adverse weather conditions.

On the other hand, in the fuel and mining group, according with the Chinese Business Data Center, in February of this year, fossil fuels, lubricants and related raw material were the products with the highest rate of exportations, followed by petroleum, petroleum products and related raw material, to finally have in the third place still with exports for 6229583 thousand US\$, as it can be appreciate in the following table:

\begin{tabular}{lc}
\hline \multicolumn{1}{c}{ Commodity } & $\begin{array}{c}\text { Exported amount in } \\
\text { Thousand US\$ during } \\
\text { Feb. } 2020\end{array}$ \\
\hline $\begin{array}{l}\text { Metal ore and metal } \\
\text { scrap }\end{array}$ & 287783 \\
\hline $\begin{array}{l}\text { Fossil fuels, lubricants } \\
\text { and related raw materials }\end{array}$ & 7061823 \\
\hline $\begin{array}{l}\text { Coal, coke and briquettes } \\
\text { Petroleum, petroleum } \\
\text { products and related raw } \\
\text { materials }\end{array}$ & 169716 \\
\hline Natural gas and artificial & 6487948 \\
\hline
\end{tabular}

gas

Productos minerales no

metálicos.

\begin{tabular}{ll} 
Steel & $\mathbf{6 2 2 9 5 8 3}$ \\
\hline Non-ferrous metals & 3335880
\end{tabular}

Source: Minister of Commerce of People's Republic of China

As the second largest importer of the world, according to the World Trade Organization, in 2018 China held the $10.8 \%$ of the global imports market share. The diversification of its imports were mainly concentrated in three different groups, as its exports but in different percentage; it is manufactures in the first place occupying $62.5 \%$; then fuels and mining products representing 24.1\%; followed by imports of agriculture products representing $9.8 \%$ of the total Chinese imports.

\section{Chinese Imports by Groups}

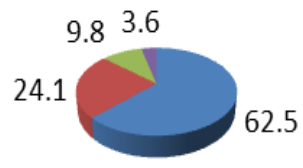

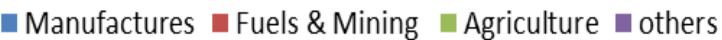

Source: World Trade Organization

China's top 10 imports account for over three-quarters (77.3\%) of the overall value of its product purchases from other countries, among the products imported to the manufacture group there are electrical machinery, equipment (24\% of total imports); electronic integrated circuits and micro assemblies (14.7\% of total imports); optical, technical, medical apparatus (4.8\% of total imports); plastics, plastic articles (3.5\% of total imports); motor cars and other motor vehicles principally designed for the transport of persons, stations wagons and racing cars $(2.3 \%$ of total imports).

Adding to the fuel and mining category, the products imported are petroleum oils and oils obtained from bituminous minerals, crude (11.2\% of total imports); iron ores and concentrates, roasted iron pyrites (3.5\% of total imports); gems, precious metals (2.9\% of total imports); petroleum gas and other gaseous hydrocarbons $(2.3 \%$ of total imports); copper ( $2 \%$ of total imports).

Lastly, in the agricultural group the imported products are soy beans, malt extract, palm oil and its extracts, meat of bovine animals and wine. The country's agricultural sector has become increasingly more dependent on imports over the last decade, in particular, oil bearing crops such as soybeans.
Published By:

Blue Eyes Intelligence Engineering

\& Sciences Publication

(C) Copyright: All rights reserved.

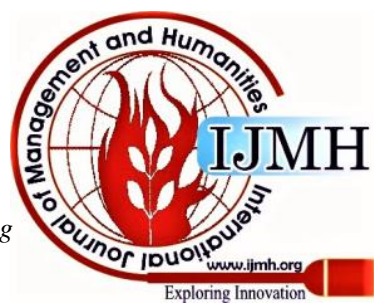




\section{K. Chinese Trade in Commercial Services}

According to the Minister of Commerce of People's Republic of China, China's import and export of services have maintained a rapid growth. In its report of 2018, the total volume of China's imports and exports of services reached 3445.77 billion yuan, up $10.5 \%$ year on year. Among these, the exports totaled 1132.28 billion yuan, up 14.4\%; the imports reached 2313.49 billion yuan, up $8.7 \%$; the trade deficit was 1181.21 billion yuan. In terms of the US dollar, the growth rates of the total imports and exports of services, exports of services, and imports of services were $16.4 \%, 20.5 \%$ and $14.5 \%$ respectively.

For years, Chinese government has been putting effort into shifting its economy toward a growth model driven by consumption, services and innovation, thus contributing to global economic growth. Even though China keeps growing in this sector, today it accounts $4.59 \%$ of the global market share in commercial services; exporting services from different categories such as transport and travel, 16\% and $14.9 \%$ respectively; while it imports from transport sector $20.8 \%$ and from travel sector $53.2 \%$.
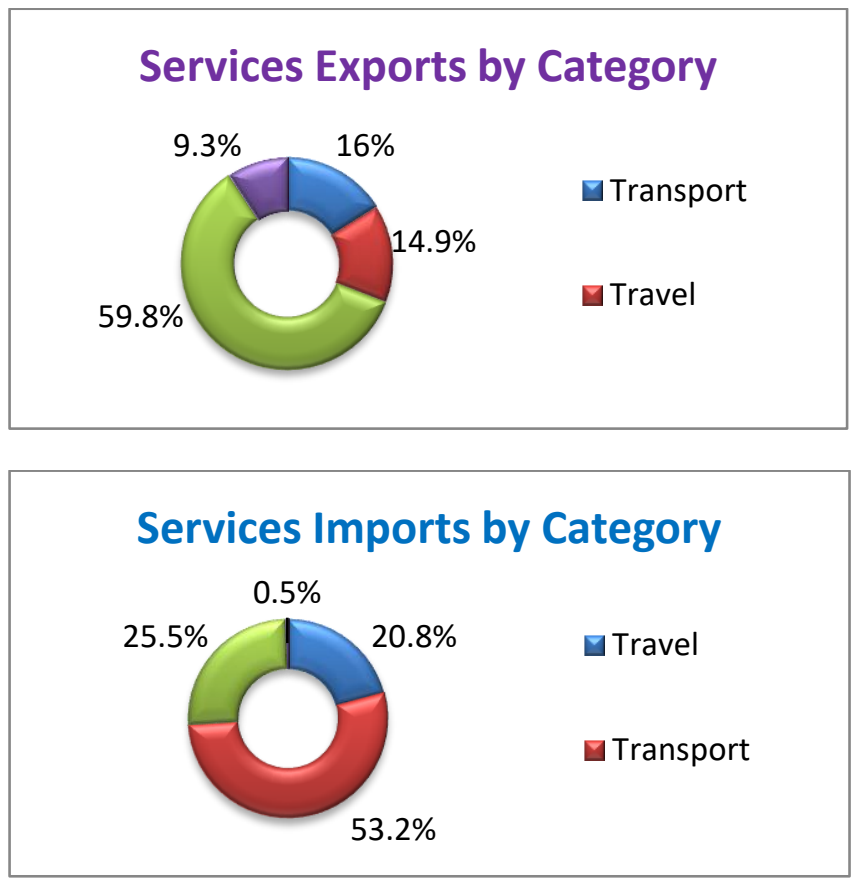

Source: World Trade Organization

Among those other sectors, China has taken steps to improve the development of trade in services, including gradually opening up the finance, education, culture and medical treatment sectors. It is considered by Chinese government that with further improvement in transportation, logistics and communication and e-commerce development in rural areas residents have been unleashing their consumption potential for both goods and services. As a consequence, the competitiveness of China's services trade has been strengthened, and the country is gradually shifting from a power of trade in goods to a services trade power, that is so because the optimized structure of the service industry is influenced by China's economic transformation and upgrading.
Likewise, using Foreign Direct Investment as a tool not only to have capital flows, but it also has been use to learn from the technology in all aspects, including commercial services, therefore the main trade partners of Chinese commercial services destinations are Hong Kong receiving 28.8\%; the European Union accounting $17 \%$ of the Chinese commercial services; followed by United States with $15 \%$; the Japan and Singapore with a representative decrease, receiving only 5.5\% of the Chinese services each of them; while commercial services imports come mainly from Hong Kong 19.6\% of them, which are almost the same as the ones coming from the United States, 19.3\%; followed by the commercial services supplied by the European Union representing $16.9 \%$; the Japan representing $6.6 \%$ of the imports and Canada, accounting 5.8\%.

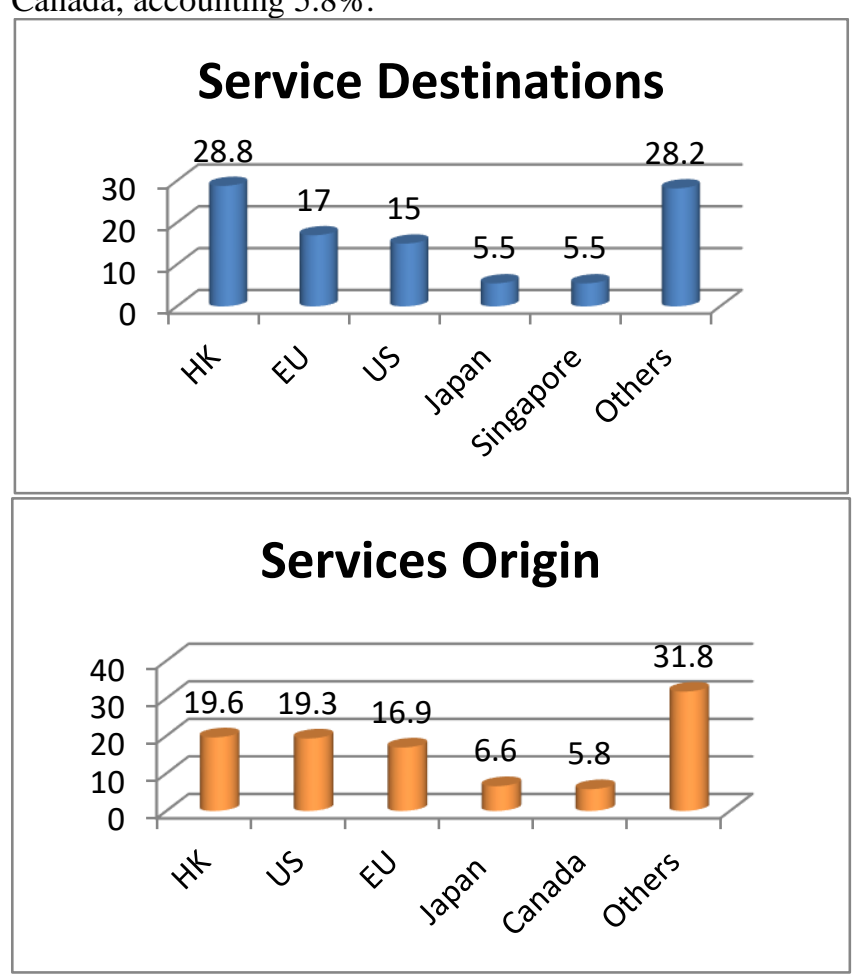

Source: World Trade Organization

As it has been mentioned, the commercial service sector in China keeps moving on forward, however, as it can be observe in the charts above, still there is deficit in the Chinese trade balance. In this sense the growth of services' export was higher than that of import. In 2018, according to Chinese Minister of Commerce, services' export continued its rapid growth since this year, and the growth rate of export was 5.7 percentage points higher than that of import. Among these, the top three sections in terms of growth rate were telecommunication, computer and information services, personal culture and entertainment services and insurance services, with their growth rates being $61.1 \%$, 38.8\% and $26.5 \%$ respectively. That is why the forecast of Chinese government is that services trade will continue its strong run in the near future as the country deploys more resources to stimulating domestic consumption, infrastructure development and high-value-added manufacturing, as well as the Chinese people's surging demand for overseas trips, education and healthcare services.

Published By:

Blue Eyes Intelligence Engineering \& Sciences Publication

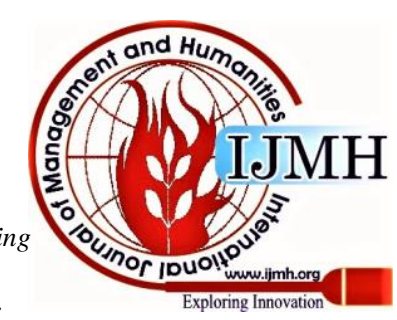




\section{Development of Trade Relations Between Mexico and China Under Non-Bilateral Trade Treaties}

Still yet, the he proportion of import emerging services has increased gradually. In 2018, imports of emerging services had a rapid growth, taking up $23.6 \%$ of service import, 1.6 percentage points higher than that of the same period last year. Among these, the growth rates of import of financial services, intellectual property royalties, and telecommunication, computer and information services were all over $20 \%$, being $47.1 \%$, 23.3\% and 23.2\% respectively.

Additionally, other sectors that have been pushed by China's rapidly growing services sector include computing, industrial solutions and retail businesses, and increasing exports of emerging services such as telecommunications and insurance. In this order of ideas, according to the Chinese Minister of Commerce, in 2018 the total amount of import and export of emerging services reached 1138.39 billion yuan, up 20.9\%, 10.4 percentage points higher than the overall growth rate of import and export of services, pulling up the proportion of emerging services by almost 3\%. Among these, the export of emerging services was 593.23 billion yuan, up $25.5 \%$, the import 545.16 billion yuan, up $16.3 \%$.

\section{China Trade Balance}

As the logic suggests, it is not hard to understand that being China the largest exporter of the world it has had a surplus every year. As it can be seen in the table below in 2015 the surplus was 509.6 billion US\$; in 2016 it was 594.4 billion US\$; in 2017 it was 382.4 billion US\$, in 2018 it was 259.7 billion US\$ and finally in 2019, the latest year with available data, the surplus was 231 billion UD\$.

\begin{tabular}{|c|c|c|c|c|c|c|}
\hline \multirow{2}{*}{ Year } & \multicolumn{3}{|c|}{ Total trade } & \multicolumn{2}{c|}{ Exports } & \multicolumn{2}{c|}{ Imports } \\
\cline { 2 - 8 } & Amount & YoY & Amount & Yo & Amount & YoY \\
\hline 2019 年 & 45753.00 & -1 & 24984.10 & 0.5 & 20768.90 & -2.8 \\
\hline 2018 年 & 46230.40 & 12.6 & 24874.00 & 9.9 & 21356.40 & 15.8 \\
\hline 2017 年 & 41044.70 & 11.4 & 22634.90 & 7.9 & 18409.80 & 15.9 \\
\hline 2016 年 & 368499.30 & -6.8 & 20974.40 & -7.7 & 15874.80 & -5.5 \\
\hline 2015 年 & 395866.40 & -8 & 22765.70 & -2.8 & 16820.70 & -14.1 \\
\hline 2014 年 & 43030.40 & 3.4 & 23427.50 & 6.1 & 19602.90 & 0.4 \\
\hline 2013 年 & 416003.30 & 7.6 & 22100.40 & 7.9 & 19502.90 & 7.3 \\
\hline 2012 年 & 38667.60 & 6.2 & 204899.30 & 7.9 & 18178.30 & 4.3 \\
\hline \multicolumn{2}{|c|}{ Source: Chinese Minister of Commerce (in 100 million US\$) } \\
\hline
\end{tabular}

Additionally, in 2019 the trade decreased 1\% in comparison with the previous year, while in 2018 it reflected an increase $12.6 \%$ in comparison with 2017. Nevertheless in 2016 and 2015 there was a decrease of $-6.8 \%$ and $-8 \%$, respectively. Overall, 2019 was a year in which the trade has slowed down, actually Now, the world's second-largest economy is expanding at its slowest pace since the early 1990s. Domestic issues, the US-led trade war, and swine fever are all putting a brake on China's rapid expansion.

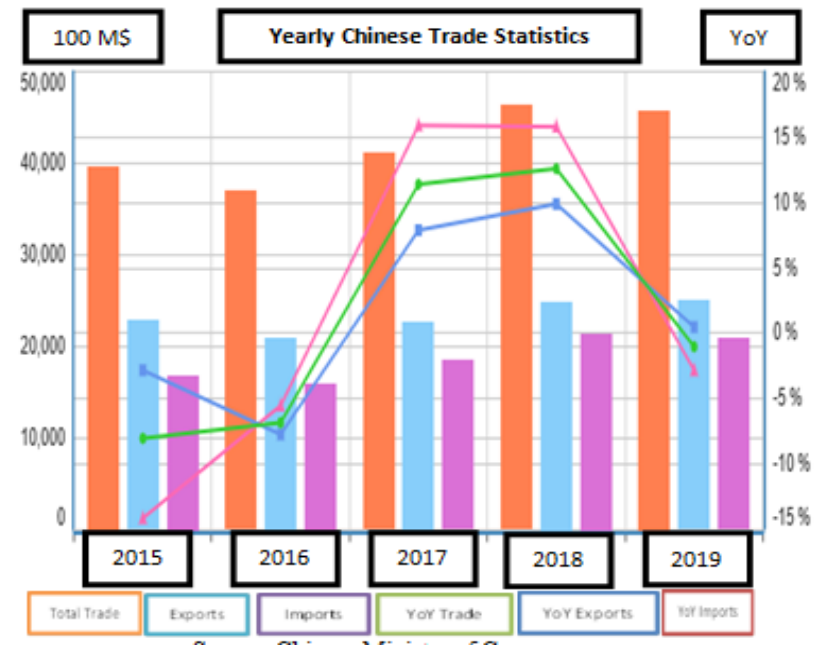

Source: Chinese Minister of Commerce

Nevertheless the trade war between United States and China has affected more the American economy than the Chinese, that is so because Chinese exports fell in 2019 by 1\% from a year earlier, and by a sharp $16 \%$ to the US, a clear sign that the dispute with the US is hurting bilateral trade.

Scholars such as Tommy Wu, senior Asia economist at Oxford Economics, consider that the slowdown in China is becoming quite significant; it is true that both the weakening in the domestic economy and deteriorating external environment, including both a global slowdown, and the US-China trade tensions, have a role to play in China's slowdown. Given China's importance in the global economy, and its healthy demand for anything from commodities to machinery, any downturn is likely to have far-reaching consequences.

Gary Hufbauer, of the Peterson Institute for International Economics in America, estimates that a one percentage point drop in Chinese growth would probably take 0.2 percentage points off global growth. On the opposite Frederic Neumann, co-head of Asian economics research at HSBC, considers that it's not as if Chinese growth has completely fallen off a cliff, but on the contrary, there are still many pockets of growth, for example, housing construction and spending in the services sector.

China's government has sought to support the economy through tax cuts, and by taking measures to boost liquidity in the financial system. That is because the government believes China needs to curb the risk in its financial system, and cool the rapid credit growth of recent years. However, tax cuts tend to be less effective in boosting growth than infrastructure spending. The US and China have been fighting a trade war for more than a year, and more tariffs are expected. Western businesses, meanwhile, are finding it increasingly hard to navigate the uncertainty, and as a consequence some have been shifting production out of China. This situation has also affected Mexico through USMCA, Agreement through which America has immersed in the Mexican-Chinese trade relationship to avoid the signature of any possible Free Trade Agreement between these last two countries.

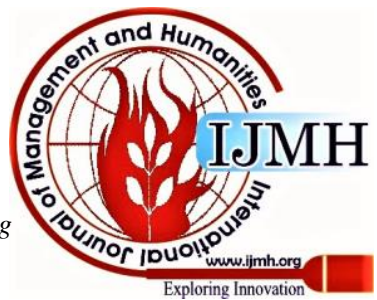


The longer these tariffs remain in place, the longer this drags on, the higher the chance for firms to shift out of China, and it also makes the country a less attractive place to invest in the first place. While many firms will want to keep some production in China to cater for its important domestic market, there are signs some firms are already considering their options. According to a 2019 survey by the American Chamber of Commerce in China, 65\% of members said trade tensions are influencing their longer-term business strategies. Nearly a fourth of all respondents are delaying China investments.

\section{III.CHINA AND MEXICO TRADE RELATIONSHIP}

This is an important subject considering the evolution of trade between the two countries. Since 1990, the bilateral trade balance has been deficient for Mexico, especially as a result of China entry into the World Trade Organization (WTO). It is not an exaggeration to point out that the geometric growth observed in the trade balance is the result of, mainly, Chinese actions, since, despite being an expanding market, the Mexican business community generally tends to ignore the opportunities offered by that country. ${ }^{11}$

\section{A. China and Mexico Market Share}

Already trade partners for over four decades, China and Mexico have a long history of economic cooperation and partnership. Economically speaking, China is today the second commercial partner of Mexico in the world and the third global destination of Mexican exports; while Mexico is the second largest trade partner of China in Latin America, just after Brazil.

\section{B. Signed agreements between China and Mexico}

In this regard, it is true that even though China is Mexico's second trading partner, today China and Mexico do not yet have a legal framework that creates a preferential trade relationship and allows us to be in a situation where trade and investment can occur without barriers, preferential tariffs and with greater fluency; however, it is important to emphasize that the intentions of collaboration and cooperation between the two countries, have not remained only in words or in mere protocol visits; these intentions are reflected in the work that has been done to consolidate bilateral agreements reached by both countries. Hence, China and Mexico have signed a total of 8712 bilateral agreements.

Under the Mexico-China Comprehensive Strategic Association, agreements have been generated and those have improved Mexico's access to the Chinese market. After

\footnotetext{
${ }^{11}$ Haro Navajas, Francisco. "China in North America: the relationship with Mexico and the United States". Nueva Sociedad No 203, 5-6/2006. Consulted online on January 28th, 2020. www.nuso.org/upload/articulos/3359_1.pdf.

${ }^{12}$ Source: Office of the Economic-Commercial Counselor of the Embassy of the People's Republic of China in the United Mexican States. Consultation made on its official website on January 22, 2020. http://mx.mofcom.gov.cn/article/zxhz/sbmy/201605/20160501323327.shtm l
}

only a health protocol with China was finalized between 2006 and 2013, in 2015, Mexico was the country with which the Chinese authorities have signed the most protocols and agreements to access to agriculture food products (dairy, corn, beef and tobacco). Today, progress is being made in the negotiation for access to other products such as bananas and blueberries.

\section{Trade between Mexico and China}

As it can be observed in the following table, according to the United Nations International Trade Statistics Database (UN COMTRADE ${ }^{13}$ ), that in the last twenty years the trade between Mexico and China has increased significantly, especially for China, in the case of Mexico, even though the trade has grown it still remind a big deficit, a situation that does not occur with States United of America because between those two partners actually exist a surplus that benefits Mexico. That is so due to USA is the main trade partner of Mexico.

Mexican trade in goods with China since 1990

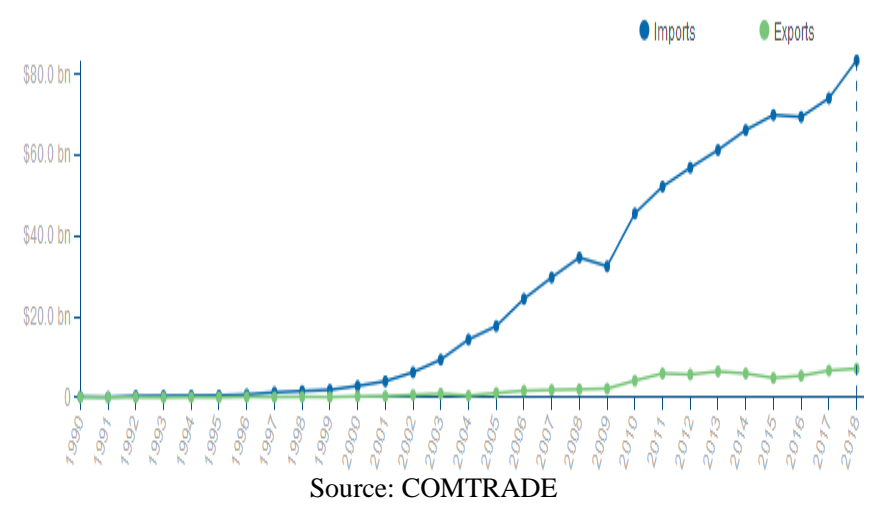

In 1999 China was the 32nd largest export market for Mexico (0.1\% of Mexico exports) and the 6th largest import market for Mexico (1.4\% of Mexico imports), in that year the commerce between Mexico and China was reported as following: exports \$ 126.3 million, imports for \$ 1.9 billion, with a deficit balance of - $\$ 1.8$ billion and a total bilateral trade of $\$ 2.0$ billion.

\section{Mexico Trade in Goods with China from 2000 to $2018^{14}$ in UDS bn.}

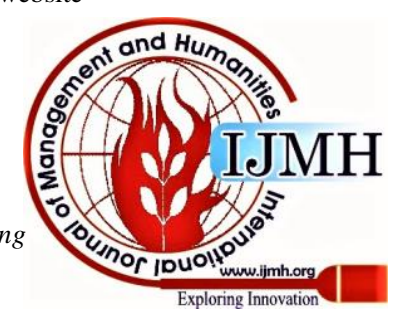




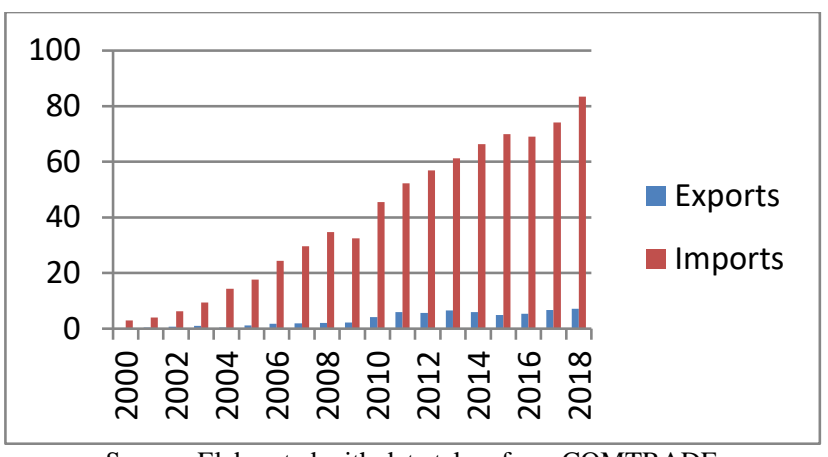

Source: Elaborated with data taken from COMTRADE

In 2000 Mexico's trade with China took a great leap in which China became the 19th largest export market for Mexico, rising more than 10 positions in this area, compared to the previous year, as just mentioned. In that year, trade between Mexico and China reported exports for \$ 310.2 million, imports for $\$ 2.9$ billion, with a deficit balance of $\$-2.6$ billion and a total bilateral trade of $\$ 3.2$ billion; later, in 2003 exports were reported for $\$ 974.3$ million dollars, imports for $\$ 9.4$ billion dollars, with a deficit balance of $\$$ 8.4 billion dollars and a total bilateral trade of $\$ 10.4$ billion, year in which China managed to position itself as the 6th largest export market for Mexico (0.6\% of Mexico exports) and the 2nd largest import markets for Mexico (5.5\% of Mexico imports).

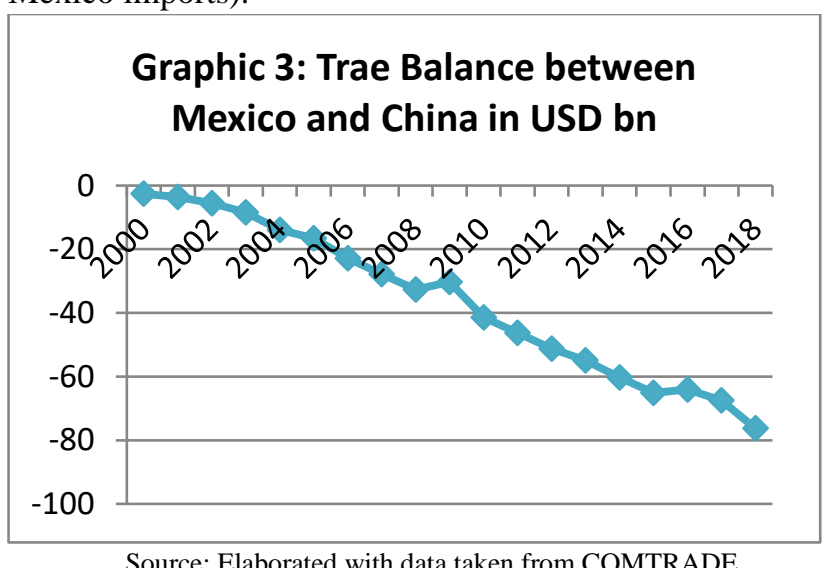

Three years later, in 2006, exports for $\$ 1.7$ billion dollars and imports for $\$ 24.4$ billion dollars were reported, with a deficit balance of $\$-22.8$ billion dollars and a total bilateral trade of $\$ 26.1$ billion losing a position as the market for exports, compared to trade in 2013, with China being the 7th largest export market for Mexico (0.7\% of Mexico exports) and the 2nd largest import market for Mexico (9.5\% of Mexico imports). In 2009, the seventh and second place positions for the export and import markets, respectively, were maintained with respect to 2013, reporting exports for \$ 2.2 billion and imports for $\$ 32.5$ billion, with a deficit balance of $\$-30.3$ billion of dollars and a total of bilateral trade of $\$ 34.7$ billion.

\section{Graphic 4: Bilateral Trade between Mexico and China in USD bn}

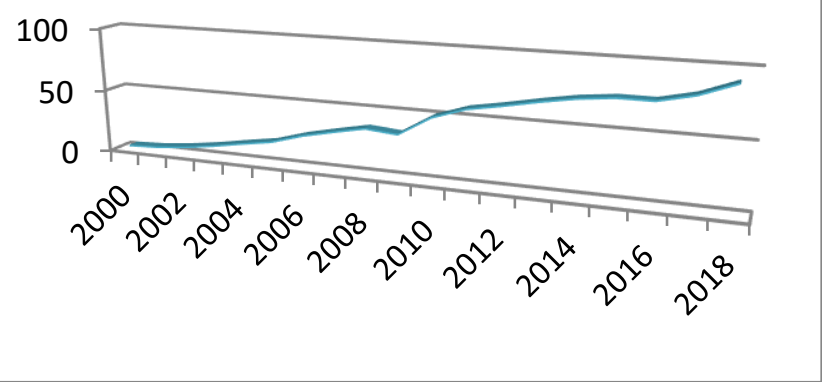

Source: Elaborated with data taken from COMTRADE

In 2012, China became the 4th largest export market for Mexico (1.5\% of Mexico exports) for the first time and remained the 2nd largest import market for Mexico (15.4\% of Mexico imports), in the same year exports were reported by $\$ 5.7$ billion and imports for $\$ 56.9$ billion, with a deficit balance of $\$-51.2$ billion and a total bilateral trade of $\$ 62.7$ billion. In 2015, China was the 3rd largest export market for Mexico (1.3\% of Mexico exports) and the 2nd largest import market for Mexico (17.7\% of Mexico imports) with exports that fell compared to those reported in 2012, being these by a total of $\$ 4.9$ billion, imports of $\$ 70.0$ billion, with a deficit balance of $\$-65.1$ billion and a total bilateral trade of $\$ 74.9$ billion.

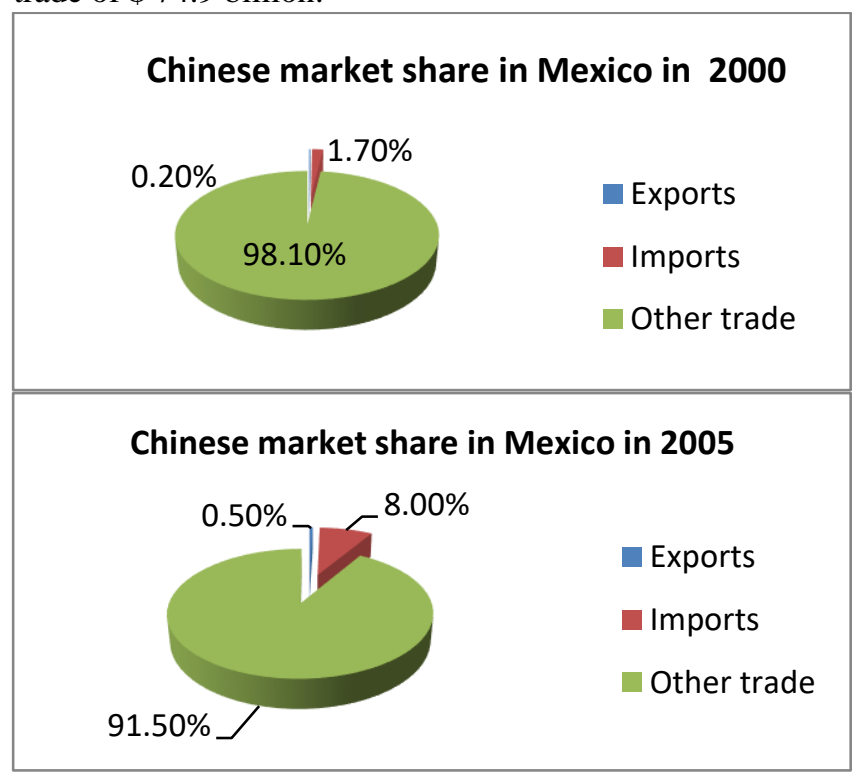

Source: Elaborated with data taken from COMTRADE

The last years of data reported by United Nations are 2017 and 2018. In both periods, China remained the 4th largest export market for Mexico and as the 2nd largest import market for Mexico, respectively, \$ 6.7 billion and \$ 7.2 billion were the export reports, imports were $\$ 74.2$ billion and $\$ 83.5$ billion, deficit balance were - $\$ 67.5$ billion and \$ 76.3 billion for each year, with bilateral trade of $\$ 80.8$ billion for 2017 and $\$ 90.7$ billion for 2018, having an increase of more than $\$ 10$ billion.

Published By:

Blue Eyes Intelligence Engineering \& Sciences Publication

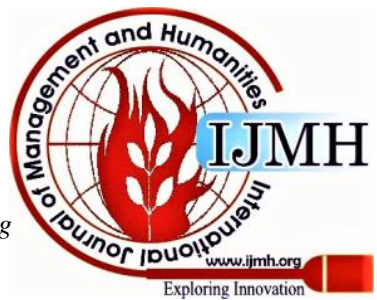




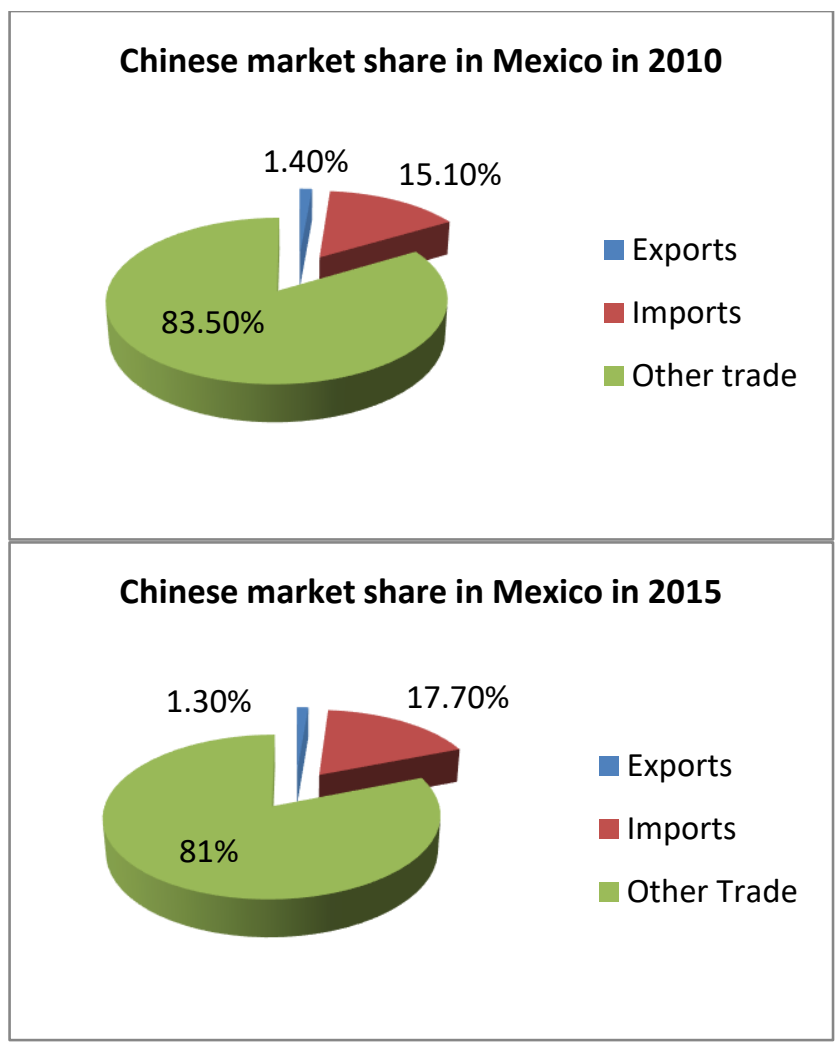

Source: Elaborated with data taken from COMTRADE

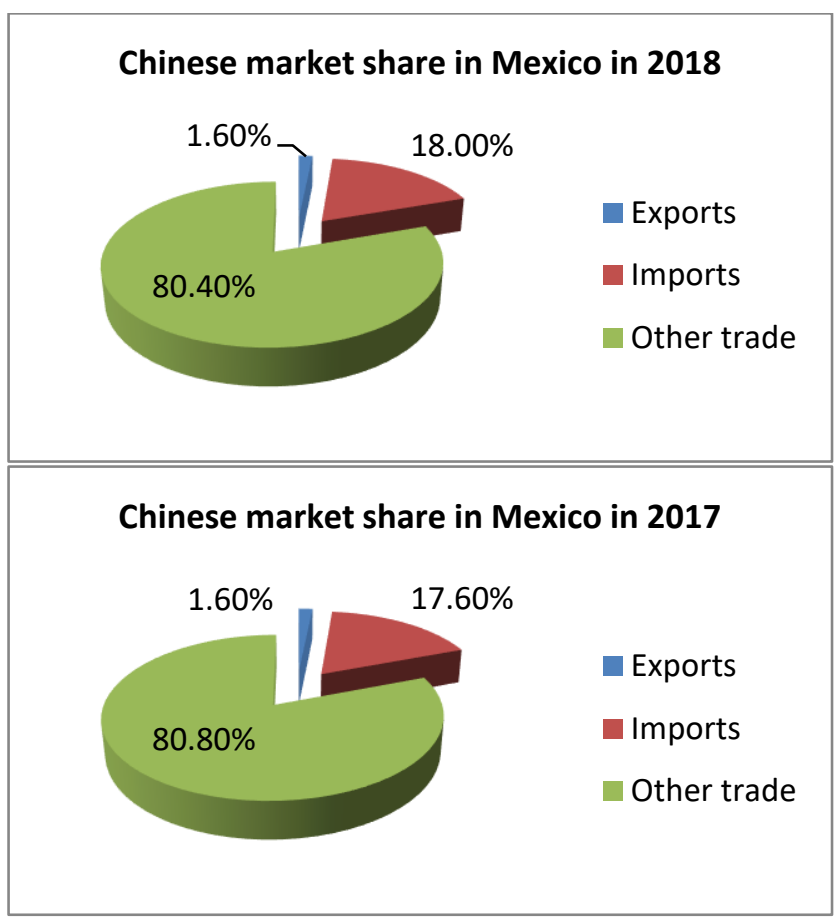

Source: Elaborated with data taken from COMTRADE

Overall the trade between Mexico and China in January of 2020 was 7 billion US\$, while in 2019 and 2018 was for over 90 billion USD. It is true that year by year the trade between these two partners is increasing but it also has carried a bigger gap in the trade balance, which since 1993 shows a deficit for Mexico.

\begin{tabular}{|c|c|c|c|c|}
\hline \multicolumn{5}{|c|}{$\begin{array}{c}\text { Balanza comercial de México con China } \\
\text { Valores en miles de dólares }\end{array}$} \\
\hline Año & Exportaciones & Importaciones & $\begin{array}{r}\text { Comercio } \\
\text { Total }\end{array}$ & $\begin{array}{r}\text { Balanza } \\
\text { Comercial }\end{array}$ \\
\hline 1993 & 44,777 & 386,442 & 431,219 & $-341,665$ \\
\hline 1994 & 42,162 & 499,655 & 541,817 & $-457,493$ \\
\hline 1995 & 37.002 & 520.580 & 557.582 & -483.578 \\
\hline 1996 & 38,277 & 759,704 & 797,981 & $-721,427$ \\
\hline 1997 & 45,882 & $1,247,376$ & $1,293,258$ & $-1,201,494$ \\
\hline 1998 & 105,977 & $1,616,494$ & $1,722,471$ & $-1,510,517$ \\
\hline 1999 & 126,338 & $1,921,057$ & $2,047,395$ & $-1,794,719$ \\
\hline 2000 & 203,586 & $2,879,620$ & $3,083,206$ & $-2,676,034$ \\
\hline 2001 & 281,774 & $4,027,253$ & $4,309,027$ & $-3,745,479$ \\
\hline 2002 & 653,913 & $6.274,381$ & $6,928,294$ & $-5,620,468$ \\
\hline 2003 & 974,369 & $9,400,591$ & $10,374,960$ & $-8,426,222$ \\
\hline 2004 & 986,304 & $14,373,843$ & $15,360,147$ & $-13,387,539$ \\
\hline 2005 & $1,135,544$ & $17,696,338$ & $18,831,882$ & $-16,560,794$ \\
\hline 2006 & $1,688,107$ & $24,438,279$ & $26,126,386$ & $-22,750,172$ \\
\hline 2007 & $1,895,338$ & $29,743,656$ & $31,638,994$ & $-27,848,318$ \\
\hline 2008 & $2,044,750$ & $34,690,310$ & $36,735,060$ & $-32,645,560$ \\
\hline 2009 & $2,207.788$ & 32.528 .967 & $34,736,755$ & $-30,321,179$ \\
\hline 2010 & $4,182,842$ & $45,607,551$ & $49,790,393$ & $-41,424,709$ \\
\hline 2011 & $5,964,225$ & $52,248,003$ & $58,212,228$ & $-46,283,778$ \\
\hline 2012 & $5,720,732$ & $56,936,129$ & $62,656,861$ & $-51,215,397$ \\
\hline 2013 & $6,468,508$ & $61,321,376$ & $67,789,884$ & $-54,852,868$ \\
\hline 2014 & $5,964,143$ & $66,257,292$ & $72,221,435$ & $-60,293,149$ \\
\hline 2015 & $4,873,152$ & $69,988,130$ & $74,861,282$ & $-65,114,978$ \\
\hline 2016 & $5,411,256$ & $69.521,795$ & $74,933,051$ & $-64,110,539$ \\
\hline 2017 & $6,712,580$ & $74,150,446$ & $80,863,026$ & -67.437 .866 \\
\hline 2018 & $7,428,917$ & $83,510,571$ & $90,939,488$ & $-76,081,654$ \\
\hline 2019 & $7,130,476$ & $83,052,518$ & $90,182,994$ & $-75,922,042$ \\
\hline $2020 / 1$ & 485,625 & $6,939,902$ & $7,425,5.27$ & $-6,454,277$ \\
\hline
\end{tabular}

\section{Exported and Imported Commodities}

Trade between China and Mexico is characterized by its focus on a few products. Mexico's major exports to China include ores, slag, ash, vehicles other than railway, electronic equipment, copper, nuclear reactors, boilers, beverages, plastics, optical products, as can be seen in the following chart. Nevertheless, in 2000 the main Mexican products exported to China were nuclear reactors, boilers, manmade staple fibers, electronic equipment, plastic, copper, and ores. Therefore, can be concluded that the variety of the Mexican exported products along 18 years has not changed, and the same products (just in different percentage) are still exported in 2018.

Mexico Top-10 exports of goods to China in 2018

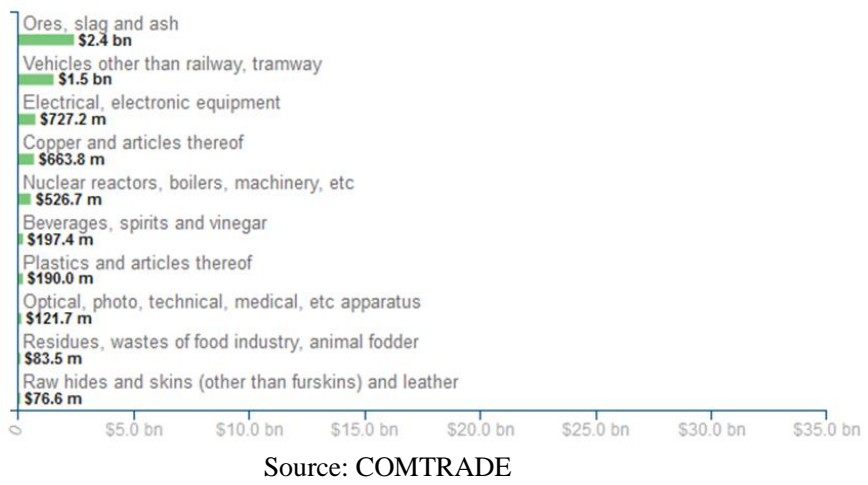

Mexico's imports from China in 2000 included electronic equipment, nuclear reactors, toys, games, sport requisites, optical apparatus, plastics, mineral fuels, organic chemical and so on. As it happened with the Mexican exports to China, the Chinese products imported to Mexico in 2000 were still being imported in 2018 (as it can be seen in the table below), so it can be suggested that the scope that these two trade partners have maintained has not change dramatically in the last almost twenty years.

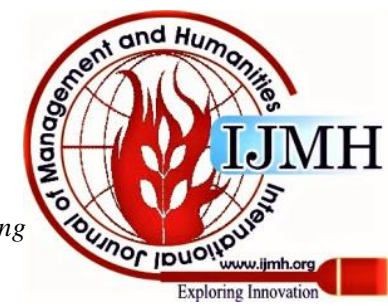




\section{Development of Trade Relations Between Mexico and China Under Non-Bilateral Trade Treaties}

Mexico Top-10 import of goods from China in 2018

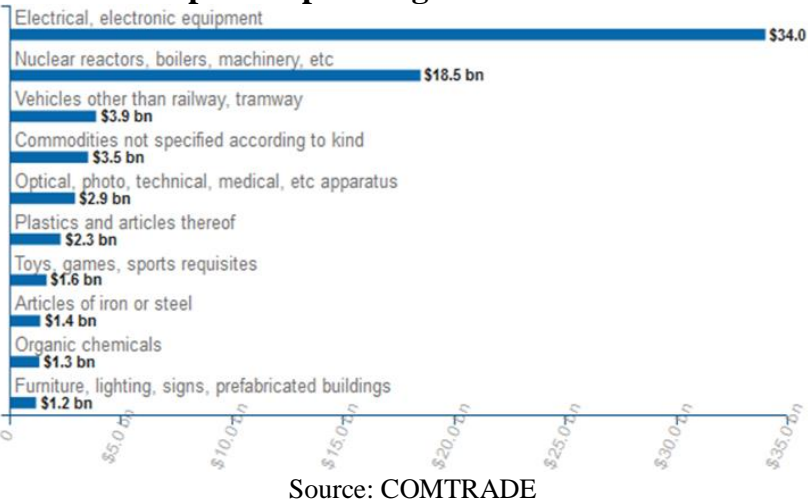

E. Differences in Trade Reports by Mexico and by China

Mexico's and China's trade structures are very similar, since the main exports of both countries are basically the same. This is the case in terms of electronics and auto parts, electrical parts and components, vehicles and mineral fuels/ petrol.

In the other hand it should be noted that there is a big difference in the trade figures reported by China and Mexico as a result of each country's method of compiling statistical information. In 2000, for example, Mexico reported a deficit of $\$-2.6$ billion, while China reported a deficit of $\$ 847.0$ million; in 2018 Mexico reported a deficit trade balance of 76 billon, while China in the same year reported 30.1 billion for the same concept. This is so, that if we keep moving on this way, the difference in the numbers reported by both countries will keep being there. The difference reported by these two countries is shown in the following chart.

Trade Balance difference according to Mexico and China's reports (From 2000 to 2018 in bn.)

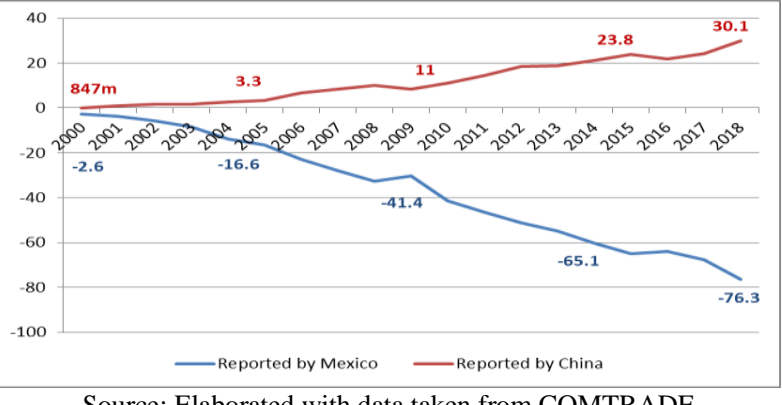

Source: Elaborated with data taken from COMTRADE

Compared to Mexico's calculations, China reported more imports of Mexican products in their national figures and a much lower level of exports to Mexico. This probably reflects the triangulation of bilateral trade through third economies (Hong Kong, Singapore and the United States) (Dussel Peters 2005a: 50-61).

It is a fact that the rapid expansion of China in the global market has complicated Mexico's economic and commercial circumstances. In the last 20 years, its trade deficit with China (and with the East Asia region) has increased significantly. Although this deficit has been offset by Mexico's surplus with other regions (especially with North America), it has created great uncertainty and fear in Mexican economic sectors, in particular those that have lost their domestic and foreign markets.

China's demand for agricultural goods, food and beverages has led to Mexico's growing trade deficit in the following commodities: corn, soybeans, wheat, sorghum, rice, rapeseed, and others. This is significant since China and Mexico's trade structures are very similar - with the exception of minerals and several other raw materials - but presents structural limitations to increasing trade in the sectors that experience a high demand both in China and Mexico, such as oil and grains. In the other sectors (electronics, auto parts, and increasingly automobiles), there is high potential for direct competition (Dussel Peters 1995a: 18-21).

\begin{tabular}{ccc}
\hline Year & $\begin{array}{c}\text { Reported by Mexico in } \\
\text { bn. USD }\end{array}$ & $\begin{array}{c}\text { Reported by China in } \\
\text { bn. USD }\end{array}$
\end{tabular}

\begin{tabular}{lcccc}
\hline & Exports & Imports & Exports & Imports \\
\hline 2000 & $310.2 \mathrm{~m}$ & 2.9 & 1.3 & $488.3 \mathrm{~m}$ \\
2001 & $384.8 \mathrm{~m}$ & 4.0 & 1.8 & $761.3 \mathrm{~m}$ \\
2002 & $653.7 \mathrm{~m}$ & 6.3 & 2.9 & 1.1 \\
2003 & $974.3 \mathrm{~m}$ & 9.4 & 3.3 & 1.7 \\
2004 & $473.7 \mathrm{~m}$ & 14.4 & 5.0 & 2.1 \\
2005 & 1.1 & 17.7 & 5.5 & 2.2 \\
2006 & 1.7 & 24.4 & 8.8 & 2.6 \\
2007 & 1.9 & 29.7 & 11.7 & 3.3 \\
2008 & 2.0 & 34.7 & 13.9 & 3.7 \\
2009 & 2.2 & 32.5 & 12.3 & 3.9 \\
\hline 2010 & 4.2 & 45.6 & 17.9 & 6.9 \\
2011 & 6.0 & 52.2 & 24.0 & 9.4 \\
\hline 2012 & 5.7 & 56.9 & 27.5 & 9.2 \\
\hline 2013 & 6.5 & 61.3 & 29.0 & 10.2 \\
2014 & 6.0 & 66.3 & 32.3 & 11.2 \\
\hline 2015 & 4.9 & 70.0 & 33.8 & 10.0 \\
\hline 2016 & 5.4 & 69.5 & 32.4 & 10.3 \\
\hline 2017 & 6.7 & 74.2 & 35.9 & 11.8 \\
\hline 2018 & 7.2 & 83.5 & 44.1 & 14.1 \\
\hline & Source: Elaborated with data taken from COMTRADE
\end{tabular}

It is significant to highlight that Mexican exports, as in the Chinese case, highly depend on foreign inputs and foreign firms. From 1993 to 2004, 78.02 per cent of Mexican exports depended on temporary imports that were reexported. This trade structure reflects the low level of domestic value added onto exports and the difficulties of Mexican manufacturing in achieving a positive trade balance (Dussel Peters 1995a: 21-23).

Total of Bilateral Trade difference according to Mexico and China's reports (From 2000 to 2018 in bn.)

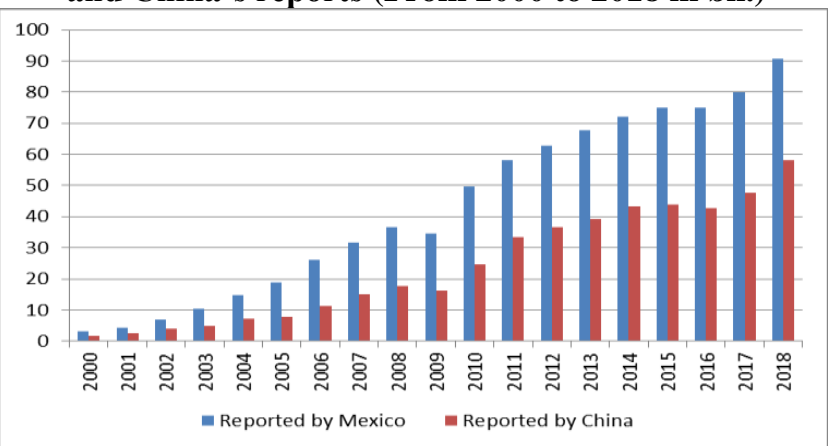

Source: Elaborated with data taken from COMTRADE

\section{Published By:}

Blue Eyes Intelligence Engineering $\&$ Sciences Publication

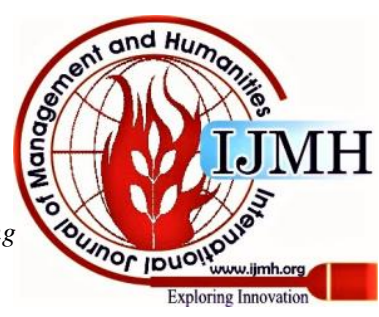


As summary, throughout history, the trade volumes between Mexico and China have had drastic ups and down. This has been caused by domestic political factors as well as changes in the international political system.

The commercial relationship between Mexico and China (and consequently, their production relationship) is complex and difficult. In Mexico, there are concerns in sectors of manufacturing about the role of China in world trade and especially about the trade relationship between the two countries.

The problem of Mexico's trade deficit with China and by extension with East Asian countries goes beyond government strategies. The flow of goods and services often depends on the requirements of transnational corporations (TNCs). This is because the interests of global corporations may not be aligned with the development policies of national economies, specifically on the production facilities, capital and transfers mobility, and intra-firm trade, which are out of the government's control.

Therefore, it is not only necessary to evaluate the development of bilateral relations in recent years but it is also necessary maintain steady political relations and promote economic cooperation during the rest of the current administration of Mexican president, Andrés Manuel López Obrador with the Chinese leader Xi Jinping. It is important to mention that what Mexico has to consider is how to lay a solid foundation for bilateral relations to be prosperous in the long term. Furthermore, given the global economic situation and the particular ones of China and Mexico, there is a good opportunity for the two countries to achieve solid economic cooperation, with full use of existing mechanisms and measures at the regional and bilateral level.

\section{IV.MEXICO AND CHINA TRADE RELATIONSHIP'S SWOT}

\section{A. Strengths}

\section{i) Integral Strategic Association}

Although the link began in the 19th century, diplomatic relations between Mexico and China were established on February 14, 1972, after the Mexican government joined the vote in favor of China to join the United Nations (UN) as the sole representative of that nation and accepting the principle of "one China" based on the recognition of the indivisibility of its territory, in October 1971.

Both Mexico and China have created various institutions in order to improve their bi-national relationship; thus, there is the Mexico-China Bi-national Commission, created in 2004; the High Level Group of 2005; the High Level Business Group and the High Level Group on Investments, both from 2013. Since 2003, China has described the links with Mexico as a "strategic relationship" and in 2013 it rose to a rank of "Integral Strategic Association", although there is no exact clarity about what is the meaning of it, what does this qualifier imply or what does it refer to, the truth is that there is a close relationship between Mexico and China, not only because of the relationship that Mexico has with the main competitor of China, the United States, but also due to the trade deficit that Mexico maintains with China; reason why

the qualification of Integral Strategic Association, which in itself denotes positive aspects in the relationship, it should be addressed and materialized in the Mexico-China relationship.

Now, the range of the relationship between China and Mexico is the result of the diplomatic relationship that these two countries have maintained throughout the years. Since the establishment of formal diplomatic relations, with the exception of the current president, all the presidents of Mexico have visited China. Although it is true that there is no express declaration to which the level of a "Comprehensive Strategic Association" refers, it is evident that China considers the relationship to be strategic, not only due to its proximity to the US market, but also due to the fact that that a large part of the Central American countries, neighbors of the Mexicans, continue to maintain diplomatic relations with Taiwan. More recently, given that Beijing has sought agreements with Taipei, the possibility that Mexico influence Central American governments to change their position on China would not be surprising. ${ }^{15}$

Within the framework of the aforementioned Integral Strategic Association, many dialogue mechanisms have been established at almost every level of the relationship. During the presidency of former President Enrique Peña Nieto, he met with President $\mathrm{Xi}$ Jinping seven times between mutual visits and meetings in multilateral forums. Showing the mutual interest of both nations to continue building and maintaining the comprehensive strategy they uphold.

Likewise, Mexico, along with Peru, was very protagonist in China's aspiration to have a regional dialogue mechanism. In this way, the Forum of the Community of Latin American and Caribbean States (CLACS) with China was established. Its first annual meeting was held in Beijing on January 8 and 9, 2015, with several sub-forums for specific areas: Forum of Chinese Agriculture Ministers, Forum of ScientificTechnological Innovation, China-Latin America and the Caribbean Business Summit, Forum Think Tanks Exchange Forum, Young Politicians Forum, Infrastructure Cooperation Forum, Political Parties Forum, China-Latin America and Caribbean Civil Society Friendship Forum. In addition, at the most recent meeting in 2018, China offered the region the investment benefits of its "One Belt One Route" project, on which an agreement was signed. Regardless of the effectiveness of CLACS, this has been an important space in which such a fragmented region has come together without the presence of the United States and Canada, which in China's rational perspective is an important mechanism for reaching agreements with the region, and so with Mexico.

\section{ii) Mexican Integration with the US Economy}

\footnotetext{
${ }^{15}$ Cornejo, Romer: "Mexico and China's competitiveness, China and Latin America, New approaches to cooperation and development, A second Silk Road?" Intal, Buenos Aires, 2005, p. 239.
}

Published By:

Blue Eyes Intelligence Engineering \& Sciences Publication

(C) Copyright: All rights reserved.

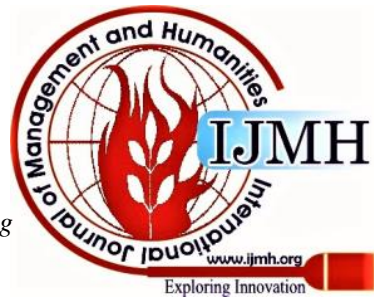




\section{Development of Trade Relations Between Mexico and China Under Non-Bilateral Trade Treaties}

Mexican integration with the US economy provides the perfect gateway for Chinese businesses to strengthen access to the US market. It's no secret why China-Mexico relations are strengthening. While China's manufacturing boom is slowing down, Mexico's remains vibrant. Chinese companies setting up operations in Mexico can expect closer and more integrated access to US markets for similar costs. And Mexico has made great strides in the recent past to sweeten the deal.

In this order of ideas, for China and other international competitors, it just makes sense to manufacture next to the largest consumer market in the world. Time is reduced between production and sale, inventory levels are reduced by a shorter time to market, transport costs are reduced due to less time in transit, and collaboration between manufacturing staff and design and management staff who may be in the US is made simpler.

Therefore, Mexico has the potential to attract more Foreign Direct Investment not only from China but also from other parts of the world; its location and the historical relationship that it has maintained with United States are a key in term of international trade.

\section{iii) Mexico Foreign Trade Agreements}

In addition to providing access to the US consumer market, Mexico offers access to virtually every regional market in the world, with a network of 13 Free Trade Agreements with 52 countries (FTAs), 32 Agreements for the Promotion and Reciprocal Protection of Investments (APPRIs) with 33 countries and 9 agreements of limited scope (Economic Complementation Agreements and Partial Scope Agreements) within the framework of the Latin American Integration Association (ALADI), all of them valid. ${ }^{16}$

\section{iv) Complementary trade}

According to what was analyzed in the previous chapter, there are areas in which the advantage that China has over Mexico in terms of the products and services that these two countries import and export is evident; in the same way there are products in which a high degree of competition is observed; However, there are also areas in which the trade they carry out is complemented, or can be complemented each other, such is the case of the automotive products manufacturing sector, in which Mexico has a comparative advantage over China, occupying the third place worldwide as an exporter of auto parts, or fourth place if the European Union is considered as an economic entity, leaving China in position six and seven, respectively. This fact reveals an industry that has the potential to export to China and that could help Mexico reduce the deficit trade balance that it has with respect to the Asian country.

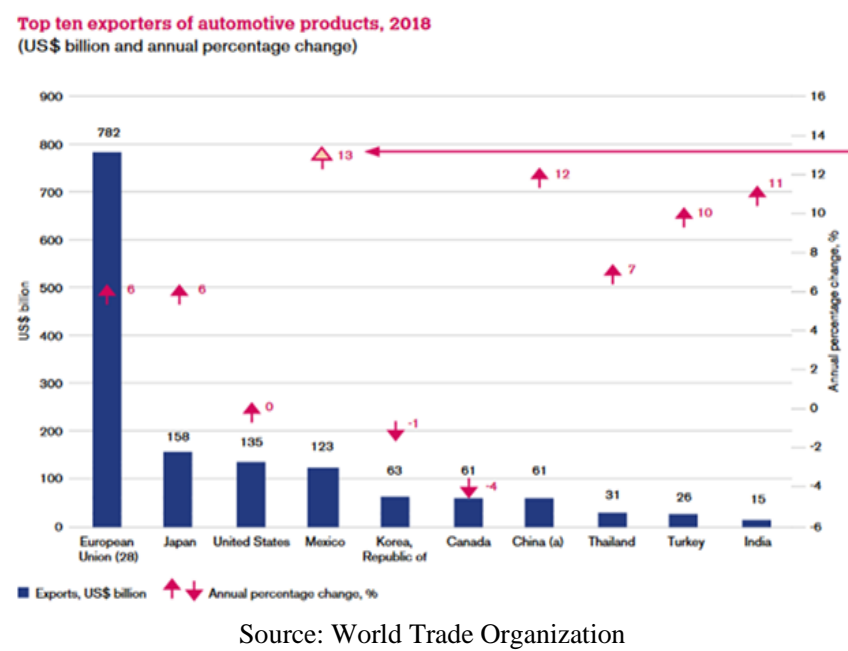

In the same way as regards the agriculture sector, both China and Mexico are among the ten largest exporters, so it can be said that agriculture is an industry in which these two countries are competitors, which is so to a certain extent, because the products they import and export are complementary among these two countries. For instance, Mexico exports avocado, fruit and tequila to China, among others, while China's exports to Mexico do not stand out for being mainly in products from the agricultural industry, but products from the manufacturing sector. In other words, it can be concluded that some of the products these two countries exchange are complementary but with respect to other they are clearly competitors. A clear example of this is the manufacturing sector in which China is the world leader, however, in a subdivision of this category, which includes a great diversity of by-products, this is, manufacture of automobile products Mexico has a comparative advantage over the Chinese market.

Top ten exporters of agricultural products, 2018
(US $\$$ billion and annual percentage change)

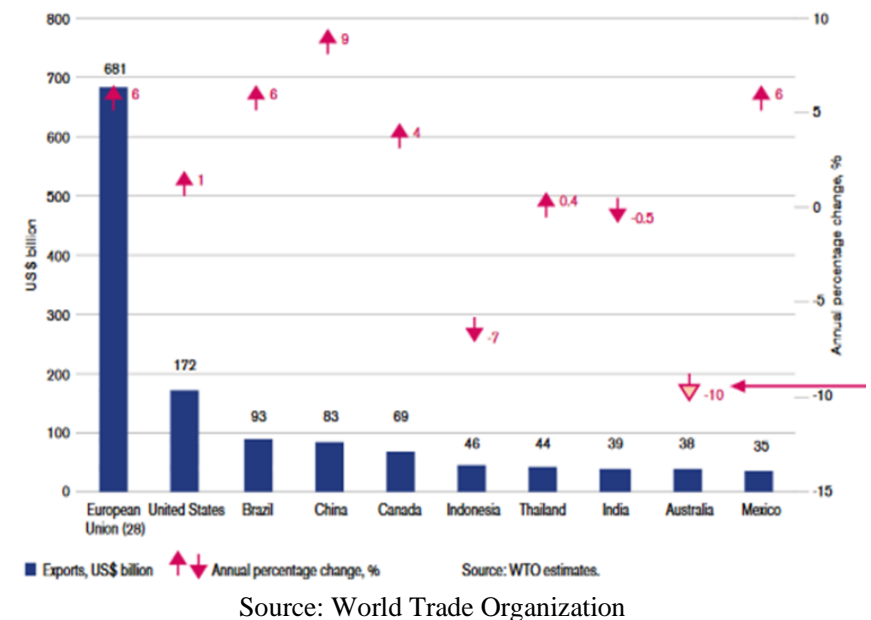

Likewise, the fact that China has changed its offer of products becomes relevant, now it seeks to produce hightech and value-added products, such as electronics and computer parts and accessories, which also alters its consumption chain, representing an opportunity for Mexico, since there will be a greater demand for basic and intermediate products in order to satisfy the needs of their new production chains.

\footnotetext{
${ }^{16}$ Source: Mexican Ministry of Economy. Consultation made on its official
$\begin{array}{lll}\text { website on January } & \text { 22, 2020. https:/www.gob.mx/se/acciones-y- }\end{array}$

${ }^{16}$ Source: Mexican Ministry of Economy. Consultation made on its official
website on January 22, 2020. https://www.gob.mx/se/acciones-yprogramas/comercio-exterior-paises-con-tratados-y-acuerdos-firmados-con$\underline{\text { mexico }}$
}

Published By:

Blue Eyes Intelligence Engineering

\& Sciences Publication

(C) Copyright: All rights reserved. 


\section{v) Mexico as a manufacturing country}

While China and other Asian countries have been the destination for many manufacturers in recent years, Mexico has been steadily increasing market share and is swiftly becoming the partner of choice for manufacturers who might otherwise have invested in Asia. This shift not only means that global manufacturers are choosing to manufacture in Mexico instead of Asia, but also that Chinese and other Asian firms are moving their manufacturing to Mexico as well.

As an example of this, there is Lenovo Group Ltd., whose in 2007 ramped up its PC production by spending US\$20 million on a new manufacturing and fulfillment plant in Mexico, with this Lenovo made the investment over a five-year period. The Monterrey, Mexico, facility was open in mid-2008. It represented Lenovo's largest manufacturing investment outside of China, capable of producing five million PCs annually. It employed 750 staff and supply computers to the Americas with the exception of Brazil, where Lenovo maintains its current relationship with a local partner. Lenovo decided on the Monterrey location after running a lot of complex simulations.

The simulations were based on a wide range of factors including the company's desire to create an end-to-end supply chain and deliver its products to customers on a timely basis as well as the size of the available labor pools. Later in 2018 Lenovo Group Limited invested US\$ 20 million at its plant located in Apodaca, Nuevo Leon, Mexico in order to add five production lines over the next eight months. Along with the investment additional job positions were opened to hence the total workforce and the facility increased from 1,164 workers to nearly 2,000.

One more example of Mexico's global position as strategic manufacturing place is Anhui Jianghuai Automobile (JAC Motors), which together with the Mexican Giant Motors 50\% owned by Carlos Slim -, invested more than 4,400 million pesos (\$213 million at the exchange rate of the investment date) in a plant in Hidalgo, Mexico.

These two companies are not the only ones many other Asian multi-national corporations are following this trend. This is demonstrated even in industries viewed as strongly Asia-centric, such as electronics. A 2014 report from the Boston Consulting Group pointed out that a full third of electronics-industry investment in Mexico is now coming from Asian companies like Sharp, Sony, and Samsung. Even Japanese automakers are moving production to Mexico.

In the specific case of China, one of the reasons why this is occurring is because Chinese companies are searching for ways to save costs as the price of their labor is steadily rising, at the same time, experts generally agree that Mexican labor is more productive than labor in Asian countries, effectively reducing production costs due to increased output.

Moreover, manufacturing in Mexico allows Asian manufacturers to more thoroughly protect intellectual property. Conversely, IP laws in Asian countries are far more porous, additional to have more efficient (in time and cost production) access to the United States and all Latin America market.

\section{B. Weaknesses}

\section{i) Unequal Relations}

Although it is true that greater commercial exchange offers greater opportunities for development, and it is also true that the conditions under which such trade occurs are relevant; since only under suitable conditions a win-win relationship would be possible. However, reality and practice is more prosaic, for many countries these conditions are not yet reached due to their unsolved internal problems, the policies adopted by their governments in the foreign trade field, their technological development or under development and by the external events and vicissitudes that occur in the world.

The Mexico-China relationship has taken place in this dynamic, where the trade relations between the two countries has been intensifying in recent years, to the point that China has clearly benefited but Mexico has not yet achieved the same. Probably the reason which can explain this is that since 1978 China a centrally planned economy; while Mexico change policies and directions every new administration arrives to the presidency adopting different ways to try to solve the Mexican internal problems, but until today, those have not been yet addressed properly.

Although these are two developing countries, relations between Mexico and the People's Republic of China (RCP) have been uneven. In recent years, coinciding with the dizzying rise of the Asian country, this inequality has increased. The trade balance between the two countries is clearly in deficit for Mexico, showing a deficit of \$75 billion dollars in 2019, unlike the trade that Mexico maintains with the United States, with whom in 2019 it registered a surplus of $\$ 101$ billion ${ }^{17}$. Even though Mexico and the People's Republic of China (RCP) are developing countries, the relations they have historically maintained are characterized by inequality. This inequality today has been accentuated like never before, especially in the economic field. In this sense, it would be necessary to analyze how to trade with China, since it is enough to see the size of the economies of China and Mexico to know that the conditions in which they interact in the international framework are unequal.

The accelerated growth of Chinese exports to Mexico reflects, in part, the uneven growth rate that both economies have registered in recent years. Between 1980 and 1990 China grew at a rate of $9.2 \%$ on an annual average and Mexico at 2.5\%; while from 1991 to 2000 decade China growth rate was at $10.1 \%$ and the Mexican growth rate was at $3.5 \%$ and from 2001 to 2005 the growth rate annual average in these economies were 8.6 and 1.9 percent, respectively. Even though in recent years China has had an economic slowdown, in 2019 it had a growth of 6.1, while

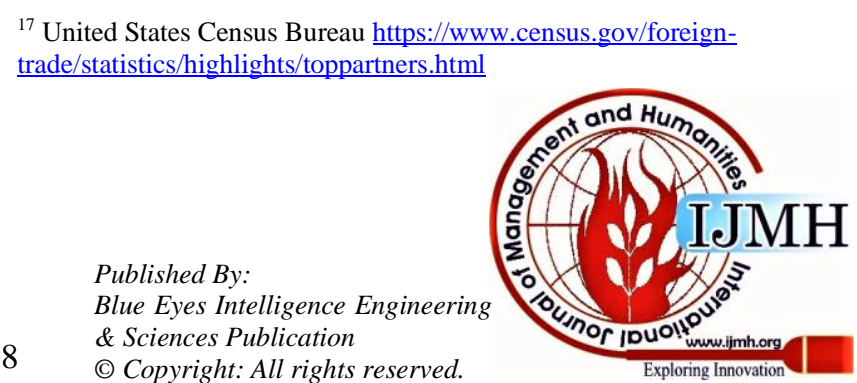




\section{Development of Trade Relations Between Mexico and China Under Non-Bilateral Trade Treaties}

in the same year the Gross Domestic Product (GDP) of Mexico fell to $0.1 \%$ according to data from the National Institute of Statistics and Geography (INEGI). This is the first time in ten years that the growth of Latin America's second economy is negative, something that had not happened since 2009 when Mexico recovered from the global economic crisis.

Such economic and commercial inequality; however, should not be a reason to not seek a commercial exchange between these two countries, on the contrary, an intelligent commercial exchange should be sought that adapts to the needs and capacities of each country, especially in the case of Mexico if its goal is to reduce the trade deficit with China and at the same time have in China a trading partner from which can learn and benefit, economically speaking.

The development of both, Mexico and China in science and technology is important to strengthen relations between the two countries. Although it is true that this type of knowledge is considered key to the strategic development of a country, it is also true that the lack of scientific and technological exchange generates a disadvantage and a probable lag. For this reason, it is important to create a bridge or mechanism through which it is certain that there are equitable conditions for the participants, and that the exchange of information is done in an official and professional manner, always in compliance with international regulations on intellectual property.

\section{ii) Political Misunderstandings}

Since the past presidential administrations in both China and Mexico, unfortunately political disagreements have been part of the relationship between these two countries. Among some events that can be listed are the fact that the government of Felipe Calderón took as a slap the reaction of China during the H1N1 influenza crisis, in which Chinese authorities quarantined an airplane of the Mexican airline Aeroméxico and the passengers who were traveling in such aircraft. Another political disagreement that damaged the bilateral relationship between China and Mexico was the meeting that former Mexican President Felipe Calderón held with the Dalai Lama, who visited Mexico on that occasion, which caused the relationship with China to fall to a negative status at that time, being one of its lowest levels since relations between the two nations were established in 1973.

In summary, during Felipe Calderón's presidency, it is evident that he lacked the political will to achieve a greater rapprochement with China, both politically-strategically and commercially-economically. What should be taken into account when analyzing the China-Mexico relationship, and especially when making proposals to improve the relationship between these two nations, since for this to happen, the will at a high level must be a priority policy implement.

Then again, during the next presidency of Mexico, the presidents of both nations held significant meetings on various occasions, showing the relationship between China and Mexico to be part of their agenda. As part of their mutual interest, from 2012 to 2018, 12 bilateral agreements were signed in different areas of trade in order to give a further boost to trade. However, during the same presidential term, projects in which China was involved were canceled by the Mexican government, which again caused the China-Mexico relationship to drop in level and Chinese investments to be lost.

One of the projects referred to is the Dragon Mart shopping center, a project that was planned to build a shopping center with Chinese and Mexican capital in southern Mexico; however, the Mexican environmental authority canceled the permit that had been granted and through which the construction of the same center began to be built, pointing out that with such construction the Mexican ecosystem was damaged, so at first the building permit was illegally granted by another authority. Besides the Dragon Mart shopping center, one more case also cancelled in Mexico due to corruption, the Bullet Train project; a decision that had already been taken and announced about the tender project for the fast train to Querétaro, which had been won by a Chinese state company. Consequently, these two failed projects have affected the China-Mexico relationship, and what was initially perceived as a renewed understanding between Mexico and China ended up being a mismatch in terms of trade and foreign investment between these two countries.

More recently, within the framework of the current presidency of Mexico, no presidential visits have been carried out, in fact in the Mexican National Development Plan 2018-2024, China is not mentioned at all, which shows the absence of a foreign policy towards China, the second largest trading partner Mexico and the country with which Mexico had a trade deficit of \$ 75 billion in 2019.

In conclusion with regard to political disagreements, these have not only been frequent, but even worse, that this situation affects the mood of both countries and generates unnecessary obstacles in the attempt to improve the economic relationship, especially for Mexico.

iii) Absence of a foreign policy of Mexico with respect to China and/or its continuity

In relation to the immediate previous point, and as part of the final comments, this weakness point makes sense. China's interest in Mexico, unfortunately, does not appear to have a clear counterpart from the Mexican government. At the time, the National Development Plan 2007-2012 prepared by the Felipe Calderón government referred to the need to build "strategic alliances" with Asia, in addition to taking advantage of the platform offered by the Asia Pacific Economic Cooperation Forum (APEC) to strengthen ties with its members. However, China was barely mentioned in the following terms: «Take advantage of the platform of the Asia Pacific Economic Cooperation Forum (APEC) to derive governmental and business agreements with the countries of the Pacific Rim, and strengthen ties with China, Japan, India, Korea, Singapore, Australia and New

Published By:

Blue Eyes Intelligence Engineering
\& Sciences Publication

(C) Copyright: All rights reserved.

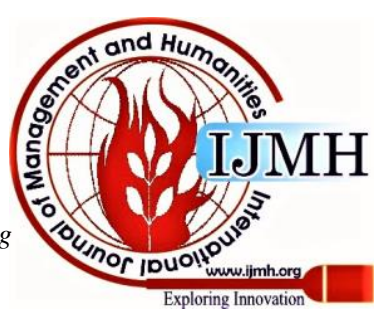


Zealand." ${ }^{18}$ As can be seen, the reference to China was very brief and superficial, with mentioning a specific policy or plan to address.

Years later, Mexico's relationship with China in the 20122018's presidency had no important changes compared to previous government. Mexico continued with the policy of not considering the presence of China in the international community, neither the characteristics of its political system nor its major economic projects. Although relations between both countries began with the slogan of "re-launch", they were affected by the failures of Chinese economic projects in Mexico. Diplomatic relations continued their normal course, with meetings between officials of various levels and the signing of interesting cooperation agreements. For its part, China maintained an effective cultural policy of creating favorable public opinion among academics, politicians and the media.

At the time, the aforementioned plan presented a mediumlong-term vision, referred to as the "2030 vision", what suggested continuity for the next 20 years. But that vision is not guaranteed by the Mexican government, largely because, with each change of government, the new authorities seek to stamp their "proper seal" on the policies. This would not be reprehensible in cases where the preceding policies were erroneous, but with respect to those that have been successful, the same criterion of "six-year reinvention" usually applies. Apparently, only in the commercial and investment planes with the US there is a continuity, due to the commitments made in the North American Free Trade Agreement, today the United States, Mexico and Canada Agreement (USMCA), whose lack of compliance by Mexico would entail unacceptable political and economic costs for Mexico. In any case, the situation in Mexico is different from the situation in China, which does have a national project under which the five-year plans operate and whose continuity is guaranteed despite the dissent and divergent opinions that naturally exist in the high levels of political spheres of that country.

Continuing with this line of analysis, in the Mexican Government's National Development Plan (PND) 2013$2018^{19}$, China was first mentioned as the cause of the increase in food prices due to the increase in its demand, which affected, according to the Plan, in increasing the price of the basic products in Mexico. Likewise, reference is made to the competition of China's labor force since that country's entry to the World Trade Organization (WTO), as one of the causes of the low competitiveness of the Mexican labor force; although it recognizes that the recent increase in wages in the Asian country could benefit Mexico. Likewise, it recognizes the need to attract tourism from China and affirms, in the vaguest possible way, that "Mexico has the challenge of taking relations with that country towards a new paradigm of cooperation and dialogue, which allows for

\footnotetext{
${ }^{18}$ National Development Plan 2007-2012, Presidency of the Republic, Mexico, 2007, available at http://pnd.presidencia.gob.mx/.

${ }^{19}$ See full text, Government of the Mexican Republic, National

Development Plan 2013-2018. Official Gazette of the Federation, May 20, 2013,http://www.dof.gob.mx/nota_detalle.php?codigo=5299465\&fecha $=20$ $\underline{105 / 2013}$
}

Retrieval Number: J09580641020/2020@BEIESP

promoting new schemes of understanding and exchange", however, this is a statement that can be said in regard to every country in the world.

In this context, once again, Mexico's relationship with China can be characterized by being made up of, 1) a country that lacks a clear definition of its foreign policy based on its major internal problems and international projection, and 2) with a country that starts from the solution of its internal affairs, perfectly defined, and with precise plans in the medium and long term regarding its position as a global power. The administration of the Mexican government, as in the past, does not take actions that are sustainable and close to reality regarding its trade relationship with China.

\section{iv) Ignorance of the Chinese market}

The perception that various Mexican businessmen have about China is that it is a "difficult" and remote market, where language functions as an insurmountable barrier and that is part of the reason why most choose the US market, considering it close and better known.

It should be noted that, in order to develop relations with any region or country, it is necessary to promote their study. However, studies on China are scarce in Mexico. Most of the publications circulating in the country refer to economic aspects, in particular to unfair commercial practices, leaving aside a deeper analysis about the evolution of the Chinese economy and politics. This ignorance explains many of the attitudes of business and government actors in their relations with China. Therefore, studies on that nation would help to glimpse desirable and possible policies for a potentially more beneficial approach between the two countries.

\section{v) China seen as a threat to Mexico}

China's arrival at the World Trade Organization (WTO) was contested by Mexico base on unfair competition and dumping, and in 2001 Mexico was the last country to withdraw these objections, imposing countervailing duties and tariffs on various products.

These measures were due to frictions in similarities of export structures in sectors such as: electronics, auto parts, fuels, low wage costs and highly developed manufacturing companies. Even with these precautionary measures, the Mexican maquiladora industry was overwhelmed by China's production, which caused the loss of 250,000 jobs during the first years of the new millennium, where Foreign Direct Investment (FDI) fell from \$ 29 billion in 2001 to 18 Billion dollars in 2003.20

It is because of the reasons given here that the negative effect that Mexico visualized in the face of the Chinese presence, its rules and its unfair practices is justified. Although it is true that in 2020 the perception of China in Mexico has improved, it is also true that it is still not possible to visualize in a general way the opportunities that

${ }^{20}$ At Mexican Ministry of Economy http://www.economia.gob.mx/files/comunidad_negocios/comision_naciona l/2012 i.pdf.

Published By:

Blue Eyes Intelligence Engineering

\& Sciences Publication

(C) Copyright: All rights reserved.

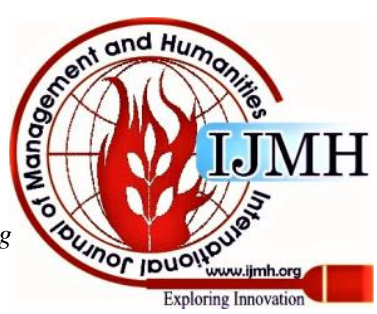




\section{Development of Trade Relations Between Mexico and China Under Non-Bilateral Trade Treaties}

trade with this nation represents, therefore, as long as this situation does not change, the trade balance will hardly reduce for Mexico.

In December 2011, the shielding relationship entered a new phase, when the compensatory quotas imposed by Mexico expired, a situation that helped to increase its bilateral efforts and improve its commercial relations by seeking joint investment opportunities in projects that have not yet been successful for Mexico. It should be noted that from 2012 to 2015, the Mexican steel industry once again suffered from excessive competition from the Chinese market, which led Mexico to apply anti-dumping policies again, due to the low price of steel that China offered against Mexican steel. , which led Mexican companies to close operations, as they were not competitive in the global market.

In this regard, Mexico continues to see China as a threat, instead of seeing the Asian giant as an alternative growth opportunity from the United States. Competitive advantages, such as its dense population, represent one of the largest commercial markets. According to the Organization for Economic Cooperation and Development (OECD), in 2030 the emerging middle class of China will expand, being one of the determining factors of social change in consumption patterns oriented towards durable goods, health, education and tourism; that is, the rise of a middle class with demand power, which, if taken advantage of by Mexico, could become the extension of a market niche; however, for this to occur, the perception of a Chinese threat must change and be taken as opportunities.

\section{vi) Foreign Investment}

According to statistics from the Chinese Ministry of Commerce, China's direct investment flow to Mexico was 378 million US dollars, but by the end of the same year, 2018, the stock of Chinese direct investment in Mexico was $\$ 1,107$ billion. Nevertheless, according to statistics from the Mexican Ministry of Economy, China's direct investment in Mexico in 2018 totaled US \$ 250 million. This accounted for $0.8 \%$, an increase of $9.7 \%$ compared with 2017 .

China's investment stocks from 1999 to 2018 in Mexico were 1.445 billion US dollars, accounting for $0.2 \%$ of the total of Chinese investment.

By the end of December 2018, at the Chinese Embassy in Mexico there were nearly 100 Chinese-funded enterprises registered in areas such as communications, manufacturing, finance, etc.

According to statistics from the Chinese Ministry of Commerce, in 2018 Chinese companies signed 35 new contracts in Mexico, those contracts summed up 1.276 billion US dollars, completed turnover of 554 million US dollars. In the same year a total of 53 professionals from different areas were assigned from China to go to work in the respective Chinese companies in Mexico and thus, by the end of the year there were in total 325 new assignments. Among the signed large projects were taken by Huawei Technologies Co., Ltd. in the Telecom industry; Shenyang Yuanda Aluminum Engineering Co., Ltd. signed a contract for the terminal of the New International Airport in Mexico City; additionally, China Hong Kong Company signed contracts in Veracruz, Mexico for the third bidding section of the a port project: house construction projects and others. Notwithstanding these investments, being Mexico the second largest economy in Latin America, it is striking that in the last "Report on Development of China's Outward Investment 2018" published by the Chinese Ministry of Commerce 21, it hardly mentions Mexico as another participant of foreign investment from China, being under the levels of investment that Latin America countries receive from China. Therefore, the investment received by China in Mexico in less than what other countries of the region received, what puts Mexico's attraction of FDI from China under countries such as Cayman Islands, the British Virgin Islands, Venezuela, Brazil, Argentina, Ecuador, Jamaica, Peru and Trinidad and Tobago. This should be an area of opportunity in which Mexico must work, although it is true that China has reduced its investment in Latin America, it is also true that it continues investing in Latin America region, that's why Mexico has to implement fiscal policies to attract a greater proportion of that investment if its aim is to reduce the trade deficit that it currently has with China.

\section{vii) Trade Composition}

The composition of trade between both countries is dictated by the characteristics of their economies; both seek to place processed products in the foreign market, so there is undoubtedly more than one industry in which they are competitors, among which the manufacturer stands out, specifically with respect to telecommunications and office equipment, as can be seen in the following graphs. However, China has an obvious comparative advantage over Mexico in this regard, given its enormous industrial development and its investment in science, technology and development; reason why Mexico has to diversify its market with China, not only because they are competitors, but because the range of products that these two countries have been exchanging over the years has not shown any substantial change that allows Mexico to reduce its trade deficit with China, but on the contrary, a large number of the products that Mexico exports to the United States are manufactured with raw materials that it imports from China, which at the same time explains that its trade balance with China is in deficit, but the balance trade with the United States reports a surplus.
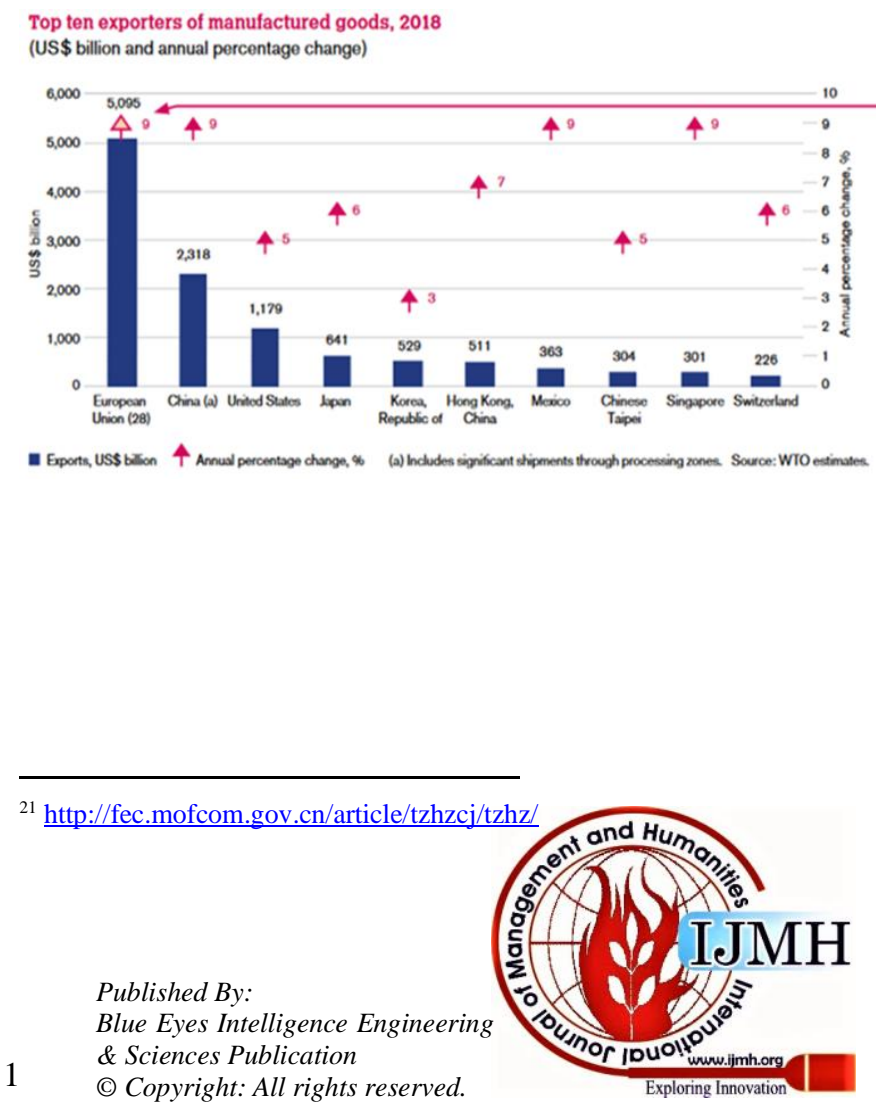
Top ten exporters of office and telecom equipment, 2018 (US $\$$ billion and annual percentage change)

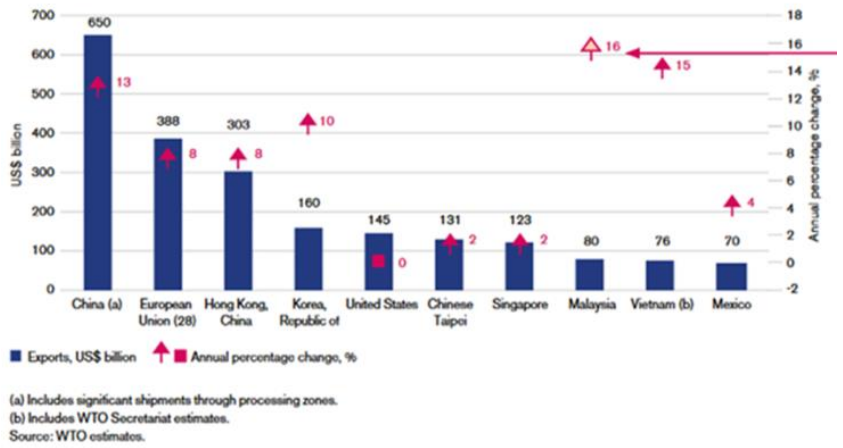

In this relationship between Mexico's deficit and surplus with China and the United States, it should also be noted that US is a competitor of China with respect to imports to the Mexican market, an example of which is found in soybeans and oil, products that both Mexico and China consume within their main imports. Therefore, it is important to highlight that the composition of trade of both China and Mexico has similarities, however, these two trading partners compete under different conditions determined by global factors, such as the United States' intervention in the trade chain, as well as by internal policies that each of their governments have adopted over the years.

\section{Opportunities}

\section{i) Tourism Exchange}

As is clear from the previous chapter, in terms of commercial services, the main industry in which Mexico is an exporting leader is tourism, besides, according to the report "Panorama of international tourism. 2019 Edition", Mexico is among the top 10 tourist destinations, ranked as the 7th largest tourism destination.

On the other hand, according to the aforementioned report, the World Trade Organization maintains that tourism grows faster than merchandise trade, making tourism an important component of export diversification for both emerging economies and for developed countries, also, tourism has a great capacity to reduce the trade deficit and to compensate the decrease in the export earnings of other goods and services.

Likewise, it should be noted that tourism is the third largest category of exports in the world, only after chemicals and fuels and ahead of the automotive and agricultural industries.

\section{Export earnings bv product categorv (USD billion)}

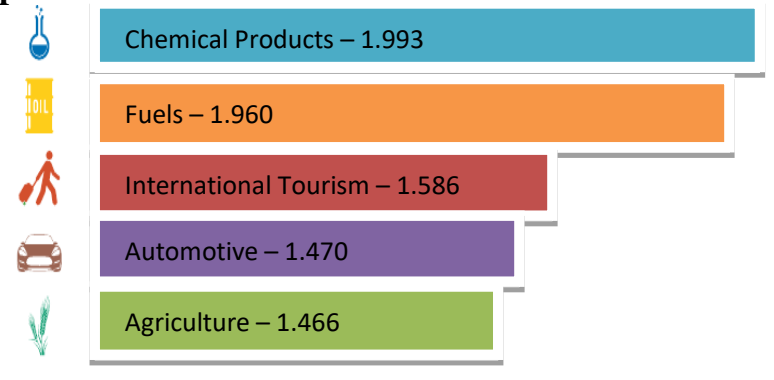

Source: World Tourism Organization

On the other hand, it is also highlighted that China continues to be the country that spends the most in tourism, even though Chinese tourist are not the ones who travel the most, but still they represent fifth of the global spending on international tourism, followed by the United States, Germany, the United Kingdom and France. In 2018, Chinese tourists spent \$277 billion, with a change in real terms of $5 \% .22$

In addition to this, around $10 \%$ of the 1,400 million inhabitants of China make international trips, and by 2027, the number of people with passports is expected to reach 300 million, equivalent to $20 \%$ of the Chinese population.

Consequently, taking into account that international tourism trends remain high, increasing steadily, subject to the fact that in 2020 and in the near future they decrease due to Covid-19, the tourism industry is a source of exports that Mexico should take advantage of and focus on the Chinese market, because even though China is already in the first place of tourists that spend the most on tourism, statistics indicate that the number of Chinese tourists will continue to increase, therefore, make of Mexico the main place Destination in Latin America for Chinese visitors must not only be maintained, but intensified.

\section{ii) Trade war between China and the United States}

While the dispute between the world's two largest economies has been a major risk factor for investors since 2018 and it has put the economic prospects of countries in the Asia Pacific region under threat, it could also bring notable gains to other countries if the conflict continues.

According to a report by the United Nations Conference on Trade and Development (UNCTAD), among the nations that are primarily presented with the opportunity to benefit from such a trade war are Europe, Mexico and Canada.

It is necessary to take into account that bilateral tariffs are not very effective in protecting national companies, but they are very valid instruments to limit trade from the affected country that is considered to be affecting the national economy of the country that imposes them. The reason is simple: bilateral tariffs alter global competitiveness and benefit companies that operate in countries that are not directly affected by them, that is why among the effects of tariffs between the United States and China is mainly to alter competitiveness between these two countries, opening the door to new global competitors, who, if prepared for this opportunity, could be representative for their international trade and economy.

This is so, since bilateral trade between the United States and China has decreased and will continue to decrease if its friction continues, and at the same time it will be replaced by trade coming from other countries. And then, it is when other nations who previously trade with US and China can make a profit out of this situation.

In fact, according to UN calculations, the \$250 billion in Chinese exports subject to US tariffs, approximately $82 \%$ has been diverted and will be diverted to companies in other countries. On the other hand, approximately $12 \%$ will be

${ }^{22}$ World Tourism Organization e-Library https://www.e-unwto.org

\section{Published By:}

Blue Eyes Intelligence Engineering

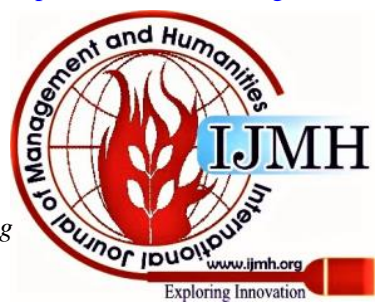




\section{Development of Trade Relations Between Mexico and China Under Non-Bilateral Trade Treaties}

retained by Chinese companies and only $6 \%$ will be in the hands of US firms.

So that is why the diversification of China's trade is also a strategy that China itself has followed, because the tariffs imposed by the United States cannot be absorbed by the companies; so, this also explains the rise in its imports to Mexico, causing a sustained increase in Mexico's trade balance, specifically in China's surplus regarding Mexico.

Similarly, the approximately US $\$ 85$ billion in exports, subject to China's tariffs, around $85 \%$ will be captured by companies from other countries. While, from that same total, US firms will only retain less than $10 \%$, while Chinese companies will capture around $5 \%$. The study carried out by the United Nations Conference on Trade and Development indicates that these results are consistent in different sectors, from machinery to furniture, communication equipment, chemical products or precision instruments.

Consequently, the countries that are expected to benefit the most from the tensions between the United States and China are those that are most competitive and have the economic capacity to replace American and Chinese companies; cases like the European Union, where exports are the ones that will increase the most, capturing around US $\$ 70,000$ million of bilateral trade between Washington and Beijing (\$50,000 million of Chinese exports to the United States and $\$ 20,000$ million of US exports to the Asian country).

Meanwhile, Mexico would be the great beneficiary from the American continent, with a profit from new exports that exceed $\$ 26,000$ million, what in the same way explain the sustained surplus that Mexico has regarding its trade with the United States, even until last year (2019). According to the most recent publication of the World Trade Organization, Mexico is the ninth largest export economy in the world and the United States and China are its first and third markets, respectively, from this that the confrontation between those two countries means, indirectly, an opportunity to Mexican exports to potentiate themselves towards these two destinations. Actually, the Mexican exports have already increased in both North American and Chinese markets, but also China's imports to Mexico are far above Mexico's exports to that country. But this behavior in the global trade is mainly because geographical proximity between Mexico and United States; nevertheless Mexico could also take advantage of this commercial friction as an opportunity to export more to China, which at the moment is not happening or not in a large scale.

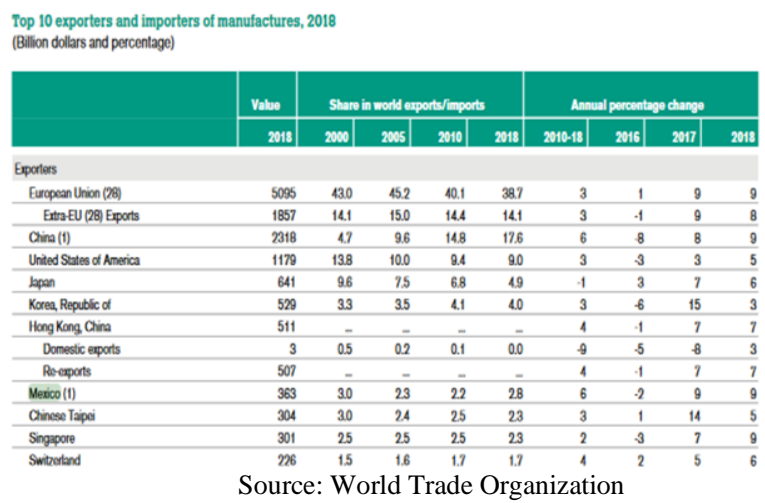

According to the United Nations Conference on Trade and Development (UNCTAD), Mexico's advantages from this trade war do not stop there: since Mexico is also the country that has had the highest income from the increase in the percentage of total exports (a 5.9\%) as a result of the conflict, well above the European bloc $(0.9 \%)$ or other major powers, such as Japan (2.3\%) or Canada (3.4\%). And although these figures do not represent a significant amount in trade world, for many countries they represent an important part of their exports.

Likewise, it should be noted that Mexico has not been the only Latin American nation that has benefited and could continue to benefit as long as this trade war continues. Argentina, Brazil, Chile and Peru have also had the opportunity to have a benefit from the distribution of exports as a result of the trade war. Nevertheless, this opportunity that the trade war between the United States and China represents for Mexico and some other countries, is not absolute because its magnitude and duration of the tariffs are not clear, the producers, in the Mexican case, have shown hesitant to make investment decisions that may be unprofitable if tariff restrictions are revoked, or simply if the two contending countries reach an agreement. Furthermore, on January 15, 2020, China and the United States signed a trade agreement; this agreement does not resolve the causes that gave rise to the trade war. The deal does not address China's subsidies to domestic industries or its firm grip on the fundamental levers of its burgeoning economy. The deal also maintains most of the tariffs the United States imposed on $\$ 360$ billion worth of Chinese merchandise, a much higher tax than what Americans pay for products from virtually anywhere else. In fact it could be many years before those issues can be resolved. The chances of a second agreement coming soon appear to be somewhat limited since the President of the United States has mentioned that maybe after his country's presidential elections, which were held in November 2020, it could be an opportune moment to conclude what both parties call "phase two" of the agreement.

The current fact is that American consumers and companies will continue to buy less merchandise from China, giving to economies like Mexico the opportunity to access its market. On the other hand, the Chinese government will continue to search for customers and suppliers in other regions to try to take advantage as much as possible of this whole situation here just analyzed.

Consequently, in recent and future years, global challenges and problems directly or indirectly affect the economies of all countries, factors such as the trade war between China and the United States, as well as the Covid-19 pandemic, represent an economic slowdown accompany by disturbances in commodity prices, financial markets and currencies, all of which will have major implications for developing countries such as Mexico and China, so taking advantage of the opportunities that the global framework offers to national economies is highly relevant .

Published By:

Blue Eyes Intelligence Engineering

Retrieval Number: J09580641020/2020@BEIESP

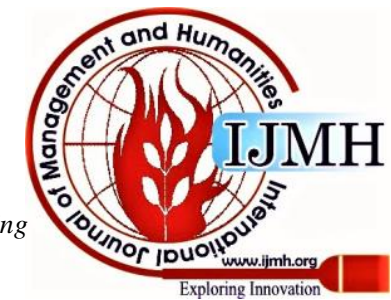




\section{Threats}

\section{i) Geographic Distance}

In this globalized world, the international connection is not a problem, what could be so called "problem" is the cost that this connections represent, as well as the time for the connection that is being sought, this, turn out to be important factors when it comes to the exchange of goods and services in commercial trade. The commercial blocks by region are reliable proof of this situation, where the main common characteristic that its participants have is its geographical proximity. Such is the case of the countries that make up the European Union and the USMCA in which the United States, Mexico and Canada participate; where Mexico maintains a surplus in its trade balance in relation to the United States. Likewise, it can be seen that China maintains a greater Foreign Direct Investment in countries that belong to the same region, in Hong Kong for example. In summary, it is logical to think that the more distant one country is from another, the less trade can be carried out between those countries, even more so if there is insufficient information on the opposite trading partner; However, the geographical distance between Mexico and China, which could be seen as a threat, is denied when analyzing the trade balance of Mexico with respect to China, where it is evident that China has reached Mexico in terms of exports, despite the geographical distance.

\section{ii) Generate products with higher added value}

One of the biggest challenges that Mexico faces in order to improve its economy and reduce the deficit with China, is the generation of products with higher added value from its own production chains, which up to now It has been an insurmountable impossibility and a commercial disadvantage, placing the country among the world leaders in the manufacturing industry, but not so, in technology or services with high added value.

Mexico has neglected the creation of transforming companies that take advantage of raw materials and that serve to manufacture final goods, which has now been a threat to different industries, making it harder for Mexican companies to innovate than to import these final goods from China. On the other hand, China, despite not growing at the rate of previous years, has increased its exports worldwide. In addition to the fact that there are products that are not produced in Mexico and that are manufactured by China.

iii) Free Trade Agreement between Mexico and China?

The possibility of signing a Free Trade Agreement (FTA) has been suggested in different business and government circles, both in Mexico and China, based on the idea that it could help reduce the deficit that Mexico accumulates in its trade balance with the Asian country. However, if it is taken into account that Mexico, unlike China, lacks an industrial policy, the deficit that is attempted to fill with the signature of an FTA, could generate an even more unfavorable situation for Mexican foreign trade.

Over the years, Mexico has signed numerous trade agreements with the intention of diversifying its trade around the world; However, according to Mexico's trade balance, in 2019 it reported a surplus of 165 billion dollars in its trade with the United States; This situation shows that Mexico continues to depend mainly on the market of a single country, the United States of North America. For this reason, the underutilization of the FTAs that it has signed is unfortunate, most of which are more used by the other trading partners than by Mexico. An example of this is the European Union, with who the deficit in the trade balance, far from being reduced, has increased after the signing of the Free Trade Agreement, Political Agreement and Cooperation (TLCUE). Another example is Israel, with whom Mexico signed an FTA so underutilized that even in 2019 trade only reached a total of \$ 950 million, with a deficit balance for Mexico of \$ 456 million. And this despite the fact that Mexico could exploit market niches in that nation, such as soft drinks, since it is a desert country in which drinks are consumed in large quantities.

In the same sense, not only there is the problem of underutilization of Free Trade Agreements, but Mexico has also concluded trade agreements that never worked as expected and were finally concluded, such is the case of the Free Trade Agreement with Bolivia, which finally was decided to conclude. In this context, an FTA between Mexico and China, rather than suggesting an opportunity or an alternative to reduce the trade deficit, for Mexico would represent a threat and also would exacerbate the problems in the Mexican trade balance if the passivity that has been the rule with other FTA keeps going.

On the other hand, it is worth mentioning, even the trade deficit that Mexico has with China is an example itself, that it is not essential to have a Free Trade Agreement to exchange goods and services, since the total trade carried out by these two countries is even greater than with countries with which Mexico has signed an FTA. In this order of ideas, it is evident that a FTA cannot be seen as an end to achieve the desired purposes, since trade agreements are a means, not an end, they are an instrument that provides tools, but that these should be used, because actually not doing so could lead to more disadvantages than advantages, such as an increase in the trade deficit.

In conclusion, even when there is no Free Trade Agreement between China and Mexico, China's commercial activity towards Mexico has been very active, to the point that in 2019, it presented a surplus in its trade balance with Mexico of $\$ 75$ billion, which once again confirms that a Free Trade Agreement is an instrument and not an end, so the existence of an FTA between these two countries is not recommended, since this could be a threat to Mexico, unless it adopts an industrialization policy, it could begin to compete with China in more equivalent terms, but as long as that does not happen and the concentration of trade with a single country is continued, it is not recommended.

\section{iv) Failure of Chinese projects in Mexico}

In the Mexican presidency from 2012 to 2018, relations between China and Mexico started with enormous momentum, however, due to the failures of two major Chinese investments projects in Mexico that occurred during the same period, the initial enthusiasm died down soon and relations remained at a very low level, which has represented a threat to Mexico, as the possibility of reducing the trade deficit it has with China and the attraction of Foreign Direct Investment have faded away, at least in the short term.

Published By:

Blue Eyes Intelligence Engineering

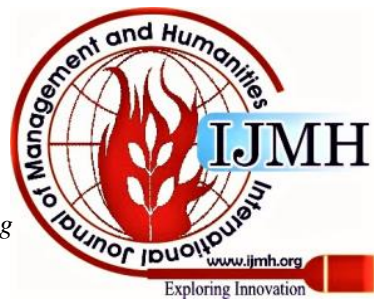




\section{Development of Trade Relations Between Mexico and China Under Non-Bilateral Trade Treaties}

The first of the referred projects was the so-called "Dragon Mart", which was described as a shopping complex displaying goods from 2,500 Chinese companies on 1,400 acres just outside Cancun. The project involved Chinamex Middle East Investment \& Trade Promotion Center Co Ltd, and 50\% Chengkai (Beijing) Investment Co Ltd from the Chinese side and the other $50 \%$ was in the hands of Mexican companies. However, since the start of its construction was announced with an investment of $\$ 180$ million investment that included 3,000 storefronts along with 722 apartments for the families of mall workers. Mexican green groups strongly criticized the Dragon Mart project because it was located amidst coastal wetlands two miles from Puerto Morelos Reef National Park and waste discharge from the project could disturb these fragile ecosystems and also pollute a key source of groundwater for the Yucatan Peninsula.

Additionally, the companies did not conduct environmental impact assessments as per Mexican law requires and lacked the required authorizations from Mexican environmental authorities. Finally, in January 2015, PROFEPA, Mexican environmental authority, canceled the project and added a further \$1.5 million fine, Dragon Mart representatives appealed such resolution issued by PROFEPA but the Mexican Collegiate Court declared the appeal as unfounded, representing the end of this fail project.

A second case was the Bullet Train Project that would go from Mexico City to Querétaro, in which through an international tender, the Mexican government opened the doors to foreign companies to participate; however, the project failed to materialize since a journalistic investigation revealed that the Chinese company that was the winner of the tender, became aware of the requirements of the tender through meetings with high-level members of the Mexican government, nine months before it was officially published, a reason that gave it an advantage over its competitors and so it was the only company that could deliver its job proposal on time. Once the journalistic investigation that made this situation public was revealed, pressure from different sectors was present and finally the tender was canceled, not to mention that the reporter in charge of such journalistic investigation faced legal demands that took several years to resolve, but she was finally acquitted.

As can be seen in both projects, these cases represented the attempt of significant projects for both Mexico and China, and although it is true that there are those who point out that the cancellation of such projects has been beneficial for Mexico; for instance, in the case of Dragon Mart, "300 thousand tons of Chinese goods would have entered Mexico per month, most at prices below the real value, putting thousands of jobs at risk"23; while in the case of the "Bullet Train" project, the avoidance of conducting projects in which personal interests were served, threatening free competition; the truth is that both projects represented investment opportunities in Mexico, which is Mexico's aim; reason why in this research it is consider that the problem were not the projects themselves but the way of carrying them out.

As a result of what happened with both the Bullet Train and Dragon Mart, it has represented a threat to projects that

\footnotetext{
${ }^{23}$ Ojeda, Marcela. Becerril Isabel, "Damage to Mexico-China relationship caused by Dragon Mart." El Financiero, January 2015.
}

could be carried out by the Mexican government with foreign companies, in this specific case, with Chinese companies, so encouraging Foreign Direct Investment from large companies requires the implementation of policies that are favorable for both Mexico and investors, not only on the Mexican side but also on the part of investors, who must be obliged to respect free competition and act in accordance with local legislation; that is, turn this threat into investment opportunities for Mexico.

\section{v) United States-Mexico-Canada Agreement (USMCA)}

A relevant aspect of the recently Agreement between Canada, United States and Mexico (USMCA), after 13 months of renegotiation, accomplished its task. The main aspect of the USMCA is the article 32.10, which requires that any USMCA member country seeking to initiate free trade negotiations with another "non-market" country must inform the other USMCA members in advance of its objectives and the potential impact of the new agreement, even if the negotiations were confidential, in order for the USMCA to become a bilateral agreement and the participation of the USMCA member seeking a new FTA with the "non-market" country will be canceled.

The USCMA adds that 30 days before the date of the signature of a trade agreement with a "non-market" country, the non-part of the new agreement have to "review the full text of the new agreement, including the annexes and collateral instruments, in order to assess the potential impact for this agreement (USMCA)". In the event that one of the parties decides to sign a pact with the "non-market" country, the other two parties would end the USMCA giving six months' notice and replace the trilateral agreement with a bilateral one. This was already agreed by Canada states, Mexico and the United States.

It is clear that article 32 of the USMCA refers to the People's Republic of China when it mentions a non-market country, that is, if one of the USMCA's members initiates FTA negotiations with China, this country will withdrawal from the USMCA. In practice, the USMCA becomes a "regional anti-China bloc", the first of its kind at the international level and consistent with the United States' geostrategic vision. But beyond the legality and constitutionality of such article, for Mexico the dilemma clearly arises regarding its relationship with China, since there is uncertainty regarding other agreements it may have with China even when these do not reach the level of an FTA; In other words, in practice, the framework for trade action between Mexico and China is reduced due to the USMCA and, as a consequence, once again, Mexico's possibilities to offset the deficit of its trade balance with China are threatened by factors of regional economic interest, more specific because of the United States' interest. On the other hand, it is true that such an article can be legally discussed; but Mexico must also be strategic regarding its commercial relationship with USA, who is the destination of $80 \%$ of Mexican imports, and with whom it has a surplus of 165 billion in 2019. ${ }^{24}$
Published By: Blue Eyes Intelligence Engineering

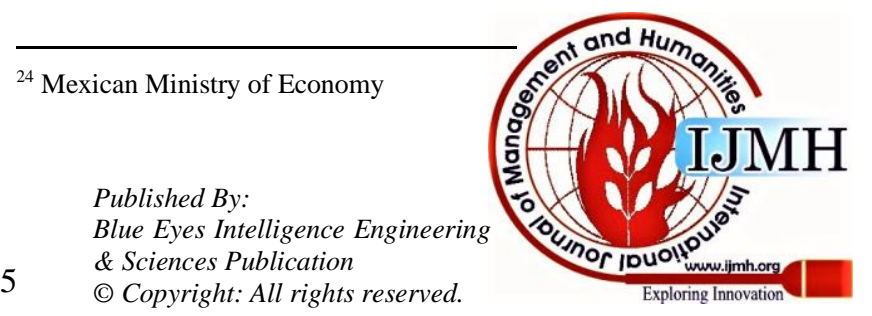


In fact, the analyst Hugh Stephens maintains that article 32.10 is a "poisonous pill" placed by the Donald Trump administration, which with this article seeks to "encircle" North America as a region where any commercial initiative with China will be prohibited. Then, in the China-Mexico trade relationship, a third actor appears on the scene, the United States of America who through article 32.10 of USMCA restricts the sovereign right of Mexico to negotiate trade agreements with States that do not have a market economy, and China is so because of its state economic intervention. So, once again the geopolitical factor limits Mexico's foreign policy. Regional power is imposed on weak states. Mexico has hardly been able to find and sustain a balance of power vis-à-vis with US. Indeed, the convergence of interests between Mexico and China continues to be influenced and determined by the United States.

\section{V.MEXICAN TRADE DEFICIT WITH CHINA}

Since there are official records (1993), Mexico has always had a trade deficit with China, that is, it buys more from China than it sells. Imports from China have grown rapidly. In 2019, the country had a record deficit of 75, almost 76, billion dollars. In 1993, the negative balance was just \$ 341.6 million. Among the main reasons of this situation is the entry of China to the World Trade Organization (WTO). Among the most important events in the field of foreign trade, it is found the reservation period between Mexico and China, since derived from the signing of the protocol of incorporation of the Asian country to the WTO in the year 2001, Mexico established a six-year reservation so that the countervailing quotas on certain imports of Chinese products did not have to be subject to the rules of the World Trade Organization (WTO); the six-year reservation ended on December 11, 2007; before the deadline was met, Mexico, through the International Trade Practices Unit (UPCI) of the Ministry of Economy, began the quota reviews, in accordance with the rules of the Foreign Trade Law and the WTO. ${ }^{25}$ Parallel to the research carried out by UPCI, a negotiation process with China began, in which the participation of UPCI together with the industries directly involved in the specific issues, determined the most sensitive fractions; However, even so, the Mexican industry was affected and overwhelmed by the Chinese products that entered Mexico once the reservation concluded, to the point that in the following immediate years, the trade deficit increased by up to 11 billion dollars26, and as consequence the Mexican industry was bankrupt and many jobs were loss. The economic exchange between Mexico and China maintained an upward trend and, at the same time, a consequent growth of the deficit for Mexico. The composition of imports from Mexico changed slightly with respect to the increase in intermediate goods. The major concern in various sectors of the country has been the trade deficit and the low added value of Mexican exports to China. What has been observed is an increase in exports of pork and tequila. But $74.5 \%$ of imports originating in China are

${ }^{25}$ Ramírez Gutiérrez, José Othón. Compensatory quotas with China: A learning case for Mexican trade. Virtual legal library of the Institute for Legal Research of the National Autonomous University of Mexico (UNAM).

${ }^{26}$ Mexican Ministry of Economy intermediate goods, and $11.2 \%$ are capital goods, many of which are used in the automotive and electronics industries to be exported, already assembled, in cars and electronic devices, to United States' market, and just a small part remains in the Mexican market.27

On the other hand, according to the Mexican Ministry of Agriculture, exports from the agricultural sector to the Asian country totaled 321 million dollars in 2017, which meant an increase of 54\%. Meanwhile, steel, textiles and shoes, faced controversies over the low prices of China's products, including protests by enterprises in Monclova and Guanajuato.

The slowdown in Chinese growth, or new normality, as they call it, implies a new challenge for the Mexican economy, in addition to the trade deficit, because the new Chinese normality and strategy implies less imports in order to promote the national market. In such a way that Mexico has to face a huge and growing trade deficit in conditions of short and medium term reduction of exports to China of primary products, essentially mining, motivated by the overcapacity that affects the Chinese heavy industry and the strategy change model of growth promoted by the Chinese government.

If we compare the figures of Chinese purchases of some Mexican products like copper, aluminum, avocado, malt beer, automatic gearboxes, etc. Between 2018 and 2019, the result is very illustrating, since Mexican products worth close to half a billion US dollars have stopped entering China. Although it is true that this figure is not as representative when compared to total trade in 2019, which was for 90 billion dollars, the truth is that it is obvious that this situation negatively impacts the overall Mexican exports, and it will cause an even faster growth of deficit, at least in the short term.

\begin{tabular}{|c|c|c|c|c|}
\hline $\begin{array}{l}\text { Tariff } \\
\text { fraction }\end{array}$ & Product & 2018 & 2019 & Difference \\
\hline 8544.42 .04 & $\begin{array}{l}\text { Copper, } \\
\text { aluminum or its } \\
\text { alloys }\end{array}$ & 7,413 & 5,540 & 1,873 \\
\hline 0804.40 .01 & Avocados & 31,793 & 19,108 & 12,685 \\
\hline 2203.00 .01 & Malt beer & 192,877 & 94,038 & 98,839 \\
\hline 8708.40 .03 & $\begin{array}{l}\text { Automatic } \\
\text { gearboxes }\end{array}$ & 319,761 & 172,718 & 15,223 \\
\hline 7403.11.01 & $\begin{array}{l}\text { Cathodes and } \\
\text { cathode sections }\end{array}$ & 357,231 & 227,825 & 129,406 \\
\hline 2301.20.01 & $\begin{array}{l}\text { Fish or crustacean } \\
\text { or other aquatic } \\
\text { invertebrate flour }\end{array}$ & 82,840 & 67,617 & 15,223 \\
\hline 7404.00 .02 & $\begin{array}{l}\text { Worn anodes; } \\
\text { waste and scrap } \\
\text { containing less } \\
\text { than } 94 \% \text { copper } \\
\text { by weight }\end{array}$ & 75,314 & 19,903 & 55,411 \\
\hline 8517.62 .02 & $\begin{array}{l}\text { Control units or } \\
\text { adapters }\end{array}$ & 53,991 & 35,624 & 18,357 \\
\hline 2710.12 .01 & $\begin{array}{l}\text { Pure mineral oils } \\
\text { from petroleum, } \\
\text { in tank car, tank } \\
\text { ship or auto-tank }\end{array}$ & 38,159 & 31,442 & 6,717 \\
\hline 8517.70.12 & Modular circuits & 35,645 & 31,319 & 4,326 \\
\hline 8517.62 .01 & $\begin{array}{lr}\text { Local } & \text { area } \\
\text { network } & \text { devices }\end{array}$ & 34,915 & 21,262 & 13,653 \\
\hline
\end{tabular}

${ }^{27}$ According to the Mexican Business Council for Foreign Trade, Investment and Technology

Published By:

Blue Eyes Intelligence Engineering \& Sciences Publication

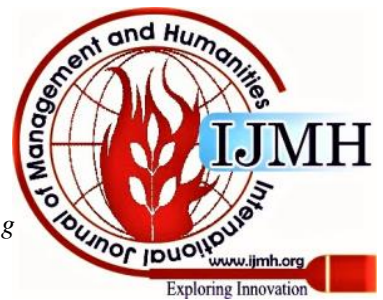




\section{Development of Trade Relations Between Mexico and China Under Non-Bilateral Trade Treaties}

\begin{tabular}{|c|c|c|c|c|}
\hline & "LAN" & & & \\
\hline 8708.93.04 & $\begin{array}{l}\text { Complete } \\
\text { clutches }\end{array}$ & 32,732 & 26,612 & 6,120 \\
\hline 8473.30 .02 & Modular circuits & 31,706 & 23,009 & 8,697 \\
\hline 8471.70 .01 & Memory drives & 26,381 & 9,931 & 16,450 \\
\hline 8471.50 .01 & Process units & 23,817 & 7,002 & 16,815 \\
\hline 8708.50 .04 & $\begin{array}{l}\text { Rear differential } \\
\text { axles without } \\
\begin{array}{l}\text { coupling to the } \\
\text { masses }\end{array}\end{array}$ & 23,659 & 1,853 & 21,806 \\
\hline 8903.92.01 & $\begin{array}{l}\text { Motor boats, } \\
\text { except those with } \\
\text { outboard motors }\end{array}$ & 19,644 & 17,019 & 2,625 \\
\hline 8537.10.04 & $\begin{array}{l}\text { Control or } \\
\text { distribution } \\
\text { panels, operated } \\
\text { by buttons }\end{array}$ & 19,443 & 9,277 & 10,166 \\
\hline 8703.23.01 & $\begin{array}{l}\text { With a cylinder } \\
\text { capacity greater } \\
\text { than } 1,500 \text { cm3 } \\
\text { but less than or } \\
\text { equal to } 3,000 \\
\text { cm3 }\end{array}$ & 425,260 & 407,767 & 17,493 \\
\hline
\end{tabular}

In the last three years, considerable progress has been made in negotiating access for new Mexican products to the Chinese market, especially agricultural products, ranging from strawberries to tequila, including pork and white corn. Mexico has been working to introduce new products: dairy products, bananas, etcetera; however, the activation of Mexican companies is urgent, along with long-term policies on foreign trade, to speed up and unlock the process of trade deficit with China, since, as has been pointed out throughout this research, and as shown in the following table, the deficit with China has and continues to maintain an increase.

\begin{tabular}{|c|c|c|c|c|}
\hline \multicolumn{5}{|c|}{ Trade Balance of Mexico with China (in thousands US\$) } \\
\hline Year & Exports & Imports & Total Trade & Balance \\
\hline 1993 & 44,777 & 386,442 & 431,219 & $-341,665$ \\
\hline 1994 & 42,162 & 499,655 & 541,817 & $-457,493$ \\
\hline 1995 & 37,002 & 520,580 & 557,582 & $-483,578$ \\
\hline 1996 & 38,277 & 759,704 & 797,981 & $-721,427$ \\
\hline 1997 & 45,882 & $1,247,376$ & $1,293,258$ & $-1,201,494$ \\
\hline 1998 & 105,977 & $1,616,494$ & $1,722,471$ & $-1,510,517$ \\
\hline 1999 & 126,338 & $1,921,057$ & $2,047,395$ & $-1,794,719$ \\
\hline 2000 & 203,586 & $2,879,620$ & $3,083,206$ & $-2,676,034$ \\
\hline 2001 & 281,774 & $4,027,253$ & $4,309,027$ & $-3,745,479$ \\
\hline 2002 & 653,913 & $6,274,381$ & $6,928,294$ & $-5,620,468$ \\
\hline 2003 & 974,369 & $9,400,591$ & $10,374,960$ & $-8,426,222$ \\
\hline 2004 & 986,304 & $14,373,843$ & $15,360,147$ & $-13,387,539$ \\
\hline 2005 & $1,135,544$ & $17,696,338$ & $18,831,882$ & $-16,560,794$ \\
\hline 2006 & $1,688,107$ & $24,438,279$ & $26,126,386$ & $-22,750,172$ \\
\hline 2007 & $1,895,338$ & $29,743,656$ & $31,638,994$ & $-27,848,318$ \\
\hline 2008 & $2,044,750$ & $34,690,310$ & $36,735,060$ & $-32,645,560$ \\
\hline 2009 & $2,207,788$ & $32,528,967$ & $34,736,755$ & $-30,321,179$ \\
\hline 2010 & $4,182,842$ & $45,607,551$ & $49,790,393$ & $-41,424,709$ \\
\hline 2011 & $5,964,225$ & $52,248,003$ & $58,212,228$ & $-46,283,778$ \\
\hline 2012 & $5,720,732$ & $56,936,129$ & $62,656,861$ & $-51,215,397$ \\
\hline 2013 & $6,468,508$ & $61,321,376$ & $67,789,884$ & $-54,852,868$ \\
\hline 2014 & $5,964,143$ & $66,257,292$ & $72,221,435$ & $-60,293,149$ \\
\hline 2015 & $4,873,152$ & $69,988,130$ & $74,861,282$ & $-65,114,978$ \\
\hline 2016 & $5,411,256$ & $69,521,795$ & $74,933,051$ & $-64,110,539$ \\
\hline 2017 & $6,712,580$ & $74,150,446$ & $80,863,026$ & $-67,437,866$ \\
\hline 2018 & $7,428,917$ & $83,510,571$ & $90,939,488$ & $-76,081,654$ \\
\hline 2019 & $7,130,476$ & $83,052,518$ & $90,182,994$ & $-75,922,042$ \\
\hline $2020 / 1$ & 485,625 & $6,939,902$ & $7,425,527$ & $-6,454,277$ \\
\hline
\end{tabular}

Likewise, the immediate logical question is why the trade deficit with China is a problem for Mexico? It is true that, according to economic theory, the fact that a deficit is good or bad depends on the factors that originate it. But economic theory also tells us what to look for know whether the deficit is beneficial or a problem. If it reflects excess import compared to export, the current account deficit may be an indication of competitiveness problems. But since it also implies excess investment compared to savings, it may well reflect a very productive growing economy. If the deficit is due to a shortage of savings and not to an abundance of investments, it may be the consequence of irresponsible fiscal policy or excess consumption. But it can also be an indicator of perfectly adequate inter-temporal trade, attributable to a temporary shock or demographic change. In other words, although it is true that the trade deficit is not necessarily bad or a problem itself, since in many cases it is a sign that the economy is doing well because consumers and companies have more money to spend; when looking at what caused the deficit in the case of Mexico, it is observed: A) Loss of Competitiveness. According to the Global Competitiveness Report 2019, issued by The World Economic Forum ${ }^{28}$, which takes onto consideration 12 pillars: Institutions; Infrastructure; ICT adoption; Macroeconomic stability; Health; Skills; Product market; Labor market; Financial system; Market size; Business dynamism; and Innovation capability in a scale from 0 to 100 of 141 countries; Mexico is ranked as the second most competitive country in Latin America ${ }^{29}$ in the position 48th. Nevertheless, in the last year it decreased two points while in 1999, it was ranked in the position 31st. This position implies a significant lag of competitiveness in comparison with other countries such as China, which in 2019 was ranked as the number 28th. In other words, Mexico productivity-enhancing investments such as new infrastructure, R\&D and skills development in the current and future workforce have been suboptimal.

Therefore, even though Mexico and China are emerging economies with growing innovation capacity, Mexico has lost standards of competitiveness while China has increased so. As consequence, the commercial deficit that Mexico has in its trade balance with China, partly, is because of its lower level of competitiveness which is direct linked with its market size and innovation capability.

B) Excess consumption of imports. Mexico is an important client in Latin America for China, not only for the quantity of merchandise it sells to it and which maintains it with a trade surplus with respect to Mexico; but also because of Mexico's geopolitical location in North America. As has been mentioned repeatedly, since 1993, there is a trade deficit with China that in 2019 reached 75 billion dollars; however, this amount has been a consequence of the flood of Chinese products in Mexico and not of foreign investment by that country. This is evident in the latest Report on Development of China's outward Investment 2018, in which Mexico appears as one of the countries that received less foreign investment from China.

Consequently, the foregoing translates into greater imports from China, a lower share of the Mexican market for the domestic industry and less diversification of Mexican imports, as well as low foreign investment from China, which does not help the national market to have a better industrial development due to the lack of capitals to develop or invest in new technology or national industrial chains.

C) Lack of savings. In this regard, the International Monetary Fund (IMF) has calculated that in 2018, gross savings in Mexico represented 21.2\% of Gross Domestic

\footnotetext{
${ }^{28} \mathrm{http}: / /$ www3.weforum.org/docs/WEF_TheGlobalCompetitivenessReport2 019.pdf
}

${ }^{29}$ After Chile, which was ranked in the place $33^{\text {rd }}$

Published By:

Blue Eyes Intelligence Engineering

\& Sciences Publication

DOI:10.35940/ijmh.J0958.0641020

Journal Website: www.ijmh.org

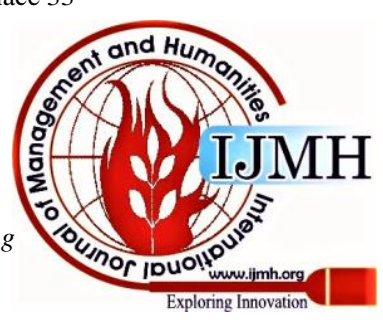


Product (GDP), which decreased to 20.5\% in 2019, which will continue to fall until reaching $17.5 \%$ in 2024 , which if updated, would be the lowest level since the 1994 crisis. This is the total income that the government, companies, and families spend on savings, reflecting the money that goes toward achieving goals for short, medium and long terms. Since the international crisis of 2008-2009, savings have decreased in Mexico, the majority of which are resources from companies or individuals. In addition to this, in 2019 the Gross Domestic Product (GDP) of Mexico fell 0.1\% according to data from the Mexican National Institute of Statistics and Geography of Mexico (INEGI). This is the first time in ten years that the growth of Latin America's second largest economy is negative, something that had not happened since 2009 when Mexico recovered from the global economic crisis.

In conclusion, because of the reasons here analyzed, it must be a priority for Mexico to implement economic and fiscal policies that help it diversify both its imports and its exports, as well as promote investment, in order to reduce the trade deficit it has with China, since not doing so, this will become more acute each time, especially considering the new policy and the slowdown of Chinese economy, giving preference to its national market, and reducing its imports.

\section{VI.DESPUTE FOR THE AMERICAN MARKET}

A situation of other concern is the displacement of Mexico by China in the US market, despite the fact that the first has signed the USMCA and China has not. This leads us to recognize that the most important thing, for both Mexico and China, is not the bilateral relationship, but the presence in the United States market. Yet each of these nations has strengths in its ties to that country.

Over the years, China and Mexico have competed for the American market. In recent years, both have maintained a surplus in their trade balances with respect to the United States; However, according to the list of the Top Trading Partners - February 2020 that the United States Census Bureau published on its official website, Mexico appears as the main trading partner of that country in both imports and exports, representing a total of $15.4 \%$ of total US trade; while China is its third trading partner, accounting $11 \%$ of its trade.

\begin{tabular}{|c|c|c|c|c|c|}
\hline \multicolumn{6}{|c|}{ Top Trading Partners - February 2020 Year-to-Date Total } \\
Trade
\end{tabular}

Source: United States Census Bureau

Statistics published by the United States indicate that in the first two months of this year, Mexico returned to occupy the first place as supplier to that country, a place that it lost in 2003 to be occupied by China, but that in the first months of this year Mexico has recovered. As a consequence of the USCMA, it is evident that Canada and Mexico equally complete strongly for the North American market; however, China does not have a Free Trade Agreement that grants trade benefits, as it is the case for Mexico and Canada, which reflects the strong competition that China represents not only for Mexico but also for Canada. Thus, in 2002
Mexico exported 134,616 million dollars to the United States; while in the same year, China exported \$125,192 million to the same destination; however, in 2003 Mexico made exports for \$138,060 million; while China exported 152,436 million dollars, taking the place of Mexico as the main supplier of the United States of America; However, in terms of competition in the North American market, Mexico once again took the lead when, in the first half of 2020, it had more exports to the United States than China, 57,389 and \$56,093 million, respectively, as shown in the following table.

\section{USA imports from China and Mexico from 2000 to 2020}

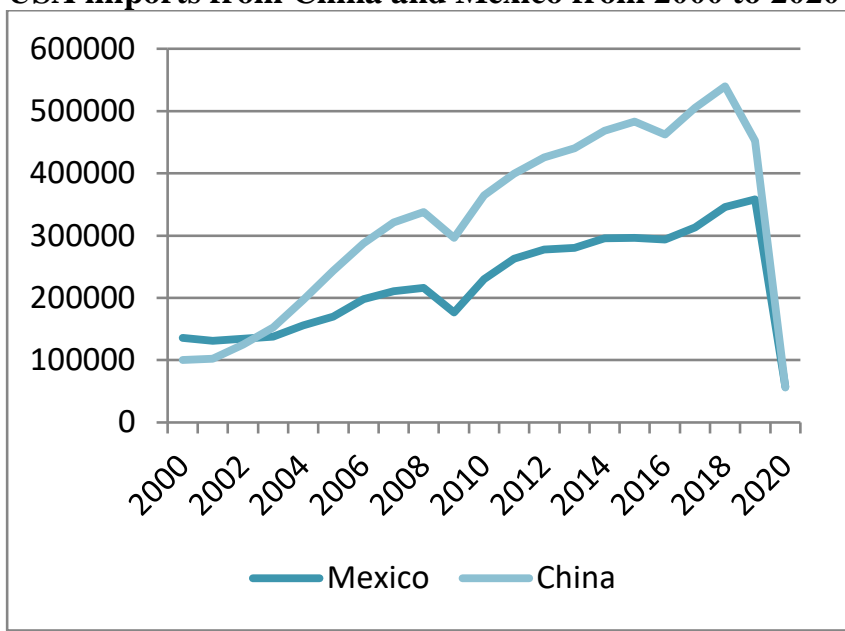

Source: Elaborated with data from the United States Census Bureau

The main products that Mexico exports to the United States are goods for the assembly or manufacture of aircraft or aero-parts, road tractors for semi-trailers, airbags for safety devices, disc brake mechanisms or their component parts, memory units, boxes of automatic speeds, copper, aluminum and its alloys, fiber optic cables, avocado, strawberries, raspberries, blackberries, blackberries and blackberriesraspberries, cucumbers and gherkins, fresh or refrigerated, tequila $^{30}$, among others; while China imports to US electronic equipment, power generation equipment, toys, clothing, furniture, iron and steel, footwear, plastic ${ }^{31}$, among others. From this list of products that both Mexico and China import into the United States, there is direct competition in electronic devices and power generators; however, there are also industries in which they are not necessarily direct competitors, such as the agricultural industry from which Mexico imports and China does not and footwear that China imports and Mexico does not.

\begin{tabular}{|l|l|}
\hline \multicolumn{3}{|c|}{ Trade with United States in 2018 } \\
\hline \multicolumn{3}{|c|}{ Mexico } & \multicolumn{1}{|c|}{ China $^{|c|}$ Imports } \\
\hline \multicolumn{3}{|c|}{$\begin{array}{l}\text { Mexico was the United } \\
\begin{array}{l}\text { States' 2nd largest supplier } \\
\text { of goods imports }\end{array}\end{array}$} & $\begin{array}{l}\text { China was the United States' } \\
\text { largest supplier of goods } \\
\text { imports }\end{array}$ \\
\hline U.S. goods imports from & U.S. goods imports from \\
\hline
\end{tabular}

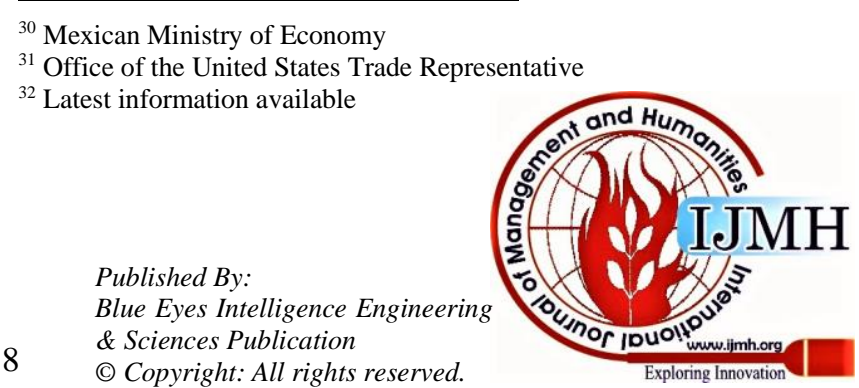




\section{Mexico totaled $\$ 346.1$ billion. U.S. imports from Mexico account for $\mathbf{1 3 . 6 \%}$ of overall U.S. imports.}

The top import categories were: vehicles ( $\$ 93$ billion), electrical machinery (\$64 billion), machinery (\$63 billion), mineral fuels (\$16 billion), and optical and medical instruments (\$15 billion).

U.S. total imports of agricultural products from Mexico totaled \$26 billion in 2018, U.S. largest supplier of agricultural imports. Leading categories include: fresh vegetables (\$5.9 billion), other fresh fruit (\$5.8 billion), wine and beer (\$3.6 billion), snack foods (\$2.2 billion), and processed fruit \& vegetables ( $\$ 1.7$ billion).

U.S. imports of services from Mexico were an estimated \$25.8 billion. Leading services imports from Mexico to the U.S. were in the travel, transport, and technical and other services sectors.

\section{Investment}

\begin{tabular}{ll|lll|} 
U.S. foreign direct & U.S. foreign direct
\end{tabular}
investment (FDI) in Mexico investment (FDI) in China (stock) was $\mathbf{\$ 1 1 4 . 9}$ billion. (stock) was $\mathbf{\$ 1 0 7 . 6}$ billion. U.S. direct investment in U.S. direct investment in Mexico is led by China is led by manufacturing, nonbank manufacturing, wholesale holding companies, and trade, and finance and finance and insurance. $\quad$ insurance. Source: Office of the United States Trade Representative

As can be seen from the table immediately above, there is great competition from exports that both Mexico and China make to the United States. In 2018 in US imports of products, Mexico was its second supplier, while China was the first, so Mexico's exports accounted $13.6 \%$ of United States total imports, while those from China occupied 21.2\%; highlighting special competition in electrical machinery products.

On the other hand, regarding US agricultural imports, Mexico is the main supplier to the United States, while China is the third; in this area, the competition between China and Mexico for the US market is in fresh vegetables, fruit, snack foods, and processed fruit and vegetables.

Regarding the export of services from China and Mexico to the United States, there is also strong competition, as both countries provide the North American country with transportation and travel services; however, the amount of exports from Mexico are larger than those from China to the same destination.
In terms of Foreign Direct Investment (FDI), in the same way China and Mexico compete to attract the largest amount of it from the United States, since this represents economic growth for the respective economies, but the industries competing the most are manufacturing, finance and insurance. According to statistics from the Office of the United States Trade Representative, in 2018 Mexico received $\$ 7$ billion more than China.

Overall, in 2018 China overtook Mexico as the main supplier of products to the United States; however, in the first two months of 2020, Mexico has once again taken the lead over China. But agriculture and services competition has favored Mexico more than China. The same happens regarding IDF, where they compete to attract investment from the U.S., an area in which Mexico has shown greater potential to attract the US investments than China.

Regarding the relations that China and Mexico have with the North American country, both Washington and Beijing have a seat as a permanent member of the United Nations Security Council. Likewise, China has managed to forge increasing relations of economic interdependence with the United States, which would make a confrontation very expensive. No less important is that the prevailing discrepancies, for example regarding the situation in Taiwan, are offset by the coincidences on issues more crucial to American national security, such as the fight against terrorism.33

But Mexico also has certain advantages in the relationship with Washington. Geographical proximity is an inescapable factor, not only because of the trade potential, but because it confirms that US security passes through the security of Mexico. There are important ties of economic interdependence between the two nations, in addition to an extremely complex bilateral agenda that covers very diverse topics: border security, drug trafficking, migration, environmental deterioration, bilateral political agreement and with respect to third parties (for example, with respect to Latin American nations such as Cuba, Venezuela and the Central American countries)34. Likewise, Mexico is part of the USMCA, which constitutes an institutional framework for a very intense relationship. As if that were not enough, the Mexican diaspora constitutes a population in permanent growth in the United States.

When NAFTA (today USMCA) entered into force in January 1994, Mexican exports to the US grew steadily. The expectation was that the treaty, together with the geographical proximity and the influx of foreign investments, would place Mexico in an advantageous position with respect to any other country when it comes to contesting for the US market (with the exception of Canada). However, China's rise in the 1990s, its entry into the WTO in 2001 and its transformation into the main destination for

${ }^{33}$ Haro Navejas, Francisco: «China in North America: the relationship with Mexico and the United States» in Nueva Sociedad No. 203, 5-6 / 2006, pp. 170 .

${ }^{34}$ During the inauguration of Felipe Calderón as President of Mexico in December 2006, the US government, in the voice of George H.W. Bush and the ambassador of that country, Antonio Garza, asked the Mexican government for their "mediation" between the United States and Cuba, in the face of the disease that afflicts Fidel Castro. Angélica Mercado: «The United States asks Mexico to mediate with Cuba» in Milenio, 12/2/2007, pp. 4-7.

Published By: Blue Eyes Intelligence Engineering \& Sciences Publication

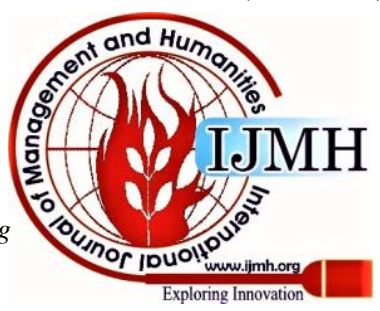


foreign investment contributed to displacing Mexico from that privileged situation. In 2000, when the Mexican presence in the US market was at its best, some of the problems stemming from the Chinese success were already in sight. For example, those related to the increase in production costs in Mexico vis à vis China and the decline of the US industrial base in the national territory, which moved to China.

These events are estimated to have contributed decisively to the loss of $80 \%$ of jobs in Mexican maquiladoras.35 In fact, numerous investments that used to flow to Mexico moved to China. Thus, between August 2002 and January 2003, China displaced Mexico as the second largest exporter to the United States. It would not be until the first quarter of 2010 and the first two months of 2020, when Mexico would regain the second and first position among the US trading partners, respectively, relegating China to third and second place, although this could change, part of the problem is that the products that Mexico exports to the US are similar to the Chinese. So, the proposal is that Mexico stops continuing to bet on the maquiladoras as sustenance for its export offer and develop products with higher added value. An equally important aspect is to take advantage of the tariff advantages provided by the USCMA.

\section{VII.CONCLUSIONS}

\section{A. Global factors beyond Mexico and China}

Even though the growth of the Chinese economy has slowed in recent years, it is still emerging as a one of the biggest economies. If the Chinese dream were to come true, China would be the first poor country, with a largely rural population, to achieve being the largest economy in the world. The process will take a long time, but in its favor, China has a national project that is not threatened by any political counterparts, on the other hand, Chinese culture has shown to be patient and recognizes that, in the end, they will achieve what they set out to do, unless external circumstances happen.

At the international level, the most important thing for China is to ensure access to the natural resources to fuel its vertiginous economic development, but on the other hand, it must guarantee its access to the markets and capitals of the planet. Thus, to a large extent, its prosperity also depends on the course of global events.

In the elapsed years of the 21st century, the relationship between Mexico and the People's Republic of China has been shaped by the changes that have occurred in the respective economies of the two countries; in their economic policies and in the corresponding visions that each leadership has on the position that their country aspires to occupy in the world. In other words, the bilateral SinoMexican relationship has been determined by the internal economic situation of each party and the ups and downs of the international economy, as well as by the strategies that the governments of Mexico and China have followed during the last twenty years in relative to their mutual economic growth and their respective geopolitical accommodations in the world.

\section{B. China-Mexico's relationship, opportunity or threaten?}

\footnotetext{
${ }^{35}$ McHardy Reid David, Alethia Jiménez y Peter Rahmer: «nafta, Mexico and the China Factor» en Voices of Mexico N ${ }^{\circ} 76,7-9 / 2006$, p. 77.
}

Regarding relations between Mexico and China, in Mexico the perception still prevails, especially among some entrepreneurs, of a "Chinese threat". Part of this perception is related to the national economic problems derived from the fast commercial opening of China and the impossibility, especially of the small and medium-sized Mexican companies, of adjusting to the new conditions of international competition. It is also true that, unlike Chinese, the Mexican State is weak. But it is equally true, and history and experience have demonstrated that China does not always act in accordance with international trade rules, and in fact Mexico has had to defense through the World Trade Organization system due to unfair practices from China. Unfortunately, some Mexican entrepreneurs and government authorities have blamed China for its internal problems that still need to be solved, without realizing that regardless of the actions China, which only makes the problems that already exist internally more visible, Mexico has to do his own work.

In conclusion, as it has been shown throughout this research, that there are areas of opportunity that have not been explored yet or not, enough, or do not have institutional support from the Mexican government; opportunities such as the tourism industry, the sports sector, specifically dealing with soccer, industrial production chains, and technology transfer are opportunities, and should be areas in which Mexico must work to at least reactivate its economy in the field foreign trade. It is true, the economic model with China presents areas of great competition, for instance in electrical machinery and agriculture; but even so, there are areas of opportunity within the same sectors, such is the case of soybeans that, as a result of the trade war that China has maintained with the United States, America has stopped exporting to China, and now Brazil is taking place as China's supplier in that sector. The aforementioned shows that it is necessary to be prepared for productions in order not only to take advantage of opportunities like these, but also to diversify markets, even not only towards China or the United States, but also towards the rest of the world, taking advantage of the FTAs that Mexico has signed with more than 50 countries.

In the global world that we live in today, and in which foreign trade is a very important part of all the economies of the world; it is not enough to adopt a position of being an open economy; it is also essential to use all the tools that have been created in order to have a greater international presence in terms of trade as exporters and not only as importers, which will translate into economic growth.

\section{Trade relationship between the US, Mexico and China}

The US intervention in Mexico's relationship with China is evident, and it is clearly seen in Article 32 of the USMCA, preventing these two trading partners from having a Free Trade Agreement; a situation that further exacerbates Mexico's attempt to reduce its trade deficit with China;

However, it is exactly for this reason that the study of more proposals should be valued, focused and implemented, because regardless of whether the content of the mentioned article is contrary to Mexico's sovereignty,
Published By: Blue Eyes Intelligence Engineering \& Sciences Publication (C) Copyright: All rights reserved.

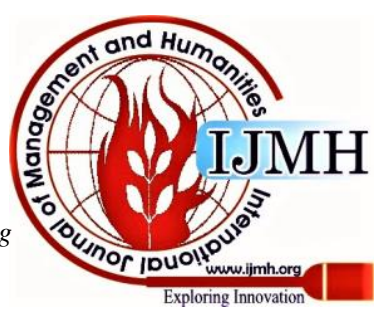




\section{Development of Trade Relations Between Mexico and China Under Non-Bilateral Trade Treaties}

the truth is that in practice Mexico must propose viable strategies in order to keep their economic and commercial interests safe, both with its main trade partner and with China, which is its second supplier and third destination for its exports; while Mexico for China is the second most important trading partner in Latin America and is the main trading partner of the US.

Consequently, and apart from what is stipulated in Article 32 of the USCMA, it is not considered opportune to try to negotiate a Free Trade Agreement with China, first, due to the lack of industrial policy that Mexico has, at least at this moment; secondly, because the national policy followed by the current president of Mexico has shown no interest in improving relations with China and thereby reducing the trade deficit or attracting quality Chinese FDI to Mexico, so, as long as that does not change, and If Mexican entrepreneurs maintain a preference for the US market, the signing of an FTA with China would be a huge opportunity for China to multiply its exports to Mexico and so the Mexican trade deficit, which is already a disadvantage for Mexico.

Likewise, it should not be overlooked that both Andrés Manuel López Obrador and Donald Trump have something in common: they want to reduce the trade deficits of their respective countries with China, the second largest economy. In the case of Mexico, the negative balance with China is at its highest level for the last 27 years; that is, since it has been registered by the Ministry of Economy of Mexico.

China-Mexico relations stand to benefit both countries regardless of which direction US trade policy turns. If the US scales back trade with Mexico, Chinese trade will fill the gap as Chinese firms gain access to countries around the world via Mexico's trade deals and cost-efficient labor base. If US policy continues to favor trade with Mexico, Chinese firms stand to gain far more access to US markets through a Mexican alliance.

\section{Mexico's trade balance deficit with China}

The China and Mexico trade scheme not only has several areas in which they converge and makes them clearly competitors, but they also have areas of opportunity, such as tourism, agriculture and sports talent; areas that must be explored if what is desired is to reduce the trade deficit that has been discussed. At the same time, the attraction of foreign investment, with high quality and that transfer technology, must be a priority not only for government policies but also for entrepreneurs who trade with the Asian country.

In this research it is considered that ending or reversing the trade deficit that Mexico has with China is a really challenge for Mexico, at least in the short term, due to since 1993 it has only been growing year by year, but at the same time what is considered viable in the short term, is to slow down the speed rate at which it grows, so the proposal is not to stop or avoiding trade with China because actually that could not be possible for Mexico and would not be beneficial for the Mexican economy, but importing more to that country. In this sense, even the former Chinese ambassador to Mexico, Qiu Xiaoqi has mentioned that "All success is reserved for those companies that are not afraid of China and its market. Entrepreneurs and merchants must visit more China, read about China and speak Chinese," and a good example of this are Grupo Bimbo and Maseca, the
Mexican giants that have managed to conquer the Chinese market.

\section{E. Bilateral agenda}

China, in addition to being an engine of the world economy, for Mexico it represents a partner that cannot be overlooked due to the high amount of bilateral trade those countries carry out, which in 2019 it accounted $\$ 90$ billon. The effective knowledge and definition of a daily agenda with the second trading partner undeniable have decreased significantly in the last five years, despite the increasing presence of China in Mexico.

The Chinese discontent over the Bullet Train project that would run between Mexico City and Querétaro, as well as the cancellation of the Dragon Mart project, among others, seem to completely derail bilateral efforts, a situation that must be addressed by specialized counterparts immediately. At the moment in Mexico there is no "responsible" institution that is in charge of this complex bilateral relationship; as well as there is no institution in charge of promoting trade with China, which throughout the last three administrations has been left to presidential discretion, and as consequence the interest in the relationship with China has been very different, actually during this administration with López Obrador is been almost null.

\section{F. Mexico's internal problems}

Economic development is not a pre-determined destiny. Proactive efforts are needed to start and sustain the development process. Making technology and innovation part of an economy's DNA is challenging in itself but Mexico must also account for enabling this change through human capital investments and mitigating the unintended adverse impacts of technological advancements on income distribution and social cohesion. Mexico must improve talent adaptability; that is, enable the ability of their workforces to contribute to the creative destruction process and cope with its disruptions. Talent adaptability also requires a well-functioning labor market that protects workers rather than jobs. As monetary policies begin to run out of steam, it is crucial for Mexico to rely on fiscal policy, structural reforms and public incentives to allocate more resources towards the full range of factors of productivity to fully leverage the new opportunities provided by the Fourth Industrial Revolution.

In recent decades growth has failed to reach the levels that can substantially reduce poverty and inequality in Mexico and the international trade with China could be a tool to mitigate this situation.

As you are well aware, corruption and crime have played an important role limiting growth, and addressing these issues is an important policy priority for Mexico, otherwise it is hard to visualize a sustainable economic growth. Other constraints on growth include labor market informality, limited competition in some sectors, and inadequate access to financial and telecommunication services.

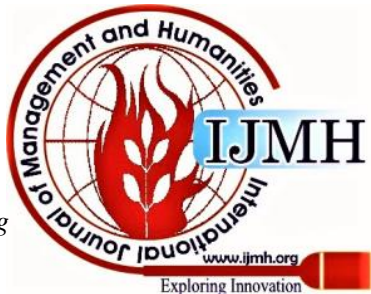




\section{REFERENCES}

1. 安宝均, 闯入墨西哥市场.经贸世界,2002

2. Arriaga N., Rosalinda. José Luis Estrada López. Reconstrucción del Económico. México. 2002.

3. Bustelo, P. y Fernández Lommen. La economía china hacia el siglo XXI. Veinte años de reforma, Edit. Síntesis, Madrid. 1996

4. Chacholiades Melquiades. Economía Internacional. Edit. Mac GrawHill. México. 1980.

5. 陈建, 史修松. 中国、墨西哥对美纺织品贸易比较-兼论中国对墨 西哥的市场挤出.世界经济研究,2006

6. 程杲.墨西哥反倾销特点及对华政策研究.世界经济情况,2006

7. Cornejo Garza, José Efrén. Ambiente de negocios Internacionales. Cursos en Línea. Unidad 3. La Intervención Gubernamental y el Comercio. Capítulo 5. Teorías del Comercio Internacional. Universidad de Monterrey. 2018.

8. Cornejo, Romer: Mexico and China's competitiveness, China and Latin America, New approaches to cooperation and development, A second Silk Road? Intal, Buenos Aires, 2005

9. Cristina Rosas, María. Encuentros y desencuentros: las relaciones entre México y la República Popular China. Edit. Nueva Sociedad. México. Julio-Agosto 2010.

10. 戴翔. 墨西哥对华反倾销问题研究.温州大学学报,2006

11. Dainzú Patiño. ¿Cómo reducir el déficit comercial de México con China? Expansión. México. Agosto 2018.

12. De Icaza González, Carlos. México y China: Una asociación estratégica cada vez más exitosa. Excelsior. México. Diciembre 2016.

13. De la Mora, Luz María. Towards a new commercial version between Mexico and China. Ministry of Economy. Mexico. January 2019.

14. 杜莉,谢皓.中国与墨西哥高技术产品在美国市场的竞争状况分析基于出口形似度指数与转移份额分析方法。中国软科学, 2011

15. Dussel Peters, Enrique. Mexican Firms Investing in China 2000-2011. Inter-American Development Bank. December 2012.

16. Dussel Peters, Enrique. La relación México China. Desempeño y Propuestas para 2016-2018. Unión de Universidades de América Latina y el Caribe. México. 2016.

17. Eaton, Jonathan and Samuel Kortum. Technology, Geography, and Trade. Econometrica. 70(5): 1741-1779 (September). 2002.

18. Estevadeordal, Antoni. Theodore Kahn. Los caminos a China: la experiencia de las empresas latinoamericanas en el mercado chino. Banco Interamericano de Desarrollo. China. Octubre 2012.

19. Fernández Lommen. La economía china en el siglo XXI. Boletín Económico de ICE, 2676, 31-38. 2000

20. Fierro, Tonatiuh. Acerca del primer viaje oficial del canciller Ebrard a China. Nexos. México. Septiembre 2019.

21. Ge, W. Special Economic Zones and the Opening of the Chinese Economy: Some Lessons for Economic Liberation. World Development, 27(7), 1267-1285. 1999

22. González García, Juan. Mendoza Cota, J. Eduardo, Juanjuan Zhang. The Impact of China on Mexico-USA Relations: Economic Evolution and Strategic Posibilities. Análisis Económico Num. 75, vol XXX. México. 2015

23. 顾莉萍, 刘合光,丁开勇.中国-墨西哥农产品贸易特征与前景展望. 湖北经济学院学报,2007

24. 郭德琳.中墨经贸关系的机遇与挑战.国际经济合作,2011

25. Haro Navajas, Francisco. China in North America: the relationship with Mexico and the United States. Nueva Sociedad No 203, 5-6/2006. USA. 2006.

26. Harrigan, James. Haiyan, Deng. China's Local Comparative Advantage. NBER Working Papers 13963. National Bureau of Economic Research, Inc. Virginia, USA. 2008

27. Harrigan, James. Airplanes and comparative advantage. NBER Working Paper 11688. Massachusetts. 2006.

28. 胡加齐.对美出口墨中非“对手”. 瞭望新闻周刊,2006

29. 贾利军.中国与拉美主要国家贸易互补性实证分析.世界经济究, 2005

30. 加里.杰里菲.中国与墨西哥发展模式比较.国外理论动态,2006

31. Jimenez, Felix. Lahura Erik. La Nueva Teoría del Comercio Internacional. Pontificia Universidad Católica del Perú. Lima, Perú. 2017.

32. Krugman, Paul. Economía Internacional, Teoría y Política. Pearson Education Limited Edit. 11th edit. Harlow, United Kingdom. 2018.

33. Landefeld, J. Steven and Robert P. Parker. Preview of the Comprehensive Revision of the National Income and Product Accounts: BEA's New Featured Measures of Output and Prices in BEA Survey of current business Julio de 1995. Comercio Exterior en México durante los Noventa. Revista Análisis

34. 李双燕,赵文武.中墨服装在美国市场上的竞争力分析.河南工程学 院学报 (自然科版) ,2011

35. 李璐.墨西哥贸易壁垒的应对策略[J].进出口经理人,2008

36. 梁建波.墨西哥-中国在国际贸易领域的有力竞争者.中国国情国 力,2003

37. 罗云.中国与墨西哥贸易竞争性与互补性研究.对外经济贸易大学 硕士研究生学位论文,2010

38. 刘秀玲. 国际贸易实务. 对外经济贸易大学出版社, 2013.

39. 刘晓惠.中国和墨西哥贸易关系的实证分析.国际贸易问题,2007

40. McHardy Reid David, Alethia Jiménez y Peter Rahmer: NAFTA, Mexico and the China Factor en Voices of Mexico No 76, 7-9/2006

41. Matthew Davis. Is China Mercantilist? National Bureau of Economic Research. Massachusetts. 2020.

42. Mesquita Moreira, Mauricio. Fear of China: Is There a Future for Manufacturing in Latin America. World Development, 2007.

43. Monje Avalos, Claudia Mayren. Evolución del Comercio en México a partir de la Entrada del Modelo Neoliberal, hasta la Firma del TLC con la Unión Europea. Tesis de Licenciatura. UNAM. México, 2010.

44. Montes, Juan. Mexico Finance Minister Bought House from Government Contractor. The Wall Street Journal. USA. December, 2014.

45. Naughton, B. China's Emergence and Prospects as a Trading Nation. Brookings Papers on Economic Activity, 1996(2), 273-344. 1996

46. Naughton, B. The Chinese Economy: Transitions and Growth, The MIT Press, Cambridge, MA. 2007.

47. Ojeda, Marcela. Becerril Isabel. Ven daño a relación México-China por Dragón Mart. El Financiero. México. Enero, 2015.

48. Oropeza García, Arturo. México-China. Culturas y sistemas jurídicos comparados. Universidad Nacional Autónoma de México/Instituto de Investigaciones Jurídicas, 2da edición. México 2016.

49. 秦艳敏, 刘屹. 中国与墨西哥对美国出口相似度研究 [J]. 特区经 济, 2010

50. Ramírez Gutiérrez, José Othón. Compensatory quotas with China: A learning case for Mexican trade. Virtual legal library of the Institute for Legal Research of the National Autonomous University of Mexico (UNAM).

51. Robert C. Feenstra and Hiau Looi Kee. Trade Liberalization and Export Variety: A Comparison of Mexico and China. The World Economy. 2007.

52. Rodrik D. What's So Special about China's Exports? China \& World Economy. 2006.

53. Roett, Riordan, and Guadalupe Paz. China's Expansion into the Western Hemisphere. Implications for Latin America and the United States. Brookings Institution Press. Washington, DC. 2008.

54. Romer Cornejo. México y la competitividad de China en Sergio Cesarin y Carlos Moneta (comps.): China y América Latina. Nuevos enfoques sobre cooperación y desarrollo. ¿Una segunda Ruta de la Seda?, Intal, Buenos Aires, 2005

55. 桑百川,李计广.拓展我国与主要新兴市场国家的贸易关系.财贸经 济,2011

56. Sánchez Olivares, Tania Selene. El Comercio Exterior de México. Universidad Nacional Autónoma de México. México. 2014

57. S.M Shafaeddin. Is China's Accession to WTO Threatening Exports of Developing Countries? China Economic Review, 2004.

58. Taboada Fontao, María Carmen. Un replanteamiento de la Teoría del Comercio Internacional desde la óptica tecnológica. 2014.

59. Zha, Daojiong, and Shaun Breslin. Oiling the Wheels of Foreign Policy? Energy Security and China's International Relations. Shaun Breslin ed., Handbook of China's International Relations. London, 2010 .

\section{WEBSITES REFERENCES}

Asia-Pacific Economic Cooperation, checked on $5^{\text {th }}$, February, 2020. https://www.apec.org

Chinese Knowledge Infrastructure Project, checked on 5 ${ }^{\text {th }}$, January, 2020. https://www.cnki.net/

Chinese Minister of Commerce, checked on $17^{\text {th }}$, January, 2020. http://www.mofcom.gov.cn

Daily China News, checked on $28^{\text {th }}$, February, 2020 https://www.chinadaily.com.cn

Embassy of the People's Republic of China in the United Mexican States; checked on $5^{\text {th }}$, January, 2020. http://mx.mofcom.gov.cn

International Trade Administration, checked on $20^{\text {th }}$, March, 2020 https://www.trade.gov

Published By:

Blue Eyes Intelligence Engineering

\& Sciences Publication 
Mexican Agro-food and fisheries information service; checked on 22th February, 2020. https://www.gob.mx/siap/documentos

Mexican Business Council for Foreign Trade, Investment and Technology, checked on $23^{\text {th }}$, January, 2020. http://www.comce.org.mx/

Mexican National Institute of Statistics and Geography, checked on $13^{\text {th }}$, April, 2020. https://www.inegi.org.mx

Mexican National Bank, checked on $9^{\text {th }}$, April, 2020 https://www.banxico.org.mx/

Mexican Ministry of Communications and Transportation, checked on $15^{\text {th }}$, March, 2020. http://www.sct.gob.mx

Mexican Ministry of Economy, checked on $10^{\text {th }}$, April, 2020. https://www.gob.mx/se

Minister of Foreign Affairs of the People's Republic of China; checked on $13^{\text {th }}$, February, 2020. https://www.fmprc.gov.cn/mfa eng

Mexican Ministry of Foreign Affairs; checked on $5^{\text {th }}$, April, 2020. https://embamex.sre.gob.mx

Mexican Presidency; checked on $26^{\text {th }}$, March, 2020 https://lopezobrador.org.mx

National Bureau of Statistics of China; checked on $10^{\text {th }}$, April, 2020. http://www.stats.gov.cn/

Office of the United States Trade Representative; checked on $3^{\text {rd }}$, April, 2020. https://ustr.gov/countries-regions/

United Nations Comtrade Database; checked on $8^{\text {th }}$ February, 2020 https://comtrade.un.org/

United Nations Conference on Trade and Development; checked on $29^{\text {th }}$, April, 2020. https://unctad.org

United States Census Bureau; checked on $19^{\text {th }}$ March, 2020. https://www.census.gov/

World Economic Forum; checked on 17 ${ }^{\text {th }}$ April, 2020 https://www.weforum.org/

World Bank; checked on 20 ${ }^{\text {th }}$, March, 2020. https://www.worldbank.org/ World Tourism Organization; checked on $16^{\text {th }}$ February, 2020. https://www.unwto.org/

World Trade Organization; checked on $18^{\text {th }}$, April, 2020. https://www.wto.org

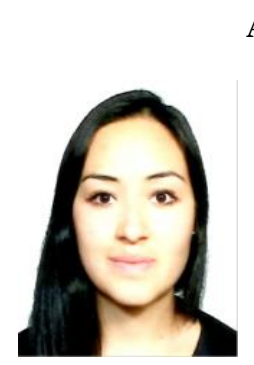

\section{ABOUT THE AUTHOR}

Paola Barrera Ibarra was born in Mexico City in February 1989. From 2007 to 2012, she studied a Law Degree at National Autonomous University of Mexico. From 2012 to 2013 studied Chinese Language at Shanghai International Studies University and from 2018 to 2020 studied a Master Degree at Yangtze University in China. She can speak Spanish, English, Chinese and Portuguese. Since 2010 she has worked as a lawyer in private Mexican and Chinese's law firms, such as Business Planes Solutions, S.C. de R.L. de C.V located in Mexico City; OBM Asia, S.A. de C.V. located in Brazil Sao Paulo and Huawei Technologies de Mexico, S.A. de C.V. In China she has participate in different events supporting Mexico and China relationship.

Email address: barrera.paola@qq.com 